\title{
Dietary calcium and body weight regulation
}

Citation for published version (APA):

Boon, N. (2007). Dietary calcium and body weight regulation. [Doctoral Thesis, Maastricht University]. Universitaire Pers Maastricht. https://doi.org/10.26481/dis.20070606nb

Document status and date:

Published: 01/01/2007

DOI:

10.26481/dis.20070606nb

Document Version:

Publisher's PDF, also known as Version of record

\section{Please check the document version of this publication:}

- A submitted manuscript is the version of the article upon submission and before peer-review. There can be important differences between the submitted version and the official published version of record.

People interested in the research are advised to contact the author for the final version of the publication, or visit the DOI to the publisher's website.

- The final author version and the galley proof are versions of the publication after peer review.

- The final published version features the final layout of the paper including the volume, issue and page numbers.

Link to publication

\footnotetext{
General rights rights.

- You may freely distribute the URL identifying the publication in the public portal. please follow below link for the End User Agreement:

www.umlib.nl/taverne-license

Take down policy

If you believe that this document breaches copyright please contact us at:

repository@maastrichtuniversity.nl

providing details and we will investigate your claim.
}

Copyright and moral rights for the publications made accessible in the public portal are retained by the authors and/or other copyright owners and it is a condition of accessing publications that users recognise and abide by the legal requirements associated with these

- Users may download and print one copy of any publication from the public portal for the purpose of private study or research.

- You may not further distribute the material or use it for any profit-making activity or commercial gain

If the publication is distributed under the terms of Article $25 \mathrm{fa}$ of the Dutch Copyright Act, indicated by the "Taverne" license above, 


\section{Dietary calcium and body weight regulation}



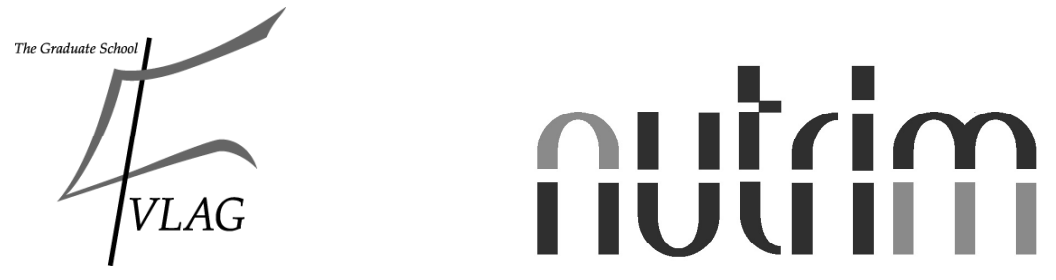

The studies presented in this thesis were performed at the Nutrition and Toxicology Research Institute Maastricht, which participaties in the Graduate School VLAG (Food Technology, Agrobiotechnology, Nutrition and Health Sciences), accredited by the Royal Netherlands Academy of Arts and Sciences.

Cover design: Eddy van Mourik

Layout: Niels Boon

Printed by: Datawyse

ISBN 978-90-5278-618-6

(C) Niels Boon 2007 


\section{Dietary calcium and body weight regulation}

\section{PROEFSCHRIFT}

Ter verkrijging van de graad van doctor aan de Universiteit Maastricht, op gezag van de Rector Magnificus, Prof. mr. G.P.M.F. Mols volgens het besluit van het College van Decanen, in het openbaar te verdedigen

op woensdag 6 juni 2007 om 16:00 uur

door

Niels Boon

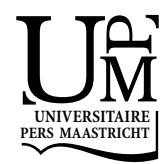




\section{Promotor:}

Prof. dr. ir. Wim H.M. Saris

\section{Beoordelingscommissie:}

Prof. dr. R.P. Mensink, voorzitter

Prof. dr. A.A. Masclee

Dr. R. Van der Meer (NIZO Food Research)

Dr. J.M. Steijns (Nutrition Affairs, Campina International, Wageningen)

Prof. dr. M. Westerterp-Plantenga

The research described in this thesis was supported by a grant of the Dutch Dairy Association

Financial support by the Dutch Dairy Council and the Unilever Food and Health Research Institute for the publication of this thesis is gratefully acknowledged. 


\section{Chapter 1:}

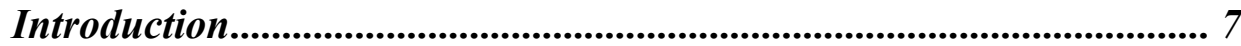

Chapter 2:

The Relation between Calcium Intake and Body Composition in a Dutch Population: The Amsterdam Growth and Health Longitudinal

Study

\section{Chapter 3:}

Dietary macronutrient distribution in relation to energy intake and body fatness

Chapter 4:

The effects of three diets with various calcium contents on 24-hour energy-expenditure, fat oxidation and adipose tissue $m R N A$ expression of lipid-metabolism related proteins.

\section{Chapter 5:}

The effects of increasing serum calcitriol on energy and fat metabolism

Chapter 6:

The effects of hydralazine on lipolysis in subcutaneous adipose tissue in humans.

Chapter 7:

An intervention study of the effects of calcium intake on faecal fat excretion, energy metabolism and adipose tissue $m R N A$ expression of lipid-metabolism related proteins

Chapter 8:

Postprandial plasma amino acid profiles in relation to markers of satiety.

Chapter 9:

General discussion

Samenvatting. 


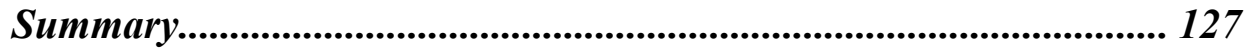

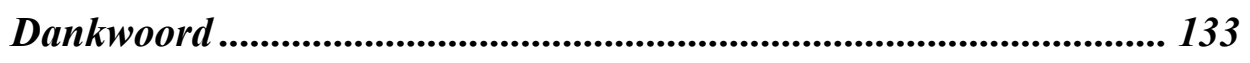

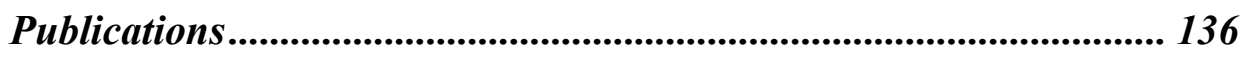

Curriculum Vitae ......................................................................... 138 


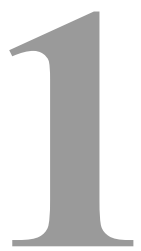

Introduction 


\section{The obesity epidemic}

Obesity is a chronic disease, characterized by an excessive storage of body fat and is associated with many other illnesses, such as insulin resistance and different cardiovascular diseases. It is directly related to an increased mortality and a lower life expectancy.

The WHO has designated five different classes of overweight and obesity, identified by different values of the Body Mass Index (BMI). At a BMI of $25-30 \mathrm{~kg} / \mathrm{m}^{2}$, one is considered overweight, a BMI of 30-35 is also called class I obesity, an individual with a BMI of 35-40 suffers from class II obesity and at a BMI of $40 \mathrm{~kg} / \mathrm{m}^{2}$ or more, one is considered very severely or class III obese (1). The prevalence of obesity has increased markedly during the past decades, both on a global (1) as well as on a national level (2). It has been estimated that around $40 \%$ of the Dutch adult population is overweight and that the prevalence of obesity in The Netherlands is about $10 \%$. These values have increased during the last 2 decades, despite a reduction in total fat and energy intake (2). However, both in Europe as well as in the US, the availability (but not necessarily the consumption) of energy and fat from food has increased during the same time period by about $25 \%$ (1). Obesity is a very important risk factor for the development of a number of chronic disorders, such as cardiovascular disease and diabetes (3-5).

Bluntly stated, obesity is caused by an imbalance of energy expenditure (EE) through physical activity and energy intake from food. It has indeed been observed that overall physical activity has decreased over the years in the Netherlands (2) and physical activity has been identified as a very important determinant of energy expenditure, which means that overall EE may also have gone down (6).

When it comes to food intake, an increased intake of macronutrients and therefore an increased energy intake is obviously the most important factor causing the imbalance between energy intake and energy expenditure (7), but the role of specific micronutrients and food groups in the development of obesity has also been acknowledged during recent years. Important examples of these micronutrients and food groups are calcium and dairy foods, respectively (8-11). After the first publication of epidemiological results by McCarron et al in 1984 (12) and the publication by Zemel et al. in 1998 (8), in which a possible mechanism to explain this unexpected inverse association between calcium intake and body weight was postulated, the relation between calcium and dairy intake and obesity has been studied extensively in many animal and cell culture models (13-24), randomized clinical trials (25-31) and many observational investigations (32-46).

\section{The first indications of an association between calcium intake and body composition: epidemiological investigations.}

After the unexpected observation of an inverse association between calcium intake and body weight in a study designed to look at the relation between dietary calcium and blood pressure by McCarron in 1984 (12), many observational investigations have been published about the association of calcium and/or dairy intake and body weight. Different types of populations were studied; children, adolescents, young men and 
women and the elderly. In most of these investigations, the relation between calcium and body weight was specifically addressed, whereas in some others, the impact of dairy intake on body weight was studied. Another discrepancy in design between the different investigations is that in some, dietary protein intake, which has been shown to have weight lowering effects (47-51), was included in the analyses as a confounder, whereas in others this was not the case. In this section, the results of these investigations will be discussed. They are also displayed schematically in table 1 .

In this table, there are 8 studies investigating the effects of calcium and dairy intake in children $(<16 \mathrm{yr})$. All but one of these investigations were carried out in the United States $(34,42-44,46,52,53)$, the other one was performed in Italy (33). The calcium intakes were around $700 \mathrm{mg} /$ day and in only one of the experiments, statistical corrections for the confounding effects of the dietary protein intake were performed (43). Interestingly, this was one of the three studies in which no effects of dairy or calcium intake on body weight were seen. In the other studies in which no effects of calcium and dairy intake were observed, either the study population was genetically predisposed to obesity (46) or the effects of calcium and dairy products were specifically addressed (53). The authors of the first study hypothesized that the high intake of fat and energy in their study population counteracted the effects of calcium (46). Because it has been proposed that other dairy components, apart from calcium, may also exert anti-obesity effects, this may have changed the results of the other study (53).

Four of these observational investigations looked at the relation of calcium intake and body weight in women $(37,40,54,55)$ and only in the meta-analysis of Heaney et al. (37), corrections for protein intake were done. Although both the average age and the average calcium intake of the study populations showed a rather large variation among these studies, these differences did not affect the association of calcium and dairy intake and body composition, i.e. in all of these studies, an inverse relation of calcium and body weight was observed.

Furthermore, in one investigation from the US, the relation between calcium intake and body composition was studied in a population of $63 \mathrm{yr}$ old men (56). In this study, the average calcium intake was around $1000 \mathrm{mg} /$ day, no corrections were made for protein intake and an inverse relation of calcium with body weight was observed. In a recent publication, Rajpathak et al. did not find an association between dairy or calcium intake and body weight in middle aged men (57).

To date, five studies have also been published investigating this association in a mixed population of both male and female adults. The results from these studies are controversial. In the investigation by Jacqmain et al, no effects were observed in Canadian men with an average calcium consumption of $1016 \mathrm{mg} / \mathrm{day}$, but in females (with a calcium consumption that was about $150 \mathrm{mg}$ lower), an inverse relation of calcium with body weight was observed (38). In the cross-sectional study by Kamycheva et al., a positive relation was observed in Norwegian men and no association was seen in women. The average calcium consumption was low in this population with 541 and $437 \mathrm{mg} /$ day for the men and women, respectively. Similar to the study of Jacqmain, no corrections were made for the confounding effects of protein intake (39). In their study population from the US, Loos et al. observed negative associations for black and white males and white females, but no association in black females. Calcium intakes ranged from 737 to $1098 \mathrm{mg}$ and the confounding effects of the increased protein intake that could be associated with an increased dairy intake were taken into account in this investigation (41). In the Iranian Tehran Lipid and Glucose 
Table 1: An overview of the epidemiological studies looking at the association between calcium and dairy intake on body composition.

\begin{tabular}{|c|c|c|c|c|c|c|c|}
\hline & Subjects & Study Design & Country & $\begin{array}{c}\text { Relation } \\
\text { dairy } / \mathrm{Ca}^{2+} \\
\text { and body } \\
\text { weight }\end{array}$ & $\begin{array}{c}\text { Correction } \\
\text { for protein } \\
\text { intake? }\end{array}$ & $\begin{array}{c}\text { Habitual } \\
\mathrm{Ca}^{2+} \text {-intake }\end{array}$ & $\begin{array}{c}\text { Independent } \\
\text { Variable } \\
\mathrm{C}=\text { Calcium } \\
\mathrm{D}=\text { Dairy }\end{array}$ \\
\hline \multirow[t]{2}{*}{$\begin{array}{l}\text { Buchowski } 2002 \\
\text { (54) }\end{array}$} & $\begin{array}{c}57 \text { Premenopausal African American } \\
\text { Women }\end{array}$ & Study of lactose intolerance & US & - & No & $780 \pm 305\left(\mathrm{LT}^{*}\right)$ & $\mathrm{C}$ \\
\hline & & & & & & $388 \pm 151\left(\mathrm{LI}^{*}\right)$ & \\
\hline Carruth 2001 (52) & 53 children, $2-5 y$ & Longitudinal & US & - & No & $700-1000$ & $\mathrm{C}$ \\
\hline Heaney 2003 (37) & 384 young and 216 middle-aged women & $\begin{array}{c}\text { Re-analysis of data from Davies } \\
\text { et al. }\end{array}$ & US & - & Yes & $500-1300$ & $\mathrm{C}$ \\
\hline \multirow[t]{2}{*}{ Jacqmain 2003 (38) } & 235 men and 235 women & $\begin{array}{c}\text { Cross-sectional Québec Family } \\
\text { Study }\end{array}$ & US & $=(\mathrm{M})$ & Yes & & $\mathrm{C}$ \\
\hline & & & & $-(W)$ & & $861 \pm 23(W)$ & \\
\hline \multirow[t]{2}{*}{$\begin{array}{l}\text { Kamycheva } 2003 \\
(39)\end{array}$} & 9252 Men and 9662 Women & $\begin{array}{l}\text { Cross-sectional } \\
\text { Tromsø Study }\end{array}$ & Norway & $+(\mathrm{M})$ & No & & $\mathrm{C}$ \\
\hline & & & & $=(\mathrm{W})$ & & $437 \pm 2(W)$ & \\
\hline Lin $2000(40)$ & $\begin{array}{l}54 \text { Women; } \\
18-31 \mathrm{yr}\end{array}$ & $2 \mathrm{yr}$ activity intervention & US & - & No & $781 \pm 212$ & $\mathrm{C}$ \\
\hline \multirow[t]{4}{*}{ Loos 2004 (41) } & $\begin{array}{l}362 \text { Men and } \\
462 \text { Women }\end{array}$ & $\begin{array}{c}\text { Cross-sectional } \\
\text { Heritage Family Study }\end{array}$ & US & $\begin{array}{l}\text {-(black } \\
\text { M) }\end{array}$ & Yes & & $\mathrm{C}$ \\
\hline & & & & $\begin{array}{l}\text {-(white } \\
\text { M) }\end{array}$ & & $1098 \pm 38$ & \\
\hline & & & & & & $825 \pm 42$ & \\
\hline & & & & $\begin{array}{c}-(\text { white } \\
\text { W) }\end{array}$ & & $1060 \pm 34$ & \\
\hline Novotny 2004 (42) & $\begin{array}{l}323 \mathrm{Girls} \\
9-14 \mathrm{yr}\end{array}$ & Cross-sectional & US & - & No & $737 \pm 371$ & $\mathrm{C}$ \\
\hline Philips 2003 (43) & $\begin{array}{l}178 \text { Non-obese } \\
\text { meisjes; } 8-12 \text { yr }\end{array}$ & $\begin{array}{l}\text { MIT Growth and } \\
\text { Development Study }\end{array}$ & US & $=$ & Yes & $\begin{array}{l}808 \pm 400 \text { (start) } \\
659 \pm 432(\text { end })\end{array}$ & $\mathrm{D}$ \\
\hline Skinner 2003 (44) & 52 Children $8 \mathrm{yr}$ & Prospective & US & - & No & $767-1028$ & $\mathrm{C}$ \\
\hline \multirow[t]{2}{*}{ Boon 2005 (35) } & Longitudinal: 629 boys and girls $13-36 \mathrm{yr}$. & $\begin{array}{l}\text { Prospective Amsterdam Growth } \\
\text { and Health Longitudinal Study }\end{array}$ & NL & $-/=$ & No & $1273(\mathrm{M})$ & $\mathrm{C}$ \\
\hline & & & & & & $1072(\mathrm{~W})$ & \\
\hline Azadbakht 2005 (32) & $\begin{array}{l}357 \text { men and } \\
470 \text { women }\end{array}$ & Tehran Lipid and Glucose Study & Iran & $-/-$ & Yes & 945 & $\mathrm{D}$ \\
\hline \multirow[t]{2}{*}{ Berkey 2005 (34) } & 5550 boys and 7279 girls $9-14 \mathrm{yr}$ & Growing up today & US & $+/+$ & No & $1291(\mathrm{M})$ & D\&C \\
\hline & & & & & & $1145(\mathrm{~F})$ & \\
\hline Venti 2005 (46) & $\begin{array}{l}35 \text { men } / 30 \text { women } \\
36 \text { boys } / 42 \text { girls }\end{array}$ & Pima Indians & US & $=1=$ & No & $\begin{array}{l}876 \pm 336 / 974 \pm 345 \\
663 \pm 403 / 614 \pm 304\end{array}$ & $\mathrm{C}$ \\
\hline Rosell 2004 (56) & 30163 yr. old men & & US & - & No & $1000 \pm 200$ & $\mathrm{C}$ \\
\hline Barba 2005 (33) & 451 boys and 433 girls, average age $7.5 \mathrm{yr}$. & & Italy & - & No & & $\mathrm{D}$ \\
\hline Rajpathak 2006 (57) & 23054 men aged $40-75 \mathrm{yr}$. & Health Professionals study & US & $=$ & Yes & $\begin{array}{l}799 \text { (start) } \\
891 \pm \text { (end) }\end{array}$ & D\&C \\
\hline
\end{tabular}


Study, an inverse association between dairy intake and body weight was observed in both men and women with an average calcium intake of $945 \mathrm{mg} /$ day. No corrections for protein intake were done in this study (32).

Summarizing the observations in these investigations, it seems like the effects of calcium and dairy intake are larger in populations with a low habitual calcium intake, such as in the United States. Therefore, it is likely that less pronounced effects will be observed in a population with a higher habitual calcium intake, such as in The Netherlands. Furthermore, the confounding effects of the higher dietary protein intake that is secondary to a high dairy intake may explain a part of the inverse association between calcium and body weight.

\section{A possible explanation for these observations: Changes in serum $1,25-\mathrm{OH}_{2} \mathrm{D}_{3}$}

A hypothesis to explain the inverse association of calcium with body weight noted in some of the observational studies was postulated by Zemel et al. (29); Decreasing the concentration of $1,25-\mathrm{OH}_{2} \mathrm{D}_{3}$ in cultures of human adipocytes and in transgenic mice caused acute decreases of the intracellular calcium concentration in adipocytes $(19,22)$. This could decrease lipogenesis through a $\mathrm{Ca} 2+$-dependent inhibition of fatty acid synthase (FAS) expression and increase lipolysis through a $\mathrm{Ca} 2+$-dependent inhibition of phosphodiesterase $3 \mathrm{~b}$ and an increase in the cAMP concentration. The latter increases the phosphorylation of hormone sensitive lipase thus increasing the rate of lipolysis $(8$, $10,21,23)$. In this way, a high dietary calcium intake may lead to a lower body weight by changing the rate of lipolysis and lipogenesis in adipose tissue through a decrease in serum $1,25-\mathrm{OH}_{2} \mathrm{D}_{3}(8)$. (Figure 1) Furthermore, $1,25-\mathrm{OH}_{2} \mathrm{D}_{3}$ is an important regulator of a large number of genes (58). Among the genes $1,25-\mathrm{OH}_{2} \mathrm{D}_{3}$ are also genes that are either related to fat breakdown and storage ( $H S L$ (hormone sensitive lipase), $G P D H_{2}$ (glycerol phosphate dehydrogenase), FAS (fatty acid synthase)) or adipocyte differentiation (PPAR $\gamma$ (peroxisome proliferator activated receptor gamma)) $(15,59-$ 62). Furthermore, $1,25-\mathrm{OH}_{2} \mathrm{D}_{3}$ decreases the mRNA expression of $U C P_{2}(16)$, which is correlated with basal metabolic rate (59).

So according to this hypothesis, changes in calcium intake will induce differences in adipocyte calcium homeostasis, which in turn leads to changes in fat metabolism and mRNA expression of genes related to fat metabolism.

\section{Dietary calcium and intestinal fat absorption: Effects on body weight}

An increased calcium intake could lead to an increased calcium concentration in the intestine, which in turn causes an increased binding of fatty acids and bile acids. This leads to the formation of insoluble calcium-fatty acid soaps, which are excreted through the faeces. This decreases the delivery of fat to the systemic circulation. It has also been proposed that calcium binds more avidly to saturated fatty acids, so a relative increase in the excretion of saturated fatty acids could also be expected (63). An increased faecal fat excretion as a result of an increased calcium intake has been observed previously in a number of investigations and in these studies, the magnitude of the effect was small but significant with increases in the order of up to $4 \mathrm{~g}$ /day $(63,64)$. 


\section{Chapter 1}

Figure 1: A schematic representation of the Zemel hypothesis. This hypothesis is based on the assumptions that dietary calcium intake is inversely related to the serum calcitriol $\left(1,25-\mathrm{OH}_{2}-\mathrm{D}_{3}\right)$ concentration and that calcitriol facilitates the influx of calcium ions into adipocytes. An increase in the dietary calcium intake could decrease the intracellular calcium concentration, which will in turn increase lipolysis and decrease lipogenesis. Furthermore, decreases in calcitriol may also increase transcription of $\mathrm{UCP}_{2} \mathrm{mRNA}$, which in turn could increase basal metabolic rate.

\section{Increased dietary}

\section{$\mathrm{Ca}^{2+}$ intake}

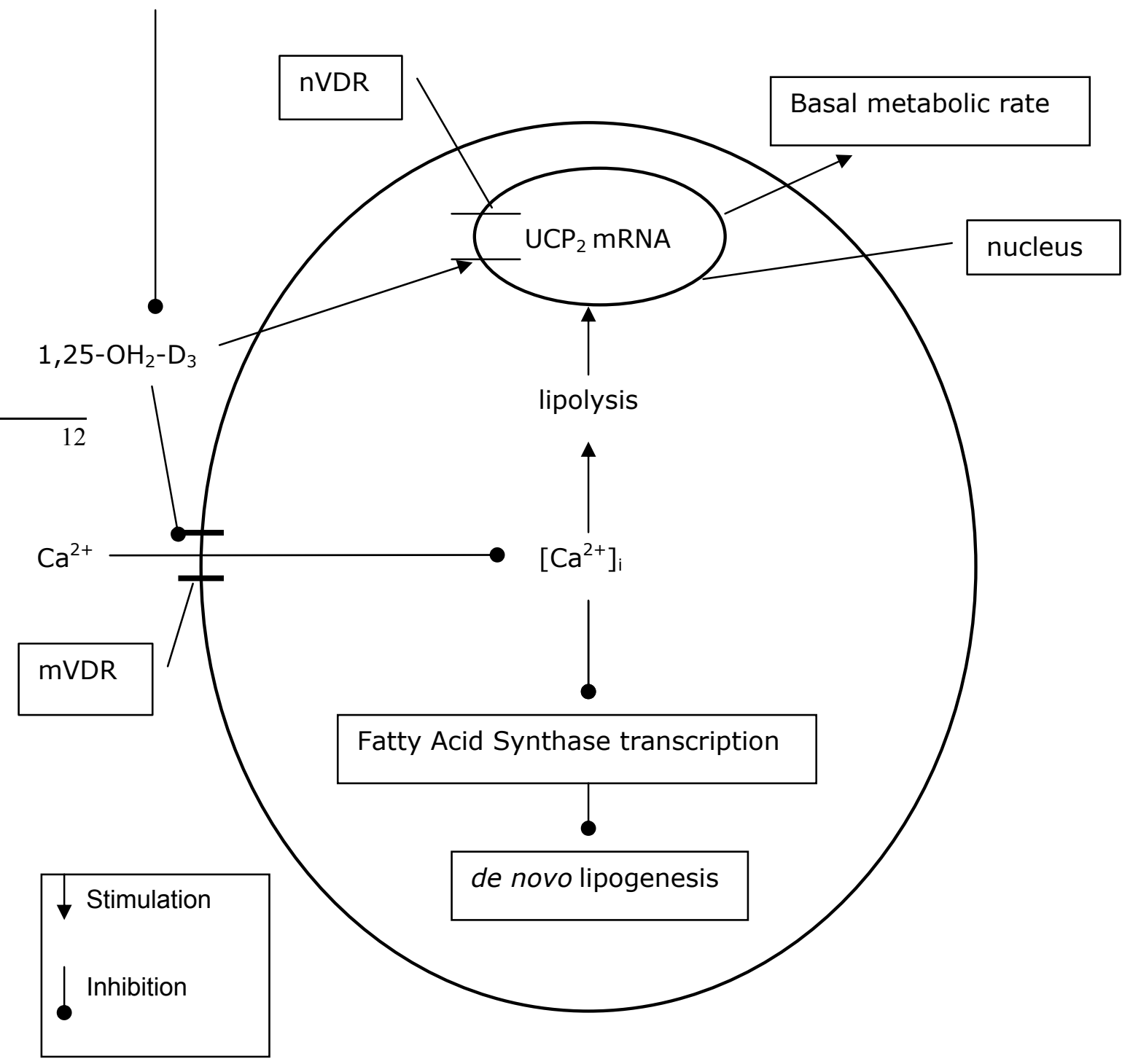




\section{Anti-obesity effects of (dairy) protein}

Apart from calcium, protein is another component of dairy that could affect body weight. A high dairy intake could be related to an increased protein intake (41). Protein is known to induce a higher diet induced thermogenesis (DIT) per kilojoule than fats or carbohydrates leading to a lower metabolic efficiency per kilojoule intake. The synthesis of peptide bonds, production of urea and gluconeogenesis are all metabolic processes with a high energy requirement that are elevated by consumption of a high protein diet $(65,66)$. The increased DIT due to an increased protein consumption has been confirmed in a number of clinical trials $(65,67,68)$.

In addition, an increased satiety has been reported in subjects on high protein diets (6971). Although the mechanisms that are responsible for this relation are not exactly understood, it has been reported that the increased satiety is correlated to the elevated DIT, which leads to an increased core temperature (71). In rodents, the increased satiety that is observed in response to a high protein diet has also been linked to an increased cholecystokinine production (72).

A high consumption of dairy could also have positive effects on weight control through changes in postprandial fat and energy metabolism. In a number of investigations, a smaller decline of the postprandial fat oxidation was observed in response to meals with a high calcium and/or dairy content $(26,73-75)$. This might be caused by a reduced fat absorption from the gut due to the fat binding capacity of calcium, which could cause a negative energy balance (76). However, a negative energy balance is not expected immediately after a meal so a more likely explanation is that the high concentration of branched chain amino acids (BCAAs) in particular from whey protein has favorable effects on postprandial fat and energy metabolism for example by increasing the sensitivity of muscle protein synthesis to insulin and by increasing the availability of dietary nitrogen to peripheral tissues (77-79). This increase in lean body mass has a positive effect on body weight control.

As was noted in the previous section, protein is a macronutrient that could have several positive effects on body weight. Therefore, it has been used in studies on body weight regulation (47-51). In an intervention study by Skov et al. subjects received an ad libitum diet with a reduced fat concentration, it was observed that subjects receiving a high protein diet lost significantly more body weight than the group receiving a diet with a normal protein-high carbohydrate level (51). In obese subjects who had lost weight after a 4-week very low energy diet, Westerterp-Plantenga et al. observed that the addition of a protein supplement ( $3 \%$ of the total energy intake) to the diet resulted in a smaller body weight regain when compared to a control group that did not receive the protein supplement (71). These trials show that an increase in protein intake may affect body weight in subjects consuming an ad libitum or isocaloric diet, at least during and after weight loss. Possible mechanisms for this increased weight loss are a better conservation of lean mass and an increased satiety.

\section{Outline of the thesis}

This thesis gives an overview of a number of different investigations, in which we have studied various aspects of the role of calcium and dairy products in obesity. In Chapter $\mathbf{2}$, the results of a re-analysis of data from the Amsterdam Growth and Health 
Longitudinal Study are presented. In Chapter 3 a more detailed analysis is reported about the role of dietary protein intake coming form dairy or other sources and body composition in the same cohort. In the next series of studies we have focused on the Zemel theory and we look at the different metabolic steps in this theory. In Chapter 4, we describe the results of a randomized clinical trial, in which we studied the effects of different diets with different calcium concentrations on energy and substrate metabolism and adipose tissue mRNA expression of proteins related to fat metabolism. To study the effects of changes in serum $1,25-\mathrm{OH}_{2} \mathrm{D}_{3}$ in further detail, the investigation that is described in chapter 5 was carried out. In this experiment, we induced significant changes in the serum $1,25-\mathrm{OH}_{2} \mathrm{D}_{3}$ concentration through oral supplementation, in order to look at the effects on energy and substrate metabolism or adipose tissue mRNA expression. In chapter 6, we present the results of a microdialysis study, in which we have investigated the effects of altering the intracellular calcium concentration in fat cells on lipolysis. During our research on the role of calcium the paper of Jacobsen et al. was published showing the effect of calcium on fat binding in the intestine. Since we had not collected faeces in our first controlled intervention trial we decided to set up a second well controlled intervention trial with a focus on the effect of calcium on fat binding. In chapter 7, the results of this randomized clinical trial investigating the effects of dietary calcium intake on faecal energy and fat excretion, energy and substrate metabolism and adipose tissue mRNA expression are described. Because some recent papers have shown that dairy intake could alter the postprandial metabolic response and that they may also have effects on satiety and that these effects could be linked to the high BCAA concentration in dairy protein, chapter 8 deals with the effects of different meal challenges on postprandial plasma BCAA concentrations.

Finally, in chapter 9, in a general discussion all results are evaluated and discussed given the published results in this field so far. Furthermore an overview of the main conclusions is given and directions for future research are given. 


\section{References}

1. WHO. Diet, nutrition and the prevention of chronic diseases. 2003.

2. Kemper HC, Stasse-Wolthuis M, Bosman W. The prevention and treatment of overweight and obesity. Summary of the advisory report by the Health Council of The Netherlands. Neth J Med 2004;62:10-7.

3. Anderwald C, Roden M. Adipotoxicity and the insulin resistance syndrome. Pediatr Endocrinol Rev 2004;1:310-9.

4. Lakka HM, Laaksonen DE, Lakka TA, et al. The metabolic syndrome and total and cardiovascular disease mortality in middle-aged men. Jama 2002;288:2709-16.

5. Sullivan PW, Morrato EH, Ghushchyan V, Wyatt HR, Hill JO. Obesity, inactivity, and the prevalence of diabetes and diabetes-related cardiovascular comorbidities in the U.S., 2000-2002. Diabetes Care 2005;28:1599-603.

6. Westerterp KR. Alterations in energy balance with exercise. Am J Clin Nutr 1998;68:970S-974S.

7. Nielsen SJ, Popkin BM. Patterns and trends in food portion sizes, 1977-1998. Jama 2003;289:4503.

8. Zemel MB. Nutritional and endocrine modulation of intracellular calcium: implications in obesity, insulin resistance and hypertension. Mol Cell Biochem 1998;188:129-36.

9. Zemel MB. Calcium modulation of hypertension and obesity: mechanisms and implications. J Am Coll Nutr 2001;20:428S-435S; discussion 440S-442S.

10. Zemel MB. Mechanisms of dairy modulation of adiposity. J Nutr 2003;133:252S-256S.

11. Zemel MB, Shi H, Greer B, Dirienzo D, Zemel PC. Regulation of adiposity by dietary calcium. Faseb J 2000;14:1132-8.

12. McCarron DA. Dietary calcium as an antihypertensive agent. Nutr Rev 1984;42:223-5.

13. Shi H, Dirienzo D, Zemel MB. Effects of dietary calcium on adipocyte lipid metabolism and body weight regulation in energy-restricted aP2-agouti transgenic mice. Faseb J 2001;15:291-3.

14. Shi H, Halvorsen YD, Ellis PN, Wilkison WO, Zemel MB. Role of intracellular calcium in human adipocyte differentiation. Physiol Genomics 2000;3:75-82.

15. Shi H, Norman AW, Okamura WH, Sen A, Zemel MB. 1alpha,25-Dihydroxyvitamin D3 modulates human adipocyte metabolism via nongenomic action. Faseb J 2001;15:2751-3.

16. Shi H, Norman AW, Okamura WH, Sen A, Zemel MB. 1alpha,25-dihydroxyvitamin D3 inhibits uncoupling protein 2 expression in human adipocytes. Faseb J 2002;16:1808-10.

17. Sun X, Zemel MB. Effects of mitochondrial uncoupling on adipocyte intracellular $\mathrm{Ca}(2+)$ and lipid metabolism. J Nutr Biochem 2003;14:219-26.

18. Sun X, Zemel MB. Role of uncoupling protein 2 (UCP2) expression and 1alfa,25dihydroxyvitamin D3 in modulating adipocyte apoptosis. NAASO, 2003.

19. Sun X, Zemel MB. Calcium and Dairy Products Inhibit Weight and Fat Regain during Ad Libitum Consumption Following Energy Restriction in Ap2-Agouti Transgenic Mice. J Nutr 2004;134:3054-60.

20. Sun X, Zemel MB. Role of uncoupling protein 2 (UCP2) expression and 1alpha, 25 dihydroxyvitamin D3 in modulating adipocyte apoptosis. Faseb J 2004.

21. Xue B, Greenberg AG, Kraemer FB, Zemel MB. Mechanism of intracellular calcium ([Ca2+]i) inhibition of lipolysis in human adipocytes. Faseb J 2001;15:2527-9.

22. Xue B, Moustaid N, Wilkison WO, Zemel MB. The agouti gene product inhibits lipolysis in human adipocytes via a Ca2+-dependent mechanism. Faseb J 1998;12:1391-6.

23. Xue B, Zemel MB. Relationship between human adipose tissue agouti and fatty acid synthase (FAS). J Nutr 2000;130:2478-81

24. Zemel MB. Effects of calcium-fortified breakfast cereal on adiposity in a transgenic mouse model of obesity. Faseb J 2001:598 (abstr.).

25. Jacobsen R, Lorenzen JK, Toubro S, Krog-Mikkelsen I, Astrup A. Effect of short-term high dietary calcium intake on 24-h energy expenditure, fat oxidation, and faecal fat excretion. Int J Obes Relat Metab Disord 2005;29:292-301.

26. Melanson EL, Donahoo WT, Dong F, Ida T, Zemel MB. Effect of low- and high-calcium dairybased diets on macronutrient oxidation in humans. Obes Res 2005;13:2102-12.

27. Melanson EL, Sharp TA, Schneider J, Donahoo WT, Grunwald GK, Hill JO. Relation between calcium intake and fat oxidation in adult humans. Int J Obes Relat Metab Disord 2003;27:196-203. 
28. Thompson WG, Rostad Holdman N, Janzow DJ, Slezak JM, Morris KL, Zemel MB. Effect of energy-reduced diets high in dairy products and fiber on weight loss in obese adults. Obes Res 2005;13:1344-53.

29. Zemel MB. Role of calcium and dairy products in energy partitioning and weight management. Am J Clin Nutr 2004;79:907S-12S.

30. Zemel MB, Richards J, Mathis S, Milstead A, Gebhardt L, Silva E. Dairy augmentation of total and central fat loss in obese subjects. Int J Obes Relat Metab Disord 2005.

31. Zemel MB, Thompson W, Milstead A, Morris K, Campbell P. Calcium and Dairy Acceleration of Weight and Fat Loss during Energy Restriction in Obese Adults. Obes Res 2004;12:582-90.

32. Azadbakht L, Mirmiran P, Esmaillzadeh A, Azizi F. Dairy consumption is inversely associated with the prevalence of the metabolic syndrome in Tehranian adults. Am J Clin Nutr 2005;82:52330 .

33. Barba G, Troiano E, Russo P, Venezia A, Siani A. Inverse association between body mass and frequency of milk consumption in children. Br J Nutr 2005;93:15-9.

34. Berkey CS, Rockett HR, Willett WC, Colditz GA. Milk, dairy fat, dietary calcium, and weight gain: a longitudinal study of adolescents. Arch Pediatr Adolesc Med 2005; 159:543-50.

35. Boon N, Koppes LL, Saris WH, Van Mechelen W. The Relation between Calcium Intake and Body Composition in a Dutch Population: The Amsterdam Growth and Health Longitudinal Study. Am J Epidemiol 2005;162:27-32.

36. Davies KM, Heaney RP, Recker RR, et al. Calcium intake and body weight. J Clin Endocrinol Metab 2000;85:4635-8.

37. Heaney RP. Normalizing calcium intake: projected population effects for body weight. J Nutr 2003;133:268S-270S.

38. Jacqmain M, Doucet E, Despres JP, Bouchard C, Tremblay A. Calcium intake, body composition, and lipoprotein-lipid concentrations in adults. Am J Clin Nutr 2003;77:1448-52.

39. Kamycheva E, Joakimsen RM, Jorde R. Intakes of calcium and vitamin d predict body mass index in the population of Northern Norway. J Nutr 2003;133:102-6.

40. Lin YC, Lyle RM, McCabe LD, McCabe GP, Weaver CM, Teegarden D. Dairy calcium is related to changes in body composition during a two-year exercise intervention in young women. $\mathrm{J}$ Am Coll Nutr 2000;19:754-60.

41. Loos RJ, Rankinen T, Leon AS, et al. Calcium Intake Is Associated with Adiposity in Black and White Men and White Women of the HERITAGE Family Study. J Nutr 2004;134:1772-1778. Novotny R. Dairy, calcium and body composition of multiethnic youth. Asia Pac J Clin Nutr 2004;13:S36 (abstr.).

43. Phillips SM, Bandini LG, Cyr H, Colclough-Douglas S, Naumova E, Must A. Dairy food consumption and body weight and fatness studied longitudinally over the adolescent period. Int $\mathrm{J}$ Obes Relat Metab Disord 2003;27:1106-13.

44. Skinner JD, Bounds W, Carruth BR, Ziegler P. Longitudinal calcium intake is negatively related to children's body fat indexes. J Am Diet Assoc 2003;103:1626-31.

45. Teegarden D. Calcium intake and reduction in weight or fat mass. J Nutr 2003;133:249S-251S.

46. Venti CA, Tataranni PA, Salbe AD. Lack of Relationship between Calcium Intake and Body Size in an Obesity-Prone Population. J Am Diet Assoc 2005;105:1401-7.

47. Baba NH, Sawaya S, Torbay N, Habbal Z, Azar S, Hashim SA. High protein vs high carbohydrate hypoenergetic diet for the treatment of obese hyperinsulinemic subjects. Int J Obes Relat Metab Disord 1999;23:1202-6.

48. Eisenstein J, Roberts SB, Dallal G, Saltzman E. High-protein weight-loss diets: are they safe and do they work? A review of the experimental and epidemiologic data. Nutr Rev 2002;60:189-200.

49. Farnsworth E, Luscombe ND, Noakes M, Wittert G, Argyiou E, Clifton PM. Effect of a highprotein, energy-restricted diet on body composition, glycemic control, and lipid concentrations in overweight and obese hyperinsulinemic men and women. Am J Clin Nutr 2003;78:31-9.

50. Whitehead JM, McNeill G, Smith JS. The effect of protein intake on 24-h energy expenditure during energy restriction. Int J Obes Relat Metab Disord 1996;20:727-32.

51. Skov AR, Toubro S, Ronn B, Holm L, Astrup A. Randomized trial on protein vs carbohydrate in ad libitum fat reduced diet for the treatment of obesity. Int $\mathrm{J}$ Obes Relat Metab Disord 1999;23:528-36.

52. Carruth BR, Skinner JD. The role of dietary calcium and other nutrients in moderating body fat in preschool children. Int J Obes Relat Metab Disord 2001;25:559-66.

53. Dixon LB, Pellizzon MA, Jawad AF, Tershakovec AM. Calcium and dairy intake and measures of obesity in hyper- and normocholesterolemic children. Obes Res 2005;13:1727-38.

54. Buchowski MS, Semenya J, Johnson AO. Dietary calcium intake in lactose maldigesting intolerant and tolerant African-American women. J Am Coll Nutr 2002;21:47-54. 
55. Liu S, Song Y, Ford ES, Manson JE, Buring JE, Ridker PM. Dietary calcium, vitamin D, and the prevalence of metabolic syndrome in middle-aged and older U.S. women. Diabetes Care 2005;28:2926-32.

56. Rosell M, Johansson G, Berglund L, Vessby B, de Faire U, Hellenius ML. Associations between the intake of dairy fat and calcium and abdominal obesity. Int J Obes Relat Metab Disord 2004;28:1427-34.

57. Rajpathak SN, Rimm EB, Rosner B, Willett WC, Hu FB. Calcium and dairy intakes in relation to long-term weight gain in US men. Am J Clin Nutr 2006;83:559-66.

58. DeLuca HF, Zierold C. Mechanisms and functions of vitamin D. Nutr Rev 1998;56:S4-10; discussion S 54-75.

59. Barbe P, Millet L, Larrouy D, et al. Uncoupling protein-2 messenger ribonucleic acid expression during very-low-calorie diet in obese premenopausal women. J Clin Endocrinol Metab 1998;83:2450-3.

60. Duque G, Macoritto M, Kremer R. 1,25(OH)2D3 inhibits bone marrow adipogenesis in senescence accelerated mice (SAM-P/6) by decreasing the expression of peroxisome proliferator-activated receptor gamma 2 (PPARgamma2). Exp Gerontol 2004;39:333-8.

61. Hida Y, Kawada T, Kayahashi S, Ishihara T, Fushiki T. Counteraction of retinoic acid and 1,25dihydroxyvitamin D3 on up-regulation of adipocyte differentiation with PPARgamma ligand, an antidiabetic thiazolidinedione, in 3T3-L1 cells. Life Sci 1998;62:PL205-11.

62. Large V, Arner P, Reynisdottir S, et al. Hormone-sensitive lipase expression and activity in relation to lipolysis in human fat cells. J Lipid Res 1998;39:1688-95.

63. Welberg JW, Monkelbaan JF, de Vries EG, et al. Effects of supplemental dietary calcium on quantitative and qualitative faecal fat excretion in man. Ann Nutr Metab 1994;38:185-91.

64. Shahkhalili Y, Murset C, Meirim I, et al. Calcium supplementation of chocolate: effect on cocoa butter digestibility and blood lipids in humans. Am J Clin Nutr 2001;73:246-52.

65. Johnston CS, Day CS, Swan PD. Postprandial thermogenesis is increased 100\% on a high-protein, low-fat diet versus a high-carbohydrate, low-fat diet in healthy, young women. J Am Coll Nutr 2002;21:55-61.

66. Robinson SM, Jaccard C, Persaud C, Jackson AA, Jequier E, Schutz Y. Protein turnover and thermogenesis in response to high-protein and high-carbohydrate feeding in men. Am J Clin Nutr 1990;52:72-80.

67. Mikkelsen PB, Toubro S, Astrup A. Effect of fat-reduced diets on 24-h energy expenditure: comparisons between animal protein, vegetable protein, and carbohydrate. Am J Clin Nutr 2000;72:1135-41.

68. Westerterp KR, Wilson SA, Rolland V. Diet induced thermogenesis measured over 24h in a respiration chamber: effect of diet composition. Int J Obes Relat Metab Disord 1999;23:287-92.

69. Poppitt SD, McCormack D, Buffenstein R. Short-term effects of macronutrient preloads on appetite and energy intake in lean women. Physiol Behav 1998;64:279-85.

70. Stubbs RJ, van Wyk MC, Johnstone AM, Harbron CG. Breakfasts high in protein, fat or carbohydrate: effect on within-day appetite and energy balance. Eur J Clin Nutr 1996;50:409-17.

71. Westerterp-Plantenga MS, Lejeune MP, Nijs I, van Ooijen M, Kovacs EM. High protein intake sustains weight maintenance after body weight loss in humans. Int J Obes Relat Metab Disord 2004;28:57-64.

72. Liddle RA, Green GM, Conrad CK, Williams JA. Proteins but not amino acids, carbohydrates, or fats stimulate cholecystokinin secretion in the rat. Am J Physiol 1986;251:G243-8.

73. Cummings NK, Soares MJ, James AP, Ping-Delfos WC. Comparison of dairy and non-dairy sources of calcium on thermogenesis and substrate oxidation in humans. Asia Pac J Clin Nutr 2004;13:S87.

74. Ping-Delfos WC, Soares MJ, Cummings NK. Acute suppression of spontaneous food intake following dairy calcium and vitamin D. Asia Pac J Clin Nutr 2004;13:S82.

75. Soares MJ, Ping-Delfos WC, James AP, Cummings NK. Dairy calcium and vitamin D stimulate postprandial thermogenesis: effect of sequential meals. Asia Pac J Clin Nutr 2004;13:S56.

76. Schrauwen P. Determinants of energy and substrate metabolism. Maastricht: University of Maastricht, 1998.

77. Ha E, Zemel MB. Functional properties of whey, whey components, and essential amino acids: mechanisms underlying health benefits for active people (review). J Nutr Biochem 2003;14:251-8.

78. Fouillet H, Mariotti F, Gaudichon C, Bos C, Tome D. Peripheral and splanchnic metabolism of dietary nitrogen are differently affected by the protein source in humans as assessed by compartmental modeling. J Nutr 2002;132:125-33.

79. Garlick PJ, Grant I. Amino acid infusion increases the sensitivity of muscle protein synthesis in vivo to insulin. Effect of branched-chain amino acids. Biochem J 1988;254:579-84. 


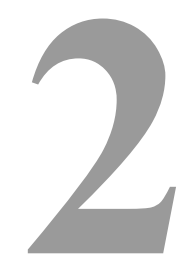

\section{The Relation between Calcium Intake and Body Composition in a Dutch Population: The Amsterdam Growth and Health Longitudinal Study}

N. Boon ${ }^{1}$, L. L. J. Koppes ${ }^{2,3}$, W. H. M. Saris ${ }^{1}$, and W. Van Mechelen ${ }^{2,3}$

${ }^{1}$ Nutrition and Toxicology Research Institute Maastricht (NUTRIM), University of Maastricht, Maastricht, The Netherlands.

${ }^{2}$ Institute for Research in Extramural Medicine, Vrije Universiteit University Medical Center, Amsterdam, The Netherlands.

${ }^{3}$ Department of Public and Occupational Health, Vrije Universiteit University Medical Center, Amsterdam, The Netherlands.

Am J Epidemiol 2005;1:27-32. 


\begin{abstract}
To investigate whether dietary calcium intake is related to body mass index and the sum of four skinfolds among subjects in the Amsterdam Growth and Health Longitudinal Study (the Netherlands), the authors followed a cohort of men and women from age 13 years in 1977 to age 36 years in 2000. Longitudinal linear regression analyses were performed with generalized estimating equations in continuous and categorical models, with adjustment for possible confounders. Results showed that calcium intake during adolescence is a weak predictor of calcium intake in adulthood. In this population, only a slight indication was found of a weak inverse relation of calcium intake with body composition. No differences were observed between the middle (800-1,200 mg/day) and high $(>1,200 \mathrm{mg} /$ day $)$ groups of calcium intake, suggesting a threshold of approximately $800 \mathrm{mg} /$ day above which calcium intake has no additional beneficial effect on body composition.
\end{abstract}

Keywords: body composition, calcium, dietary, obesity, skinfold thickness 


\section{Introduction}

The prevalence of obesity has increased markedly during the past two decades, making obesity an important risk factor for the development of type 2 diabetes, various types of cancer, and cardiovascular complications. The first indication of an inverse relation between calcium intake and body weight came from research by McCarron et al. in 1984 (1). Since then, this inverse relation between calcium intake and body composition or body weight has been observed in a large variety of populations (2-8). In a few other studies, however, no effects were found (9-11), while, in three studies, a genderspecific effect for an altered calcium intake was observed (12-14).

One possible mechanism for the relation between calcium intake and body weight has been suggested by various authors: in cell cultures of human adipocytes, increasing $1,25-\mathrm{OH}_{2} \mathrm{D}_{3}$ (calcitriol) levels can increase lipogenesis, decrease lipolysis, and increase messenger RNA expression of a number of fat-metabolism-related genes by stimulating calcium influx (15-20). The concentration of calcitriol increases when calcium intake is decreased (21). However, since most of the investigations studying the association of calcium intake and energy with substrate metabolism on the whole-body level were performed in humans or rodents during energy restriction $(6,11,22-24)$, it is not clear whether it is possible to translate the results of these investigations to humans under free-living conditions.

Another mechanism that could explain the relation between calcium intake and body weight is fat binding in the gut. Increasing dietary calcium intake increases the calcium concentration in the intestine, which in turn induces formation of insoluble fatty acid and bile acid soaps that are excreted through the faeces, thus decreasing the amount of dietary fat available for oxidation and/or storage. In randomized clinical trials, increasing dietary calcium intake by $905-4,000 \mathrm{mg}$ per day increased faecal fat excretion by up to $8.2 \mathrm{~g}$ per day $(25-27)$. However, a compensatory increase in energy intake in response to this decreased availability of dietary fat, to restore energy balance, cannot be excluded.

To our knowledge, all epidemiologic studies on the relation between calcium intake and body weight thus far are from cohorts whose median intake of calcium is relatively low. In the Netherlands, intake of this mineral is much higher; calcium intake levels are about $1,068 \mathrm{mg}$ per day in young men and $963 \mathrm{mg}$ per day in young women (28). It is possible that, to regulate body weight, calcium intake is optimal in the Dutch population.

Therefore, we wanted to test whether an inverse relation between dairy products/calcium intake and body weight was present in a population with a relatively high habitual intake of dairy products and calcium, such as the participants of the Amsterdam Growth and Health Longitudinal Study (AGAHLS) in the Netherlands. In addition, we investigated whether fiber and energy intake and physical activity confounded this relation. 


\section{Materials and methods}

\section{Subjects and study design}

In 1977, boys and girls whose mean age was 13 (standard deviation, 0.7) years and who attended a secondary school in the Netherlands-more than 95 percent were Caucasianwere assessed on regarding a wide range of characteristics including dietary calcium intake and body composition. Three measurements on the same subjects followed annually from 1978 through 1980. Additional follow-up measurements were performed in 1985, 1991, 1996, and 2000 when the subjects were an average age of 21, 27, 32, and 36 years, respectively. An equally large and same-aged cohort from another secondary school was assessed only once in the first 4 years of the study and was reassessed in 1996 and 2000 only. This difference between the two schools explains the increased number of participants for the follow-up measurements at ages 32 and 36 years (table 1). In total, 296 men and 333 women participated in the AGAHLS. The method used to measure dietary calcium intake and body composition remained the same over the 23 years of follow-up. The exact design and methods of the AGAHLS have been described in detail previously (29).

Table 1: Means and standard deviations of dietary calcium intake, body mass index and sum of skinfolds at the 8 follow-up measurements in men and women who were followed from age 13 to 36 years in the Amsterdam Growth and Health Longitudinal Study, 1977-2000.

\begin{tabular}{ccccccccc}
\hline Age & \multicolumn{3}{c}{$\mathrm{N}$} & \multicolumn{2}{c}{$\mathrm{Ca} 2+(\mathrm{mg} / \mathrm{day})$} & \multicolumn{2}{c}{ BMI $(\mathrm{kg} / \mathrm{m} 2)$} & \multicolumn{2}{c}{ S4S } \\
\hline & $\mathrm{M}$ & $\mathrm{W}$ & $\mathrm{M}$ & $\mathrm{W}$ & $\mathrm{M}$ & $\mathrm{W}$ & $\mathrm{M}$ & $\mathrm{W}$ \\
13 & 187 & 204 & $1122 \pm 408$ & $991 \pm 396$ & $17.6 \pm 1.7$ & $18.5 \pm 2.2$ & $2.8 \pm 1.2$ & $3.8 \pm 1.4$ \\
14 & 146 & 170 & $1140 \pm 1218$ & $988 \pm 412$ & $18.2 \pm 1.8$ & $19.2 \pm 2.3$ & $2.7 \pm 1.0$ & $4.3 \pm 4.7$ \\
15 & 150 & 170 & $1218 \pm 491$ & $921 \pm 382$ & $18.9 \pm 1.9$ & $19.6 \pm 2.2$ & $2.7 \pm 0.9$ & $4.7 \pm 1.6$ \\
16 & 132 & 173 & $1198 \pm 467$ & $929 \pm 388$ & $19.2 \pm 1.9$ & $20.1 \pm 2.3$ & $2.7 \pm 0.9$ & $4.9 \pm 1.6$ \\
21 & 93 & 107 & $1325 \pm 562$ & $1055 \pm 446$ & $21.4 \pm 2.0$ & $21.6 \pm 2.7$ & $3.6 \pm 1.4$ & $5.4 \pm 1.9$ \\
27 & 84 & 97 & $1363 \pm 549$ & $1159 \pm 418$ & $22.5 \pm 2.2$ & $21.9 \pm 2.5$ & $3.6 \pm 1.4$ & $4.6 \pm 1.6$ \\
32 & 203 & 230 & $1372 \pm 616$ & $1195 \pm 411$ & $24.0 \pm 2.6$ & $22.7 \pm 3.0$ & $4.2 \pm 1.7$ & $5.2 \pm 2.0$ \\
36 & 174 & 198 & $1435 \pm 606$ & $1264 \pm 418$ & $24.8 \pm 2.7$ & $23.4 \pm 3.3$ & $4.7 \pm 1.5$ & $5.5 \pm 1.9$ \\
\hline
\end{tabular}

Ca2+: calcium intake, BMI: Body Mass Index, S4S: Sum of Four Skinfolds, M: men, W: women, SD: standard deviation

\section{Calcium intake}

An extensive cross-check dietary history interview was used to assess dietary calcium intake (30). This interview provides information about subjects' habitual dietary intake by using the 4 weeks preceding the interview as a reference. A traditional, face-to-face interview was conducted during the first seven measurements, whereas, during the last measurement in 2000, a computer-assisted method was used. This interview consisted of two parts. The first was focused on drawing a pattern of the subjects' eating habits and meal patterns; in the second, an extensive checklist was used to give a more detailed description of all food and drink items consumed. "Cross-check" means that an additional check was performed on the reported frequency of meals eaten and on eating habits during the first part and the food and drink items mentioned in the second part of the interview. The computer-assisted method was added during the measurement to reduce interview time and inter-interviewer variability. This computer-assisted crosscheck dietary history interview has been validated against the traditional food history interview (31) and against the 3-day weighed food record and 24-hour dietary recall 
methods (32). From this interview, mean daily intake of various nutritional factors was calculated by using the Dutch Food and Nutrition Table (33).

\section{Body composition}

Anthropometric measurements of body height, body mass, and four skinfolds (biceps, triceps, and subscapular and cresta iliaca) were performed according to standard procedures (34). Body mass index (BMI), the quotient between body mass (in kilograms) and body height (in meters squared), was used as an indirect measure of fat mass. The sum of four skinfolds (S4S) was used as a more direct measure of fat mass (35).

\section{Analyses}

Longitudinal stability (tracking) of the variables of interest was analyzed using generalized estimating equations by regression of the initial value (age 13 years) to the values for all later measurements (ages 14, 15, 16, 21, 27, 32, and 36 years). This method results in one standardized regression coefficient, which can be interpreted as a longitudinal correlation coefficient (32). Generalized estimating equations take into account that repeated measurements on the same subject are not independent. Other advantages of analysis with generalized estimating equations are that time points do not have to be distributed evenly, and it copes with missing observations by using all available data (36). Generalized estimating equations was also used to study the genderspecific linear associations between dietary calcium intake and body composition (BMI and S4S). These longitudinal regression analyses were performed with continuous and categorical calcium data ( $<800$ vs. $800-1,200$ and $>1,200 \mathrm{mg} /$ day). The relation was estimated first by adjustment for age only and second with additional adjustment for total dietary energy intake, fiber intake, and level of habitual physical activity. Whether the magnitude of the associations was modified by age was studied by adding the interaction between age and calcium intake to the models. Generalized estimating equations were performed by using the Statistical Package for Interactive Data Analysis (37).

\section{Results}

Table 1 presents the number of participants per measurement and the means and standard deviations of dietary calcium intake, BMI, and S4S. The values for all central variables increased with age for both men and women. Over the 23 years of follow-up, average calcium intake was $1,269 \mathrm{mg}$ per day for men and 1,148 $\mathrm{mg}$ per day for women.

The results of the tracking analyses over the 23-year period indicate that dietary calcium intake had a relatively low stability, with coefficients of 0.38 for men and 0.41 for women. The stability of the body composition indicators BMI and S4S was higher: respectively, 0.84 and 0.70 for men and 0.82 and 0.87 for women. 
Table 2: Longitudinal linear regression coefficients and $95 \%$ confidence interval of dietary calcium intake (per $1000 \mathrm{mg} / \mathrm{day}$ ) on body mass index, and sum of skinfolds in men and women who were followed from age 13 to 36 years in the Amsterdam Growth and Health Longitudinal Study, 1977-2000.

\begin{tabular}{cccccccc}
\hline & \multicolumn{3}{c}{ Age adjusted } & \multicolumn{3}{c}{ Multiple adjusted* } \\
\hline \multirow{3}{*}{ BMI } & & $\mathrm{b} \dagger$ & \multicolumn{2}{c}{$95 \% \mathrm{CI} \dagger$} & $\mathrm{b}$ & \multicolumn{2}{c}{$95 \% \mathrm{CI}$} \\
& Men & $.07^{* *}$ & -.22 & .36 & $-.06^{* *}$ & -.35 & .23 \\
\multirow{3}{*}{$\mathrm{S} 4 \mathrm{~S}$} & Women & -.04 & -.37 & .29 & .20 & -.17 & .58 \\
& Men & $-.21^{*}, * * * *$ & -.35 & -.06 & $-.09 *$ & -.24 & .07 \\
& Women & -.17 & -.41 & .07 & .11 & -.17 & .40 \\
\hline
\end{tabular}

*Negative interaction with age, $\mathrm{p}<0.05 ; * *$ Negative interaction with age, $\mathrm{p}<0.01$; **** Significant regression coefficient, $\mathrm{p}<0.01$; * Regression coefficients adjusted for age, dietary energy intake, fibre intake, and habitual physical activity; $\dagger$ b: Longitudinal linear regression coefficients, CI: confidence interval, BMI: Body Mass Index, S4S: Sum of Four Skinfolds.

The linear regression results for the longitudinal relation between dietary calcium intake and BMI and S4S are reported in table 2 for the continuous estimate of calcium and in table 3 for three categories of calcium intake. Only two significant inverse associations were found. For men, in the age-adjusted model shown in table 2, a 1,000-mg per day higher dietary calcium intake was related to a $0.21-\mathrm{cm}$ lower S4S ( $\mathrm{p}=0.004)$. The negative interaction with age indicates that the magnitude of this inverse relation is larger (the relation is more negative) at older ages. For women, in the age-adjusted model shown in table 3 , the highest dietary calcium intake group ( $>1,200 \mathrm{mg} /$ day $)$ had a significantly lower S4S than those consuming less than $800 \mathrm{mg}$ of calcium per day ( $\mathrm{p}=$ 0.04). A comparable trend was observed for BMI, but it was not statistically significant $(\mathrm{p}=0.15)$. These two significant associations disappeared after adjustment for putative confounders.

24 Table 3: Longitudinal linear regression coefficients and 95\% confidence interval of dietary calcium intake (3 categories) on body mass index, and sum of skinfolds in men and women who were followed from age 13 to 36 years in the Amsterdam Growth and Health Longitudinal Study, 1977-2000.

\begin{tabular}{|c|c|c|c|c|c|c|c|c|}
\hline \multirow{3}{*}{$\mathrm{BMI} \dagger$} & \multirow{3}{*}{ Men } & \multirow{2}{*}{$\begin{array}{c}\begin{array}{c}\mathrm{Ca} 2+ \\
\text { category } \\
\text { (mg/day) }\end{array} \\
<800\end{array}$} & \multicolumn{3}{|c|}{ Age adjusted } & \multicolumn{3}{|c|}{ Multiple adjusted* } \\
\hline & & & $\mathrm{b}^{\dagger}$ & \multicolumn{2}{|c|}{$95 \% \mathrm{CI} \dagger$} & \multirow{3}{*}{$\begin{array}{c}\text { B } \\
\text { Ref }\end{array}$} & \multicolumn{2}{|c|}{$95 \% \mathrm{CI}$} \\
\hline & & $800-1200$ & -.14 & -.44 & .15 & & -.49 & .09 \\
\hline & & $>1200$ & $.03 * *$ & -.38 & .44 & & -.60 & .29 \\
\hline \multirow[t]{3}{*}{ BMI } & Women & $<800$ & Ref & & & Ref & & \\
\hline & & $800-1200$ & -1.8 & -.43 & .08 & & -.29 & .24 \\
\hline & & $>1200$ & -.26 & -.62 & .10 & & -.35 & .40 \\
\hline \multirow[t]{6}{*}{$\mathrm{S} 4 \mathrm{~S} \dagger$} & Men & $<800$ & Ref & & & Ref & & \\
\hline & & $800-1200$ & -.08 & -.25 & .10 & & -.20 & .17 \\
\hline & & $>1200$ & $-.09 * *$ & -.29 & .12 & & -.13 & .31 \\
\hline & Women & $<800$ & Ref & & & Ref & & \\
\hline & & $800-1200$ & -.15 & -.34 & .05 & & -.19 & .19 \\
\hline & & $>1200$ & $-.28 * * *$ & -.56 & -.01 & & -.26 & .34 \\
\hline
\end{tabular}

$*$ Negative interaction with age, $\mathrm{p}<0.05 ; * *$ Negative interaction with age, $\mathrm{p}<0.01 ; * * *$ Significant regression coefficient, $\mathrm{p}<0.05$; * Regression coefficients adjusted for age, dietary energy intake, fibre intake, and habitual physical activity.; $\dagger$ b: Longitudinal linear regression coefficients, CI: confidence interval, BMI: Body Mass Index, S4S: Sum of Four Skinfolds. 


\section{Discussion}

In the present investigation, we used data on calcium intake and body composition from the AGAHLS cohort to investigate whether the inverse relation between calcium intake and body weight observed for children and adults in the United States existed in the Netherlands as well as in a cohort of healthy young men and women whose calcium intake was relatively high. For both men and women, only one significant inverse relation was observed between calcium intake and S4S, whereas nonsignificant trends were found for BMI. Although these associations were statistically significant, they were smaller than those found in the observational studies performed in the United States. For men but not women, negative interactions with age were observed in continuous and categorical models. This finding indicates that calcium intake and body composition are more strongly inversely related in the higher age groups. Men in the higher age groups also had a considerably higher BMI and S4S, so it could be possible that the effect of a higher calcium intake is stronger in subjects with a larger fat mass. There have been previous reports of different effects of calcium intake on body composition in men and women, but they were not consistent. In the study by Jacqmain et al. (12), after adjustment for protein intake, no relation was observed for men, but a negative relation was observed for women. Kamycheva et al. (14) saw no effect in men and a positive relation for women. Loos et al. (13) saw no effect in Black women but a negative relation in Black men an White men and in White women. Thus, from these data, no consistent pattern emerges about a possible gender-specific effect of calcium intake on body composition.

No differences in BMI or S4S were observed between the middle and highest groups of calcium intake, which could mean that if calcium intake is more than $800 \mathrm{mg}$ per day, no additive beneficial effect of increasing the dietary calcium intake is present. Average calcium intake in the present study population was slightly higher than the average for the representative age groups in the Netherlands (28), and it was at leas 200-mg per day higher than in studies from the United States. This finding indicates that, in a population such as the AGAHLS cohort, whose calcium intake in general meets the recommended daily intake of 1,000-1,200 mg per day in the Netherlands, no effects on body weight and body composition are to be expected. In other words, a suboptimal calcium intake may increase the risk of developing obesity, but, above a certain threshold, an increased calcium intake does not give any further protection.

A limitation of the present investigation is that we were not able to correct for the possible confounding effects of a higher protein intake because of the high covariance between protein and calcium intake in this cohort. Compared with fats or carbohydrates, protein is known to have a higher satiety per kilojoule and to produce a higher dietinduced thermogenesis per kilojoule. Therefore, this macronutrient has been used in studies on body-weight regulation (38-42). In an intervention study in which subjects received an ad libitum diet with a reduced fat concentration, Skov et al. (41) observed that subjects receiving a high-protein diet lost significantly more body weight than the group receiving a diet with lower protein content. In obese subjects who had lost weight because of a 4-week very low energy diet, Westerterp-Plantenga et al. (43) saw that adding a protein supplement to an isocaloric diet resulted in less body weight regain than in those in a control group who did not receive the protein supplement. These trials show that an increase in protein intake may affect body weight in subjects consuming an ad libitum or isocaloric diet, at least during and after weight loss. 
Underreporting of food intake by obese subjects is well established $(44,45)$. This problem may have caused a type I error in the present investigation because it could have led to underestimation of calcium intake among subjects with a higher BMI and S4S. The absence of significant inverse findings in the model adjusted for total energy intake supports this hypothesis. This underreporting is expected to be related more to fat than to calcium or protein intake, however $(44,45)$. On the other hand, the recall method used here to measure food intake is less accurate than those methods used in some intervention studies that report an inverse relation between calcium intake and body weight. Indirectly measuring food intake in the present study could have resulted in a relatively large amount of error in the calcium data and consequently may have caused type II errors. In other words, the relative absence of significant inverse findings in the present study may also be explained by the fact that we used a dietary history interview, whereas most epidemiologic investigations mentioned in this paper used food diaries to measure food intake.

In line with others (46), our tracking analyses show that dietary calcium intake has a low stability over time. This finding indicates that calcium intake during adolescence is a weak predictor of calcium intake later in life. From this finding it is hypothesized that the effects of a single dietary calcium intake intervention will not last a long time. In contrast, BMI and S4S show much higher tracking coefficients; therefore, assessments of BMI and S4S during adolescence will be quite good predictors of the relative levels of BMI and S4S at adulthood. This high stability of BMI and S4S shows the opportunity for early selection of subjects who have a high risk of becoming obese.

In conclusion, the results of this investigation of relatively healthy subjects followed from age 13 to 36 years indicate a weak inverse relation of calcium intake with body composition. This finding may seem to be in contrast with that of previous investigations, where stronger inverse relations were found, but it may be explained by the fact that average calcium intake is much higher in the present population than in those assessed in previous studies. There may be a threshold for calcium intake above, which no additive beneficial effect exists. In the present investigation, this calcium intake threshold was about $800 \mathrm{mg}$ per day. 


\section{References}

1. McCarron DA. Dietary calcium as an antihypertensive agent. Nutr Rev 1984;42:223-5.

2. Buchowski MS, Semenya J, Johnson AO. Dietary calcium intake in lactose maldigesting intolerant and tolerant African-American women. J Am Coll Nutr 2002;21:47-54.

3. Davies KM, Heaney RP, Recker RR, et al. Calcium intake and body weight. J Clin Endocrinol Metab 2000;85:4635-8.

4. Heaney RP. Normalizing calcium intake: projected population effects for body weight. J Nutr 2003;133:268S-270S.

5. Carruth BR, Skinner JD. The role of dietary calcium and other nutrients in moderating body fat in preschool children. Int J Obes Relat Metab Disord 2001;25:559-66.

6. Lin YC, Lyle RM, McCabe LD, McCabe GP, Weaver CM, Teegarden D. Dairy calcium is related to changes in body composition during a two-year exercise intervention in young women. $\mathrm{J}$ Am Coll Nutr 2000;19:754-60.

7. Novotny R. Dairy, calcium and body composition of multiethnic youth. Asia Pac J Clin Nutr 2004;13:S36 (abstr.).

8. Skinner JD, Bounds W, Carruth BR, Ziegler P. Longitudinal calcium intake is negatively related to children's body fat indexes. J Am Diet Assoc 2003;103:1626-31.

9. Atkin LM, Davies PS. Diet composition and body composition in preschool children. Am J Clin Nutr 2000;72:15-21.

10. Phillips SM, Bandini LG, Cyr H, Colclough-Douglas S, Naumova E, Must A. Dairy food consumption and body weight and fatness studied longitudinally over the adolescent period. Int J Obes Relat Metab Disord 2003;27:1106-13.

11. Shapses SA, Heshka S, Heymsfield SB. Effect of calcium supplementation on weight and fat loss in women. J Clin Endocrinol Metab 2004;89:632-7.

12. Jacqmain M, Doucet E, Despres JP, Bouchard C, Tremblay A. Calcium intake, body composition, and lipoprotein-lipid concentrations in adults. Am J Clin Nutr 2003;77:1448-52.

13. Loos RJ, Rankinen T, Leon AS, et al. Calcium Intake Is Associated with Adiposity in Black and White Men and White Women of the HERITAGE Family Study. J Nutr 2004;134:1772-1778.

14. Kamycheva E, Joakimsen RM, Jorde R. Intakes of calcium and vitamin d predict body mass index in the population of Northern Norway. J Nutr 2003;133:102-6.

15. Xue B, Greenberg AG, Kraemer FB, Zemel MB. Mechanism of intracellular calcium $([\mathrm{Ca} 2+] \mathrm{i})$ inhibition of lipolysis in human adipocytes. Faseb J 2001;15:2527-9.

16. Shi H, Halvorsen YD, Ellis PN, Wilkison WO, Zemel MB. Role of intracellular calcium in human adipocyte differentiation. Physiol Genomics 2000;3:75-82.

17. Shi H, Norman AW, Okamura WH, Sen A, Zemel MB. 1alpha,25-dihydroxyvitamin D3 inhibits uncoupling protein 2 expression in human adipocytes. Faseb J 2002;16:1808-10.

18. Zemel MB. Nutritional and endocrine modulation of intracellular calcium: implications in obesity, insulin resistance and hypertension. Mol Cell Biochem 1998;188:129-36.

19. Shi H, Dirienzo D, Zemel MB. Effects of dietary calcium on adipocyte lipid metabolism and body weight regulation in energy-restricted aP2-agouti transgenic mice. Faseb J 2001;15:291-3.

20. Shi H, Norman AW, Okamura WH, Sen A, Zemel MB. 1alpha,25-Dihydroxyvitamin D3 modulates human adipocyte metabolism via nongenomic action. Faseb J 2001;15:2751-3.

21. DeLuca HF, Zierold C. Mechanisms and functions of vitamin D. Nutr Rev 1998;56:S4-10; discussion S 54-75.

22. Zemel MB. Dietary calcium and dairy products accelerate weight and fat loss during energy restriction in obese adults. Nutr W Abstracts 2001:342-3s.

23. Zemel MB. Effects of calcium-fortified breakfast cereal on adiposity in a transgenic mouse model of obesity. Faseb J 2001:598 (abstr.).

24. Zemel MB, Thompson W, Milstead A, Morris K, Campbell P. Calcium and Dairy Acceleration of Weight and Fat Loss during Energy Restriction in Obese Adults. Obes Res 2004;12:582-90.

25. Govers MJ, Termont DS, Lapre JA, Kleibeuker JH, Vonk RJ, Van der Meer R. Calcium in milk products precipitates intestinal fatty acids and secondary bile acids and thus inhibits colonic cytotoxicity in humans. Cancer Res 1996;56:3270-5.

26. Welberg JW, Monkelbaan JF, de Vries EG, et al. Effects of supplemental dietary calcium on quantitative and qualitative faecal fat excretion in man. Ann Nutr Metab 1994;38:185-91. 
27. Jacobsen R, Lorenzen JK, Toubro S, Krog-Mikkelsen I, Astrup A. Effect of short-term high dietary calcium intake on 24-h energy expenditure, fat oxidation, and faecal fat excretion. Int J Obes Relat Metab Disord 2005;29:292-301.

28. Zo eet Nederland 1998. Resultaten van de Voedselconsumptiepeiling 1998. Den Haag: Van Marken Delft Drukkers, 1998.

29. Kemper HCGe. Amsterdam Growth and Health Longitudinal Study, a 23-year follow-up from teenager to adult about lifestyle and health. Basel: Karger, 2004.

30. Post GB. Nutrition in Adolescence: A Longitudinal Study in Dietary Patterns from Teenager to Adult. Haarlem: De Vrieseborch, 1989.

31. Bakker I, Twisk JW, van Mechelen W, Mensink GB, Kemper HC. Computerization of a dietary history interview in a running cohort; evaluation within the Amsterdam Growth and Health Longitudinal Study. Eur J Clin Nutr 2003;57:394-404.

32. Mensink GB, Haftenberger M, Thamm M. Validity of DISHES 98, a computerised dietary history interview: energy and macronutrient intake. Eur J Clin Nutr 2001;55:409-17.

33. NEVO Table. Voorlichtingsbureau voor de voeding (Netherlands Nutrition Centre). Den Haag: Stichting Nederlands Voedingsstoffenbestand (Netherlands Food Composition Chart), 1996.

34. Weiner JS, Lourie JA. Human Biology, a guide to field methods. IBP Handbook. Oxford: Blackwell, 1969:8-29.

35. Durnin JV, Rahaman MM. The assessment of the amount of fat in the human body from measurements of skinfold thickness. Br J Nutr 1967;21:681-9.

36. Twisk JWR. Applied Longitudinal Data Analysis for Epidemiology; a practical guide. Cambridge: Cambridge University Press, 2003.

37. Gebski V, Leung O, McNeil D, Lunn D. SPIDA User Manual, Version 6. NSW, Australia: Macquarie University, 1992.

38. Farnsworth E, Luscombe ND, Noakes M, Wittert G, Argyiou E, Clifton PM. Effect of a high-protein, energy-restricted diet on body composition, glycemic control, and lipid concentrations in overweight and obese hyperinsulinemic men and women. Am J Clin Nutr 2003;78:31-9.

39. Eisenstein J, Roberts SB, Dallal G, Saltzman E. High-protein weight-loss diets: are they safe and do they work? A review of the experimental and epidemiologic data. Nutr Rev 2002;60:189-200.

40. Baba NH, Sawaya S, Torbay N, Habbal Z, Azar S, Hashim SA. High protein vs high carbohydrate hypoenergetic diet for the treatment of obese hyperinsulinemic subjects. Int J Obes Relat Metab Disord 1999;23:1202-6.

41. Skov AR, Toubro S, Ronn B, Holm L, Astrup A. Randomized trial on protein vs carbohydrate in ad libitum fat reduced diet for the treatment of obesity. Int J Obes Relat Metab Disord 1999;23:528-36.

42. Whitehead JM, McNeill G, Smith JS. The effect of protein intake on 24-h energy expenditure during energy restriction. Int J Obes Relat Metab Disord 1996;20:727-32.

43. Westerterp-Plantenga MS, Lejeune MP, Nijs I, van Ooijen M, Kovacs EM. High protein intake sustains weight maintenance after body weight loss in humans. Int J Obes Relat Metab Disord 2004;28:57-64.

44. Goris AH, Westerterp-Plantenga MS, Westerterp KR. Undereating and underrecording of habitual food intake in obese men: selective underreporting of fat intake. Am J Clin Nutr 2000;71:130-4.

45. Novotny JA, Rumpler WV, Riddick H, et al. Personality characteristics as predictors of underreporting of energy intake on 24-hour dietary recall interviews. J Am Diet Assoc 2003;103:1146-51.

46. Nicklas TA. Calcium intake trends and health consequences from childhood through adulthood. J Am Coll Nutr 2003;22:340-56. 


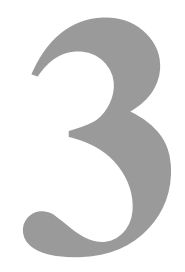

\section{Dietary macronutrient distribution in relation to energy intake and body fatness}

Lando LJ Koppes ${ }^{1,2}$, Niels Boon ${ }^{3}$, Astrid CJ Nooyens ${ }^{2,4}$, Willem van Mechelen ${ }^{1,2}$, Wim HM Saris $^{3}$

${ }^{1}$ EMGO Institute, VU University Medical Center, Amsterdam, The Netherlands

${ }^{2}$ Department of Public and Occupational Health, VU University Medical Center, Amsterdam, The Netherlands

${ }^{3}$ Nutrition and Toxicology Research Institute Maastricht (NUTRIM), University of Maastricht, Maastricht, The Netherlands

${ }^{4}$ Institute of Health Sciences, Faculty of Earth and Life Sciences, Vrije Universiteit Amsterdam, The Netherlands.

Am J Clin Nutr 2006.(submitted) 


\begin{abstract}
Background: There are indications that the relative amounts of intake of the four macronutrients protein, carbohydrate, fat and alcohol have an effect on energy intake and on body fatness. This, however, has not been investigated in detail.

Methods: Eight follow-up measurements have been performed over a period of 23 years in 168 men and 182 women who participate in the Amsterdam Growth and Health Longitudinal Study (AGAHLS). From the first measurement at the age of 13 years onwards, dietary intake, physical activity and the thickness of four skinfolds have been assessed. In addition, at the last follow-up at the age of 36 years, body fatness was assessed using DXA. The energy percentages (En\%) from protein, carbohydrates, fats and alcohol were related to total dietary energy intake, the amount of physical activity, and to the sum of the thickness of the skinfolds in longitudinal Generalised Estimating Equations (GEE) regression analyses. In addition, the 23-year development of the four En\%'s were compared for the men and women who did and did not have high body fatness at the age of 36 years.

Results: The GEE analyses showed that in both men and in women a lower En\% from protein, and a higher En\% from fat were related with a higher total energy intake. Furthermore, in men, a lower relative intake of carbohydrates was related with a higher total energy intake. No significant relationships of the En\%'s with physical activity or the skinfold thickness were observed except for an inverse relationship between alcohol consumption and physical activity in women. The men and women with high body fatness at the age of 36 years had a one En\% higher protein intake at the age of 32 and 36 years. In addition, the women with high body fatness at the age of 36 years had a two percent lower En\% from alcohol at the age of 32 and 36 years. Before the age of 32 years, no clear differences between the men and women with and without high body fatness at adult age were found.

Conclusion: High intake of protein and a low intake of fat and, in men, high intake of carbohydrate are inversely related to total energy intake. In apparent contrast to this, subjects with high body fatness at the age of 36 years had a higher relative protein intake at the age of 32 and 36 years. In women, high body fatness at the age of 36 years is related to a lower alcohol intake at the age of 32 and 36 years.
\end{abstract}

Keywords: macronutrient intake, energy intake, body composition, AGAHLS 


\section{Introduction}

Obesity, the excess of body fatness, is an increasingly important worldwide public health problem (1). A misbalance between energy intake and energy expenditure causes obesity. The relative amounts consumed of the four macronutrients may also matter, because high protein diets have been found to be inversely related to obesity (2-6). Protein is known to cause a higher diet induced thermogenesis per kilojoule than fats or carbohydrates, leading to a lower metabolic efficiency (7-9). The synthesis of peptide bonds, the production of urea and gluconeogenesis are all metabolic processes with a high energy requirement that are elevated by the consumption of a high protein diet ( 7 , 10). High protein diets have also been reported to increase satiety (11-13). This satiety effect may be mediated by cholecystokynine (CCK), as in rodents, a high protein diet induces increased CCK production (14), and CCK has been linked to an increased satiety in humans (15).

Protein has been used in experimental studies on body weight regulation (2-6). These trials show that an increase in protein intake may reduce body weight in subjects consuming an ad libitum or isocaloric diet, at least during and after weight loss. These trials, however, concern relatively short-term interventions whereas the more long lasting changes in body weight are those that develop slowly over longer periods of time. In addition, these trials are not performed in general populations, whereas the general population is where the obesity pandemic is developing at the moment.

The other three macronutrients (fat, carbohydrate and alcohol) also may play a role in body weight regulation. Several studies have shown that a relative reduction of either the carbohydrate $(16-18)$ or the fat intake $(19,20)$ in parallel with an increased protein intake could have weight-lowering effects. Furthermore, the energy intake from alcohol has been shown to have J-shaped relationships with body weight indices $(21,22)$. So, changes in the relative consumption amounts of protein, carbohydrates, fats and alcohol may have an effect on body weight and the amount of body fat.

In this study we will investigate if the relative amounts of intake of the various macronutrients are related to body fatness in a cohort of adolescents who were followed with repeated measurements over a period of 23 years until the age of 36 years. In addition, we will compare the development over those 23 years of the relative consumption amounts of the four macronutrients for men and women with and for those without high body fatness at adult age.

\section{Methods}

\section{Subjects and design}

In 1977, the Amsterdam Growth and Health Longitudinal Study (AGAHLS) started with assessments on a wide range of characteristics in boys and girls aged 13 years (SD 0.7). They were all first and second year pupils from two equally large secondary schools in The Netherlands. In the pupils from the one school, follow-up measurements were performed in 1978, 1979, 1980 1985, 1991, 1996, and 2000 when the participants had an average age of $14,15,16,21,27,32$, and 36 years, respectively. The pupils from the other school were assessed only once in the first four years of the study, and were 
reassessed in 1996 and 2000 only. In total, 698 13-year-old pupils were included in the AGAHLS of whom 350 have complete data of the follow-up measurements that were performed 23-years later at the age of 36 years. The exact design and methods of the AGAHLS have been described in detail previously (23).

\section{Dietary intake}

An extensive cross-check dietary history interview was administered at each follow-up (24). This interview provides information about the habitual dietary intake of the participants using the 4 weeks preceding the interview as a reference. The interview consisted of two parts. The first part focused on drawing a pattern of the participants' eating habits and meal patterns and in the second part an extensive checklist was used to give a more detailed description of all of the food and drink items consumed. The 'cross-check' indicates that additional checks were performed on the items mentioned in the second part of the interview. This was a traditional face-to-face interview during the first seven measurements, whereas during the last measurement at the mean age of 36 years, a computer-assisted method was used. The addition of the computer-assistance was done in order to decrease the interview time and to decrease the betweeninterviewer variability. This computer-assisted cross-check dietary history interview has been validated against the traditional food history interview and against the 3-day weighed food record and $24 \mathrm{~h}$ dietary recall methods $(25)$. The mean daily intake of various nutritional factors was calculated using the Dutch Food and Nutrition Table (26).

\section{Body fatness}

At each year of measurement, the thickness of four skinfolds (biceps, triceps, subscapular and cresta iliaca) was assessed according to standard procedures (27). At the last measurement, at the age of 36 years, whole-body DXA (Hologic QDR-2000, software version V5.67A, Hologic Inc., Waltham, MA) was used to assess body fat percentage. Participants were classified as having high body fatness if their percentage body fat at this age- 36 measurement exceeded $25 \%$ for men or $35 \%$ for women.

\section{Analyses}

Gender and follow-up specific standardized values were calculated for total energy intake, physical activity, and the sum of four skin folds. This standardization enabled the use of data from all eight follow-ups in one longitudinal analysis by excluding bias due to follow-up associated correlations between the mean values of the sample. Generalized Estimating Equation (GEE) analyses with an exchangeable correlation structure were used to study the age adjusted relationships of the energy percentages (En\%) from protein, fat, carbohydrates and alcohol with total energy intake, the physical activity level, and with the sum of four skin folds. The physical activity level is presumed a putative confounder of the relationship between the relative energy contributions and the sum of skin folds if the relationships between the relative energy intakes by the nutrients were found significantly associated with the physical activity level. In that case, the relationship between the relative energy intakes and the sum of skin folds was performed with additional adjustment for the physical activity level. Total energy intake is a presumed mediator of the hypothesized causal path between the relative energy contributions of the macronutrients and the sum of skinfolds, and should therefore not be adjusted for. GEE analyses are longitudinal regression analyses that 
take into account that repeated measurements on the same individual are not independent. Other advantages of analyzing with GEE are that time points do not have to be distributed evenly and that it copes with missing observations by using all available data gathered over the 23-year period of follow-up (28).

The development of the En\% from fat, protein, carbohydrates and alcohol from mean age 13 to 36 years for the groups of men and women with high and low body fatness at the age of 36 years was analysed with GEE also. Time was treated as a categorical variable to estimate these developments, which are presented in graphics. All analyses were performed with SAS software, version 8.2.

\section{Results}

Table 1 shows that the longitudinal development of the relative amount of protein intake was inversely related to the longitudinal development of total energy intake. A one percent higher energy intake in the form of protein was related to a 0.128 SD's lower total energy intake in men, and to a 0.156 SD's lower energy intake in women. The 23year development of the relative amount of fat intake was positively related to total energy intake, in a way that a one percent higher relative energy contribution in the form of fat was related to a 0.039 and 0.043 SD's higher energy intake in men and women, respectively. The En\% from carbohydrates was inversely related to total energy intake in men only, and the En\% from alcohol was not related to total energy intake.

With regard to the longitudinal development of physical activity, a significant relationship was found only in women for the relative energy intake in the form of alcohol. A one percent higher relative contribution in the form of alcohol was related to a 0.034 SD's lower physical activity level. With regard to the sum of four skinfolds, the development of the relative contributions to total energy intake of none of the four macronutrients showed a significant relationship (all p-values $>0.25$ ).

Table 1: Age adjusted longitudinal regression coefficients using all available data gathered between age 13 and 36 years of the relative contributions to total energy intake of the four macronutrients (protein, fat, carbohydrate and alcohol) with total energy intake, physical activity and the sum of skinfolds

\begin{tabular}{lcccccc}
\hline & \multicolumn{2}{c}{ Total energy intake } & \multicolumn{2}{c}{ Physical activity } & \multicolumn{2}{c}{ Sum of skinfolds } \\
\hline & Men & Women & Men & Women & Men & Women \\
PRO $^{1}$ & $-0.128^{\wedge}$ & $-0.156^{\wedge}$ & -0.018 & -0.010 & 0.015 & 0.014 \\
FAT $^{1}$ & $0.039^{\wedge}$ & $0.043^{\wedge}$ & -0.004 & 0.000 & 0.005 & 0.002 \\
CHO $^{1}$ & $-0.017^{\#}$ & 0.000 & 0.003 & 0.009 & 0.004 & 0.002 \\
ALC $^{1}$ & 0.017 & 0.021 & 0.012 & -0.034 & -0.011 & 0.009 \\
\hline
\end{tabular}

${ }^{1}$ PRO: EN\% from protein, FAT: EN\% from fat, CHO: EN\% from carbohydrates, ALC: EN\% from alcohol; * year-of-measurement-specific Z-scores were used; \#: $\mathrm{p}<0.05 ; \wedge$ : $\mathrm{p}<0.0001$.

At the age of 36 years, 49 of the 168 men had a body fat percentage $\geq 25$, and 59 of the 182 women had a body fat percentage $\geq 35$. Figure 1 shows the development from age 13 to 36 of the relative contributions of the four macronutrients for the men and women with and without high body fatness at the age of 36 years. Men with high body fatness at the age of 36 years had a higher relative protein intake at the ages 32 and 36 years as compared with the men without high body fatness $(p<0.05$ at the age of 32 and $p<0.01$ at the age of 36) (figure 1A). The relative protein intake in women with high body fatness at the age of 36 years was around one percent higher throughout the whole 23year period of follow-up than in those without high body fatness (figure 1E). This 
difference was statistically significant at the measurements at the age of 32 and 36 $(p<0.05)$. The relative energy intake from fat and carbohydrates from age 13 to 36 were not related with body fatness at the age of 36 years (figures $1 \mathrm{~B}, 1 \mathrm{C}, 1 \mathrm{~F}$ and $1 \mathrm{G}$ ). The relative contribution to total energy intake in the form of alcohol was one to two percent smaller from age 27 years onwards in women with high body fatness at the age of 36 years (figure $1 \mathrm{H})$.

\section{Discussion}

In this investigation, we have studied the longitudinal associations between the relative intakes of the four macronutrients (protein, fat, carbohydrate and alcohol) with body composition. For men, we observed that the intake of protein and carbohydrates were inversely associated with total energy intake, and that intake of fat was positively associated with total energy intake. In women, the intake of protein was inversely related, and the intake of fat was positively related to total energy intake. These findings can be explained by the lower energy density of carbohydrate and protein as compared with fat because it has been observed that the energy density of the diet is positively related to total energy intake (29).

Given the inverse associations between protein intake and overall energy intake, inverse associations were expected also between protein intake and skin fold thickness. Here, however, small and non-significant positive trends were found. This unexpected finding is even stronger for our data on high body fatness, where in both men and women the energy intake from protein was positively related to total fat mass at the age of 36 years. The higher precision and validity in estimating body fatness using DXA measurements as compared with using skin fold thickness measurements may explain this difference in statistical significance found between the two methods (30).

One explanation for the apparent inconsistency that subjects with a relatively high protein intake have a lower total energy intake and at the same time a higher body fatness could be that these subjects are also the ones with the lower levels of physical activity. Indeed, inverse associations between $\mathrm{En} \%$ from protein and physical activity were found. These associations, however, were small and not significant and therefore can only to a minor degree explain the unexpected finding.

Our finding that a higher protein intake is associated with a high body fat percentage is not in line with previous investigations, as these show beneficial effects of high protein and low fat and carbohydrate diets during weight loss and weight maintenance $(2-6,13)$. These studies, however, were short-term intervention trials in overweight populations with weight loss as a primary endpoint, whereas we investigated the associations of the four macronutrients over a longer period of energy balance in a general population. The difference between our finding and that of the trials therefore may be due to the weight status of the subjects, or to the fading out (or even more than that) of dietary intervention effects.

Women with a high body fat percentage at the age of 36 years were found to have a lower intake of alcohol at the age of 32 and 36 years than women with a lower percentage of body fat. This finding may be explained by alcohol abstention or moderation as a means of weight reduction by the women with high body fatness, or by underreport of alcohol consumption by these women for example due to social desirable answering. The inverse association found between alcohol consumption and the 
physical activity level makes it unlikely that a difference in physical activity levels can explain why women with a high body fat percentage drink less alcohol.

In summary, in men a higher relative intake of carbohydrate is associated with a lower total energy intake. In men and women, a higher relative protein intake and a lower relative intake of fat are associated with a lower total energy intake. These findings support the view that the energy density of the diet is associated with energy intake. No associations were found between the intake of any of the macronutrients and skin fold thickness. In apparent contrast to the relationships we observed between protein intake and overall energy intake, male and female subjects with a high body fat percentage at the age of 36 years had a higher intake of protein at the age of 32 and 36 years. These results are in contrast with previous investigations showing beneficial effects on body weight of a relatively high protein intake and a relatively low intake of fat and carbohydrate during and after weight loss. The difference in study findings may be related to the weight status of the subjects, and to the fact that we looked at the more long-term associations of differences in macronutrient intake in subjects during an energy balance situation. 


\section{Chapter 3}

Figure 1: Development (with 95\% CIs) from mean age 13 to 36 years of energy intake in the form of protein, fat, carbohydrates, and alcohol as percentages of total energy intake in men $(\mathrm{N}=168$; graphs A-D) and women $(\mathrm{N}=182$; graphs $\mathrm{E}-\mathrm{H})$ stratified for high and low percentage body fat (PBF) at the mean age of 36 years. $*$ : $<<0.05 ; \uparrow: \mathrm{p}<0.01 ;$; $\mathrm{p}<0.001$.
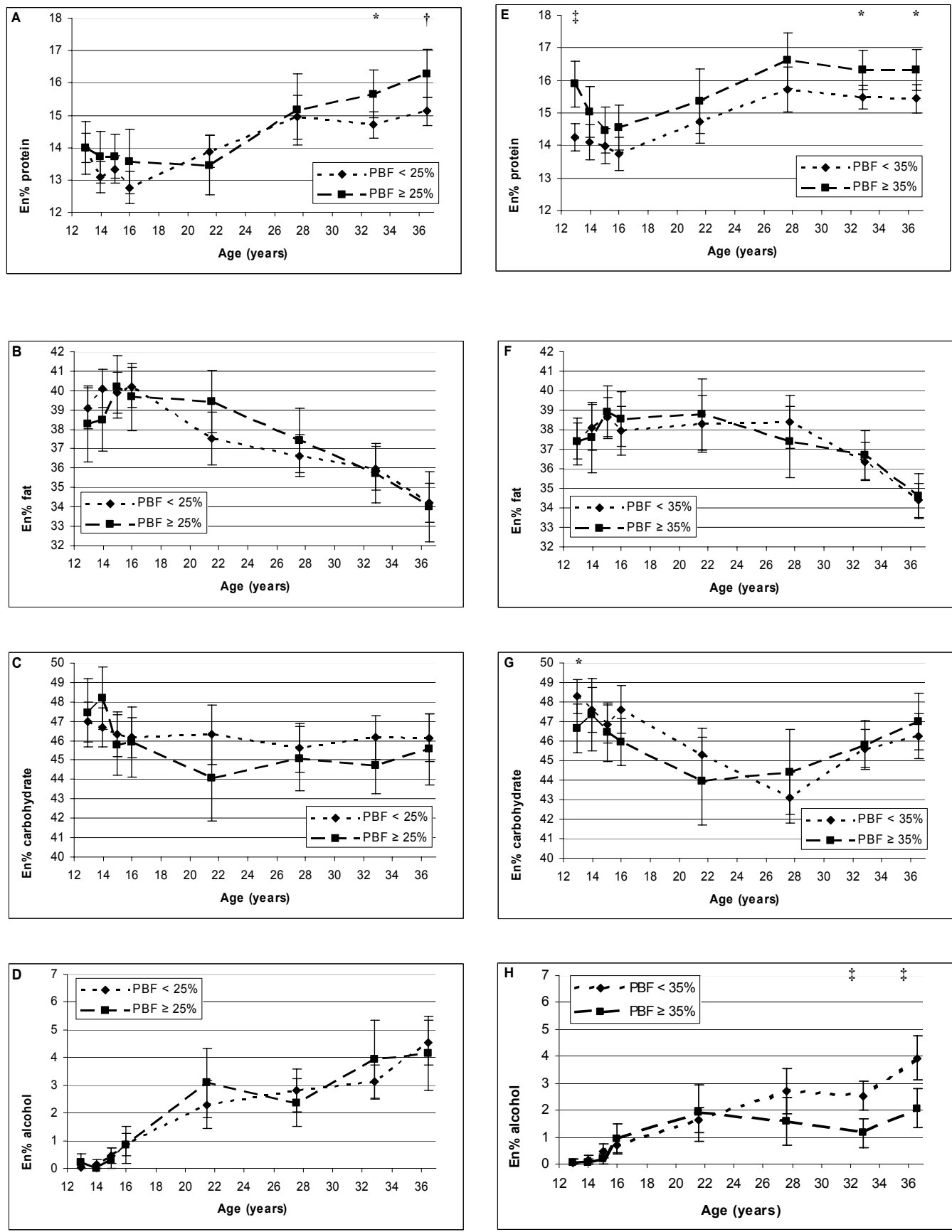


\section{References}

1. WHO. Diet, nutrition and the prevention of chronic diseases. 2003.

2. Farnsworth E, Luscombe ND, Noakes M, Wittert G, Argyiou E, Clifton PM. Effect of a high-protein, energy-restricted diet on body composition, glycemic control, and lipid concentrations in overweight and obese hyperinsulinemic men and women. Am J Clin Nutr 2003;78:31-9.

3. Eisenstein J, Roberts SB, Dallal G, Saltzman E. High-protein weight-loss diets: are they safe and do they work? A review of the experimental and epidemiologic data. Nutr Rev 2002;60:189-200.

4. Baba NH, Sawaya S, Torbay N, Habbal Z, Azar S, Hashim SA. High protein vs high carbohydrate hypoenergetic diet for the treatment of obese hyperinsulinemic subjects. Int J Obes Relat Metab Disord 1999;23:1202-6.

5. Skov AR, Toubro S, Ronn B, Holm L, Astrup A. Randomized trial on protein vs carbohydrate in ad libitum fat reduced diet for the treatment of obesity. Int J Obes Relat Metab Disord 1999;23:528-36.

6. Whitehead JM, McNeill G, Smith JS. The effect of protein intake on 24-h energy expenditure during energy restriction. Int J Obes Relat Metab Disord 1996;20:727-32.

7. Johnston CS, Day CS, Swan PD. Postprandial thermogenesis is increased $100 \%$ on a high-protein, lowfat diet versus a high-carbohydrate, low-fat diet in healthy, young women. J Am Coll Nutr 2002;21:5561.

8. Mikkelsen PB, Toubro S, Astrup A. Effect of fat-reduced diets on 24-h energy expenditure: comparisons between animal protein, vegetable protein, and carbohydrate. Am J Clin Nutr 2000;72:1135-41.

9. Westerterp KR, Wilson SA, Rolland V. Diet induced thermogenesis measured over $24 \mathrm{~h}$ in a respiration chamber: effect of diet composition. Int J Obes Relat Metab Disord 1999;23:287-92.

10. Robinson SM, Jaccard C, Persaud C, Jackson AA, Jequier E, Schutz Y. Protein turnover and thermogenesis in response to high-protein and high-carbohydrate feeding in men. Am $\mathrm{J}$ Clin Nutr 1990;52:72-80.

11. Poppitt SD, McCormack D, Buffenstein R. Short-term effects of macronutrient preloads on appetite and energy intake in lean women. Physiol Behav 1998;64:279-85.

12. Stubbs RJ, van Wyk MC, Johnstone AM, Harbron CG. Breakfasts high in protein, fat or carbohydrate: effect on within-day appetite and energy balance. Eur J Clin Nutr 1996;50:409-17.

13. Westerterp-Plantenga MS, Lejeune MP, Nijs I, van Ooijen M, Kovacs EM. High protein intake sustains weight maintenance after body weight loss in humans. Int J Obes Relat Metab Disord 2004;28:57-64.

14. Liddle RA, Green GM, Conrad CK, Williams JA. Proteins but not amino acids, carbohydrates, or fats stimulate cholecystokinin secretion in the rat. Am J Physiol 1986;251:G243-8.

15. Bowen J, Noakes M, Trenerry C, Clifton PM. Energy intake, ghrelin and CCK after different carbohydrate and protein preloads in overweight men. J Clin Endocrinol Metab 2006.

16. Foster GD, Wyatt HR, Hill JO, et al. A randomized trial of a low-carbohydrate diet for obesity. N Engl J Med 2003;348:2082-90.

17. Lean ME, Han TS, Prvan T, Richmond PR, Avenell A. Weight loss with high and low carbohydrate $1200 \mathrm{kcal}$ diets in free living women. Eur J Clin Nutr 1997;51:243-8.

18. Yancy WS, Jr., Olsen MK, Guyton JR, Bakst RP, Westman EC. A low-carbohydrate, ketogenic diet versus a low-fat diet to treat obesity and hyperlipidemia: a randomized, controlled trial. Ann Intern Med 2004;140:769-77.

19. Astrup A, Grunwald GK, Melanson EL, Saris WH, Hill JO. The role of low-fat diets in body weight control: a meta-analysis of ad libitum dietary intervention studies. Int J Obes Relat Metab Disord 2000;24:1545-52.

20. Astrup A, Ryan L, Grunwald GK, et al. The role of dietary fat in body fatness: evidence from a preliminary meta-analysis of ad libitum low-fat dietary intervention studies. Br J Nutr 2000;83 Suppl $1: \mathrm{S} 25-32$

21. Wannamethee SG, Shaper AG. Alcohol, body weight, and weight gain in middle-aged men. Am J Clin Nutr 2003;77:1312-7.

22. Koppes LLJ, Twisk JWR, Van Mechelen W, Snel J, Kemper HCG. Cross-sectional and longitudinal relationships between alcohol consumption and lipids, blood pressure and body weight indices. Journal of Studies on Alcohol 2005;66:713-21.

23. Kemper HCGe. Amsterdam Growth and Health Longitudinal Study, a 23-year follow-up from teenager to adult about lifestyle and health. Basel: Karger, 2004.

24. Post GB. Nutrition in Adolescence: A Longitudinal Study in Dietary Patterns from Teenager to Adult. Haarlem: De Vrieseborch, 1989. 
25. Bakker I, Twisk JW, van Mechelen W, Mensink GB, Kemper HC. Computerization of a dietary history interview in a running cohort; evaluation within the Amsterdam Growth and Health Longitudinal Study. Eur J Clin Nutr 2003;57:394-404.

26. NEVO Table. Voorlichtingsbureau voor de voeding (Netherlands Nutrition Centre). Den Haag: Stichting Nederlands Voedingsstoffenbestand (Netherlands Food Composition Chart), 1996.

27. Weiner JS, Lourie JA. Human Biology, a guide to field methods. IBP Handbook. Oxford: Blackwell, 1969:8-29.

28. Twisk JWR. Applied Longitudinal Data Analysis for Epidemiology; a practical guide. Cambridge: Cambridge University Press, 2003.

29. Jebb SA. Dietary strategies for the prevention of obesity. Proc Nutr Soc 2005;64:217-27.

30. van Marken Lichtenbelt WD, Hartgens F, Vollaard NB, Ebbing S, Kuipers H. Body composition changes in bodybuilders: a method comparison. Med Sci Sports Exerc 2004;36:490-7. 


\section{4}

\section{The effects of three diets with various calcium contents on 24-hour energy-expenditure, fat oxidation and adipose tissue mRNA expression of lipid-metabolism related proteins.}

Niels Boon ${ }^{1}$, Gabby B.J. Hul ${ }^{1}$, Nathalie Viguerie ${ }^{2}$, Audrey Sicard ${ }^{2}$, Dominique Langin ${ }^{2}$, Wim H.M. Saris ${ }^{1}$

${ }^{1}$ Nutrition and Toxicology Research Institute Maastricht, University of Maastricht, Maastricht, The Netherlands

${ }^{2}$ Unite de Recherches sur les Obesites, Institut National de la Sante et de la Recherche Medicale (INSERM), Unite 586, Institut Louis Bugnard, Centre Hospitalier Universitaire de Toulouse, Universite Paul Sabatier.

Am J Clin Nutr 2005;82:1244-52. 


\begin{abstract}
Background: Recent evidence from both molecular and animal research and epidemiological investigations indicates that calcium intake may be inversely related to body weight, possibly through alterations in the $1,25-\mathrm{OH}_{2} \mathrm{D}_{3}$ metabolism.

Objective: To test if energy and substrate metabolism and adipose tissue enzyme mRNA expression can be altered by dietary calcium intake in healthy, non-obese human subjects consuming an isocaloric diet.

Design: Twelve healthy males (age: $28 \pm 2(\mathrm{y})$, BMI $\left.25.2 \pm 0.6\left(\mathrm{~kg} / \mathrm{m}^{2}\right)\right)$ received three isocaloric diets (high calcium (1259 $\pm 9 \mathrm{mg} /$ day) /high dairy (high/high), high calcium

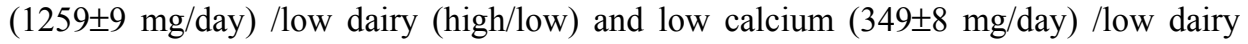
(low/low)) in a randomized, cross-over design. At the end of the 7-day dietary periods 24-hour energy expenditure and substrate metabolism were measured and fat biopsies were obtained for determination of mRNA expression of proteins involved in the lipolytic/lipogenic pathways.

Results: 24-hour energy expenditure was $11.8 \pm 0.3,11.6 \pm 0.3$ and $11.7 \pm 0.3 \mathrm{MJ} / 24 \mathrm{~h}$ in the high/high, high/low and low/low conditions, respectively. The fat oxidation in these conditions was $108 \pm 7,105 \pm 9$ and $100 \pm 5 \mathrm{~g} / 24$-hour. These differences were not statistically significant. mRNA concentrations of $U_{C P}, F A S, G P D H_{2}, H S L$ and PPAR $\gamma$ did not differ. The serum concentration of $1,25-\mathrm{OH}_{2}-\mathrm{D}_{3}$ changed from $175 \pm 16$ to $138 \pm 15,181 \pm 23$ to $159 \pm 19$ and $164 \pm 13$ to $198 \pm 19 \mathrm{pmol} / \mathrm{l}$ in the high/high, high/low and low/low conditions, respectively and was significantly different between the high/high and low/low conditions $(P<0.05)$.

Conclusion: Altering the dietary calcium content for a 7-day period influences neither substrate, nor energy metabolism, nor gene expression of proteins related to fat metabolism, despite significant changes of the $1,25-\mathrm{OH}_{2} \mathrm{D}_{3}$ concentration.
\end{abstract}

Keywords: $1,25-\mathrm{OH}_{2}-\mathrm{D}_{3}$, dietary calcium, energy expenditure, adipose tissue mRNA expression, body weight regulation, substrate metabolism. 


\section{Introduction}

The prevalence of obesity has increased markedly during the past two decades, making obesity an important risk factor for the development of type 2 diabetes, various types of cancer, and cardiovascular complications. In recent years, an inverse relation between dietary calcium and Body Mass Index (BMI) was repeatedly observed (1-8). Some intervention studies also showed that dietary calcium may have weight-lowering effects and in addition, an even stronger effect was observed with dairy sources of calcium (912).

However, the mechanism is still unclear. A hypothesis to explain this relation was provided by Zemel et al. (13); With an increased concentration of $1,25-\mathrm{OH}_{2} \mathrm{D}_{3}$ in cultures of human adipocytes and in transgenic mice, acute increases of the intracellular calcium concentration were observed $(14,15)$. This increased level of $\mathrm{Ca} 2+$ in the adipocytes lowered lipolysis and stimulated lipogenesis. Lowering dietary calcium intake leads to an increase in the serum concentration of $1,25-\mathrm{OH}_{2} \mathrm{D}_{3}$ within a few days (16). In this way, a low dietary calcium intake may lead to a higher body weight by changing the balance of lipolysis and lipogenesis in adipose tissue through an increase in serum $1,25-\mathrm{OH}_{2} \mathrm{D}_{3}(1)$.

$1,25-\mathrm{OH}_{2} \mathrm{D}_{3}$ is an important regulator of a large number of genes (17). Among the genes regulated by $1,25-\mathrm{OH}_{2} \mathrm{D}_{3}$ are also genes that are either related to fat breakdown and storage (HSL (hormone sensitive lipase), GPDH2 (glycerol phosphate dehydrogenase), $F A S$ (fatty acid synthase)) or adipocyte differentiation (PPAR $\gamma$ (peroxisome proliferator activated receptor gamma)) (18-22). Furthermore, 1,25-OH2-D3 decreases the mRNA expression of $U C P 2$ (23), which is correlated with basal metabolic rate (18). If changes in serum $1,25-\mathrm{OH}_{2} \mathrm{D}_{3}$ are paralleled by changes in the expression of these genes, this may provide more insight on how calcium intake affects body weight through changes in lipogenesis, lipolysis and energy expenditure.

The first well controlled experimental trial looking at the effects of calcium intake on energy and fat metabolism in weight stable subjects was published by Melanson et al., who observed a positive correlation between 24-hour- and sleeping fat oxidation and calcium intake, but they did not correct for protein intake (9). Furthermore, in most of the epidemiological and dietary intervention studies performed in humans mentioned here, the investigators have not corrected for protein intake $(3,4,9,24-26)$, which has been shown to have weight lowering effects (27-31).

These data prompted us to investigate the effect of three isocaloric diets with a fixed macronutrient composition and different concentrations of calcium on 24-hour energy expenditure and 24-hour fat oxidation in vivo in humans. We hypothesized that a higher calcium intake would increase these parameters and an additive effect may be observed of low-fat dairy. In order to study potential effects on a molecular level, mRNA expression of different genes related to fat metabolism (i.e. $U C P_{2}, F A S, G P D H_{2}, H S L$ and $P P A R \gamma$ in adipose tissue was investigated as well. 


\section{Subjects and methods}

\section{Experimental Subjects}

Twelve non-trained, healthy males were recruited for participation in this study through advertisements in local newspapers. This study was approved by the local ethical committee of the University of Maastricht and the Academic Hospital of Maastricht and after the subjects had received a written and oral explanation of the procedures to be followed in this project, their informed consent was obtained. Furthermore, the habitual energy-, micro- and macronutrient intake of the subjects was assessed by using 3-day food intake diaries, before the start of the experiment. Subjects were provided with a digital kitchen balance to allow them to make a more accurate estimation of their habitual food intake and the macro- and micronutrient composition of these habitual diets was calculated from these food records using the Dutch food composition table (32). Habitual physical activity of the subjects was also determined; in order to assure that none of the subjects spent more than three hours per week in heavy physical exercise. And finally, before the start of the first dietary intervention period body composition and maximal aerobic capacity were determined as follows:

Table 1: Physical characteristics of the male subjects $(n=12)$

\begin{tabular}{lcc}
\hline & \multicolumn{2}{c}{ Range } \\
\hline Age $(\mathrm{y})$ & $28 \pm 2$ & $20-40$ \\
Height $(\mathrm{m})$ & $1.78 \pm 0.02$ & $1.65-1.92$ \\
Weight $(\mathrm{kg})$ & $80.0 \pm 0.6$ & $65.5-95.9$ \\
BMI $(\mathrm{kg} / \mathrm{m} 2)$ & $25.2 \pm 0.6$ & $21.2-27.9$ \\
Body Fat $(\%)$ & $22.1 \pm 1.6$ & $9.0-31,9$ \\
Wmax $(\mathrm{W})$ & $271 \pm 9$ & $233-336$ \\
VO2max $(1 / \mathrm{min})$ & $3.5 \pm 0.1$ & $3.0-4.5$ \\
$\mathrm{Hfmax}(\mathrm{bpm})$ & $193 \pm 3$ & $175-203$ \\
$1,25-\mathrm{OH}_{2} \mathrm{D}_{3}(\mathrm{pmol} / \mathrm{l})$ & $193 \pm 27$ & $119-447$ \\
\hline
\end{tabular}

All values are mean \pm SEM; BMI: Body Mass Index Wmax: Maximal workload; VO2max: Maximal oxygen ; onsumption; Hfmax: Maximal heartrate; Bpm: beats per minute; 1,25- $\mathrm{OH}_{2} \mathrm{D}_{3}$ : Baseline serum concentration of $1,25-\mathrm{OH}_{2} \mathrm{D}_{3}$

\section{Maximal aerobic capacity and anthropometrical measurements}

\section{Maximal exercise test}

At least one week before the first stay in the respiration chamber, maximum oxygen uptake $\left(\mathrm{VO}_{2} \max \right)$, maximum workload (Wmax) and maximal heart rate (Hfmax) were determined on an electronically braked cycle ergometer (Lode Excalibur, Groningen, the Netherlands) during an incremental exhaustive exercise test. During this test, oxygen uptake was measured using indirect calorimetry (Oxycon- $\beta$, Mijnhardt, Mannheim, Germany) and heart rate was determined with a heart rate monitor (Polar Sporttester, Polar Electro, Kempele, Finland). Exercise was started at $100 \mathrm{~W}$ for 5 minutes and the power output was increased by $50 \mathrm{~W}$ every 2.5 minutes consequently until subjects reached a heart rate of 160 . Thereafter, workload was increased by $25 \mathrm{~W}$. 
We instructed our subjects to continue until exhaustion and in order to calculate the maximum power output, we used the following formula:

$$
\mathrm{W}_{\max }=\mathrm{W}_{\text {out }}+(\mathrm{t} / 150) \times \partial \mathrm{W}
$$

in which Wout is the highest workload completed by the subject, $\mathrm{t}$ is the time (in seconds) performed on the last workload and $\partial \mathrm{W}$ is the final uncompleted load increment. The maximal power output was determine the workload at which subjects had to exercise for 45 minutes during their three consecutive stays in the respiration chamber.

\section{Body composition and anthropometrical measurements}

In order to assure an accurate description of body composition, this was determined using the 3-component model with water by Siri (33), which is a method that combines determination of total body water with deuterium dilution and estimation of whole body density $(\mathrm{Db})$ by underwater weighing. The exact details of this method have been described in detail elsewhere (34).

\section{Experimental design}

All twelve subjects underwent three 7-day dietary interventions in a randomized, crossover design; a high calcium, high dairy (high/high) diet; a high calcium, low dairy (high/low) diet and a low calcium, low dairy control diet (low/low), each followed by a wash out period of 7-14 days. The subjects consumed these diets at home during the first 5.5 days of the intervention periods and during the last 36 hours of each dietary intervention, when the subjects were studied in the respiration chamber.

Blood samples were obtained in the fasted state on the first day of each dietary intervention period ( $\mathrm{t}=0$ days), on the evening the subjects entered the respiration chamber in the postprandial state ( $\mathrm{t}=5.5$ days) and the final blood sample of each period was obtained in the fasted state when subjects left the respiration chamber $(\mathrm{t}=7$ days). Fat biopsies were obtained in the fasted state at baseline and on the three occasions that the subjects left the respiration chamber; at the end of the three dietary intervention periods.

Diets

During the 5.5-day periods preceding their 36-hour stay in the respiration chamber, subjects were provided with three different diets for consumption at home. All food items were consumed as breakfast, lunch, dinner and three snacks. From the dinner on day 6 onward, all food was consumed in the respiration chamber. During these respiration chamber experiments, subjects received breakfast, lunch and dinner at 7:30h, 12:30h and 18:00h, and snacks at 10:00h, 15:00h and 20:30h. These diets were composed so that their macro- and micronutrient composition resembled the average consumption in the Netherlands. However, we choose to use a relatively high protein content, in order to ensure that the protein balance was equally positive in all experimental conditions, because a high protein diet may affect body weight (29). The macro- and micronutrient composition of these diets was calculated using the Dutch food composition table (32). The energy content of the diets during the first 5.5 days of each dietary intervention was determined by using the Harris and Benedict equation (35) for men, multiplying the outcome of this calculation by 1.6 to adjust for daily physical activity. 
The characteristics of the experimental isocaloric diets was as follows:

- High calcium, High dairy diet (high/high): This diet contained $50 \%$ carbohydrate, $20 \%$ protein and $30 \%$ fat. Low-fat dairy was used as the main source of protein. The calcium content of this diet was 1200-1300 mg/day;

- High calcium, Low dairy diet (high/low): In this diet, non-dairy sources of protein (animal and vegetable protein) were used to match the contribution to the total energy intake of protein, fat as well as carbohydrate to diet 1; The calcium content of this diet was increased to the same value as the calcium content of diet 1 (i.e. 1200-1300 mg/day) by supplementing with calcium carbonate (CalciChew, Christiaens BV, Breda, The Netherlands) (i.e. a nondairy source of calcium).

- Low calcium, Low dairy diet (low/low): The composition of this diet was exactly similar to diet 2 , but without the calcium carbonate supplementation. The calcium content of this diet was $300-400 \mathrm{mg} /$ day.

Subjects received a written and oral instruction every time when the diets were handed out, along with a meal-to-meal description of all food items that were to be consumed. All food items were weighed and packed at the research facility and were handed out to the subjects on days 1 and 4 of the dietary intervention periods. Subjects were instructed to write down all deviations from the diets and to report all problems immediately to the researcher. Furthermore, compliance to the diets was also checked with interviews, subjects were also instructed to return all the items they did not consume on the evening they reported to the laboratory for their 36-hour stay in the respiration chamber. These returned food items were not included in the calculation of the total dietary intake during the experimental periods. In general, no major deviations from the diets were reported, i.e. these deviations did not affect the macronutrient composition and calcium content of the diets.

Because it has been shown that deviations from energy balance (i.e. the absolute difference between energy intake (EI) and energy expenditure (EE)) can significantly alter substrate metabolism (36), it was assured that the subjects were in energy balance (here defined as a maximal difference between EI and EE of less than $0.5 \mathrm{MJ} / 24$ hours) during the measurements of 24-hour energy expenditure and fat oxidation. In order to achieve this, at 07:00h, sleeping metabolic rate (SMR, defined as the lowest mean EE during three consecutive hours between 23:00 and 07:00h,) during the first night was calculated as previously described by Schrauwen et al. (37) and multiplied with an activity index (PAI) of 1.7, which is an activity level that has previously been observed in studies with a comparable exercise regimen (38). Furthermore, at 16:00 and 20:00h, EE was calculated again in order to adjust EI.

\section{Indirect calorimetry}

A respiration chamber was used in order to accurately determine energy expenditure and substrate oxidation (39). This respiration chamber is a $14 \mathrm{~m}^{3}$ room and it is equipped with a bed, chair, radio, telephone, intercom, a computer with Internet connection, sink and toilet. Furthermore, the air in the respiration chamber is ventilated at a rate of 70-80 $1 * \min ^{-1}$. This ventilation rate is measured with a dry-gas meter (Schlumberger, type G6, The Hague, The Netherlands). The concentrations of oxygen and carbon dioxide are measured using paramagnetic $\mathrm{O}_{2}$ analyzers (Hartmann \& Braun, type Magnos G6, Hartmann \& Braun, Frankfurt, Germany; Servomex, type OA 184A, UK) and infrared $\mathrm{CO}_{2}$ analyzers (Hartmann \& Braun, type Uras 3G, Hartmann \& Braun, Frankfurt, Germany). During each 15-minute period, six samples of outgoing air for each chamber, 
one sample of fresh air, zero gas and calibration gas are measured. The gas samples to be measured are selected by a computer, which also stores and processes the data.

\section{Calculations}

In order to calculate 24-hour EE, this value was calculated from $\mathrm{VO}_{2}$ and $\mathrm{VCO}_{2}$ values obtained in the period from 07:00h until 07:00h the next day using the Weir formula (40) and along with the data on urinary nitrogen losses (see also biochemical methods), these $\mathrm{VO}_{2}$ and $\mathrm{VCO}_{2}$ values were used to calculate carbohydrate, fat and protein oxidation with the equations of Brouwer (41):

Protein oxidation $(\mathrm{g} / \mathrm{d})=6.25 \times \mathrm{N}$

Fat oxidation $(\mathrm{g} / \mathrm{d})=1.718 \times \mathrm{VO}_{2}-1.718 \times \mathrm{VCO}_{2}-0.315 \times \mathrm{P}$

Carbohydrate oxidation $(\mathrm{g} / \mathrm{d})=4.17 \times \mathrm{VCO}_{2}-2.965 \times \mathrm{VO}_{2}-0.390 \times \mathrm{P}$

Where $\mathrm{N}$ is the total nitrogen excreted in urine ( $\mathrm{g} /$ day)

$\mathrm{VO}_{2}$ is the oxygen consumption ( $1 /$ day)

$\mathrm{VCO}_{2}$ is the carbon dioxide production (1/day)

$\mathrm{P}$ is protein oxidation ( $\mathrm{g} /$ day)

Consequently, substrate balances were calculated by subtracting the calculated values of macronutrient oxidation from the calculated intake of these macronutrients during the 24-hour stay in the respiration chamber.

At daytime, subjects were instructed not to perform any strenuous exercise apart from the 45 minutes of moderate intensity (50\% of maximal workload (Wmax)) cycling exercise at 11:00h. Furthermore, they were told not to sleep at daytime and they were asked to go to bed at approximately $23: 00 \mathrm{~h}$ throughout all three respiration chamber experiments and they were woken up at 07:00h.

EE and substrate oxidation were calculated for the four individual periods listed below:

-Sleeping metabolic rate (SMR, defined as the lowest mean EE during three consecutive hours between 23:00 and 07:00h, RQ was also determined during this period);

-Energy expenditure and substrate oxidation during sleep (EEsleep and RQsleep, defined as the average energy expenditure and RQ values from 23:00 until 07:00h);

-Resting energy expenditure and RQ (EErest and RQrest, defined as the average energy expenditure from 07:00 until 23:00h, except for the 45 minutes of exercise);

-Energy expenditure and RQ during exercise (EEexercise and RQexercise defined as the average energy expenditure and RQ during exercise at 50\% Wmax).

Finally, the Physical Activity Index (PAI) was also calculated for the three different experiments in every subject. This was done by dividing the 24-hour EE by the SMR during the second night of the respiration chamber measurements.

\section{Biochemical methods}

After blood samples were drawn they were centrifuged at $4.000 \times \mathrm{g}$ for 10 minutes, aliquots of EDTA plasma and serum were frozen in liquid nitrogen and stored at $-80^{\circ} \mathrm{C}$ until further analysis. Total plasma FFA, glucose, free glycerol and Ca2+ concentrations in the blood samples were measured using standard enzymatic techniques automated on Cobas FARA and MIRA centrifugal analyzers at $340 \mathrm{~nm}$ (for FFA: FFA-C test kit, Wako Chemicals, Neuss, Germany; for glucose: Roche Unikit III, Hoffman-LaRoche Inc., Basel, Switzerland; for free glycerol: Roche Molecular Biochemicals, Mannheim, Germany, for $\mathrm{Ca} 2+$ : Calcium CP, ABX pentra, Montpellier, France). Plasma insulin was measured using a specific double antibody RIA for human insulin (Kabi Pharmacia, Uppsala, Sweden) and $1,25-\mathrm{OH}_{2} \mathrm{D}_{3}$ was determined using a monoclonal antibody RIA (ImmunoDiagnostic Systems Ltd., Boldon, United Kingdom). 
To allow us to calculate nitrogen excretion, 24-hour urine was collected while the subjects were in the respiration chamber from the second voiding on the first morning until the first voiding on the second morning in containers with $10 \mathrm{~mL}$ of a $4 \mathrm{M} \mathrm{H}_{2} \mathrm{SO}_{4}$ solution to prevent nitrogen losses through evaporation. Volume of the 24-hour urine was measured and samples of the 24 -hour urine were stored at $-20^{\circ} \mathrm{C}$ until later analysis for nitrogen content.

\section{Quantification of messenger RNAs in human adipose tissue biopsies using RT-qPCR}

After fat biopsies were obtained using a percutaneous needle attached to a vacuum syringe, blood and connective tissue were washed off with a sterile $0.9 \% \mathrm{NaCl}$ solution, consequently fat tissue was weighed and homogenized in $1 \mathrm{~mL}$ of a $1 \%$ solution of $\beta$ mercaptoethanol in RLT-buffer (RNeasy Mini kit, Qiagen Inc) per $1000 \mathrm{mg}$ of fat tissue, frozen immediately in liquid nitrogen and stored at $-80^{\circ} \mathrm{C}$ until further analysis. Total RNA was extracted from adipose tissue biopsies using the RNeasy Mini kit (Qiagen, Courtaboeuf, France). First-strand cDNAs were first synthesized from $200 \mathrm{ng}$ total RNA in the presence of 100 units of Superscript II reverse transcriptase (Invitrogen, Cergy Pontoise, France) using random hexamer primers (Promega, Charbonnières, France). Real-time quantitative polymerase chain reactions (qPCR) were performed on a GeneAmp 7000 Sequence Detection System (Applied Biosystems, Foster City, CA, USA). Ten ng of cDNA were used as template for real-time PCR. The thermal cycler parameters for the real-time PCR were $2 \mathrm{~min}$ at $50^{\circ} \mathrm{C}$ followed by 40 cycles with $10 \mathrm{sec}$ at $95^{\circ} \mathrm{C}$ and $1 \mathrm{~min}$ at $60^{\circ} \mathrm{C}$. For each primer pair, a standard curve was obtained using serial dilutions of human adipose tissue cDNA prior to mRNA quantitation. For HSL a set of primers (Genset - Proligo France, Paris, France) was designed using the software Primer Express 1.5 (Applied Biosystems, Foster City, CA, USA) and used at a final concentration of $900 \mathrm{nM}$ with SYBR-Green based chemistry. A dissociation curve was generated at the end of the PCR cycles to verify that a single gene product was amplified. For $U C P_{2}, F A S, G P D H_{2}$ and $P P A R \gamma$ the Taqman approach was used. Both primers and TaqMan ${ }^{\mathrm{TM}}$ probes were obtained from Applied Biosystems (Foster City, CA, USA). The probes were labeled with a reporter dye (FAM) on the $5^{\prime}$ end. The probe for $18 \mathrm{~S}$ ribosomal RNA was labeled with the reporter dyes $\mathrm{VIC}^{\mathrm{TM}}$ and TAMRA (Applied Biosystems, Foster City, CA, USA) on the 5' end and the 3 ' end, respectively. For Taqman assays, because of very high specificity of the method, check for non-specific product formation with dissociation curve is not needed. We used $18 \mathrm{~S}$ rRNA as control to normalize gene expression using the Ribosomal RNA Control TaqMan $^{\mathrm{TM}}$ Assay kit (Applied Biosystems, Foster City, CA, USA). All reactions were performed in duplicate.

\section{Statistical analysis}

Statistical power analysis using variance data from previously published, similar research, in which a SEM of the $24 \mathrm{~h}$ energy expenditure of $0.4 \mathrm{MJ}$ and a SEM of the $24 \mathrm{~h}$ RQ of 0.01 were observed (42), indicated that a minimum of 12 subjects was required in order to detect a 0.02 decrease in RQ values and a $10 \%$ increase in energy expenditure between the high/high and low/low diets at a significance level of $95 \%$. This would represent a difference in fat oxidation of about $20 \mathrm{~g}$ per day and a difference in energy expenditure of about $1200 \mathrm{~kJ}$ per day at an energy expenditure level of $12 \mathrm{MJ}$ per day. These differences in RQ values and energy expenditure were based on the 
results of Melanson et al. who found even stronger effects of acute calcium intake on $24 \mathrm{~h}$ fat oxidation in a less well controlled study (9).

Possible significant differences in substrate and energy metabolism induced by the three different diets were calculated by using a two factor ANOVA and a Scheffé test was used for post-hoc analysis. Differences over time for the serum $1,25-\mathrm{OH}_{2}-\mathrm{D}_{3}$ concentration were tested for significance with an ANOVA repeated measures analysis. When a significant group $\mathrm{X}$ time interaction was observed, a Scheffé post-hoc was used, in order to determine the differences between the three dietary conditions on specific time points. Statistical difference was set at $P<0.05$. All data are presented as mean \pm SEM. SPSS for Windows version 12.0.1 (Chicago, IL) was used for the statistical analysis.

\section{Results}

\section{Subject characteristics}

The average age $(\mathrm{y})$ and BMI $\left(\mathrm{kg} / \mathrm{m}^{2}\right)$ of the subjects was $28 \pm 2$ and $25.2 \pm 0.6$ (all values are presented as mean \pm SEM) (table 1$)$.

\section{Habitual dietary intake}

The subjects had an average energy consumption of $12.6 \pm 1.0 \mathrm{MJ}$ per day, which was consumed as $14.8 \pm 0.9 \%$ of protein, $45.9 \pm 2.8 \%$ from carbohydrate and $35.7 \pm 2.2 \%$ from fat. The habitual daily calcium intake of these subjects was $1027 \pm 82 \mathrm{mg}$ and dietary fiber intake of the subjects was $21.2 \pm 1.9 \mathrm{~g}$ per day (table 2).

Table 2: Energy (MJ/day) and macronutrient composition, calcium (mg/day) and dietary fiber (g/day) content of habitual and experimental diets ( 7 days $)(n=12)$

\begin{tabular}{lcccc}
\hline \multicolumn{5}{c}{ Diet } \\
\hline Energy intake & Habitual & High/High & High/Low & Low/Low \\
\%PRO & $12.6 \pm 1.0$ & $12.3 \pm 0.3$ & $12.0 \pm 0.6$ & $12.3 \pm 0.3$ \\
\%CHO & $14.8 \pm 0.9$ & $19.9 \pm 0.1$ & $19.7 \pm 0.1$ & $19.8 \pm 0.1$ \\
\%FAT & $45.9 \pm 2.8^{1}$ & $50.0 \pm 0.1$ & $49.9 \pm 0.1$ & $49.9 \pm 0.1$ \\
Calcium & $35.7 \pm 2.2^{2}$ & $29.9 \pm 0.1$ & $30.2 \pm 0.1$ & $30.1 \pm 0.1$ \\
Dietary fiber & $1027 \pm 82^{3}$ & $1259 \pm 9$ & $1259 \pm 9$ & $349 \pm 8^{4}$ \\
\hline
\end{tabular}

All values are mean \pm SEM; ${ }^{1}$ Significantly different from experimental diets $(\mathrm{P}<0.0001)$; ${ }^{2}$ Significantly different from experimental diets $(\mathrm{P}<0.01)$; ${ }^{3}$ Significantly different from experimental diets $(\mathrm{P}<0.0001$ vs. low/low, $\mathrm{P}<0.01$ vs. high/high and high/low); ${ }^{4}$ Significantly different from high/high and high/low diets $(\mathrm{P}<0.0001)$ 


\section{Experimental diets}

All subjects completed the three different dietary regimens without any adverse effects of the diets, except for one subject who reported after his first 5.5-day dietary run-in (high/low diet) that he had not consumed all of the food items provided, since he felt he was overeating. Since the macronutrient composition and calcium content of the diet he had consumed were in line with the experimental diets, the data from this experiment were included in the final analysis. His energy intake during the two following dietary intervention periods was adjusted according to his energy expenditure during the first respiration chamber experiment. The average energy intake during the 7 days of the dietary interventions was $12.3 \pm 0.3,12.0 \pm 0.6$ and $12.3 \pm 0.3 \mathrm{MJ} / \mathrm{day}$ for the high/high, high/low and low/low diets respectively. The experimental diets only differed in calcium concentration $(P<0.0001$, low/low vs. high/high and high/low $)$. All of the experimental diets contained significantly more dietary fiber and carbohydrates $(P<0.0001)$ and significantly less fat $(P<0.01)$ than the subjects' habitual diets (table 2$)$. The high calcium diets contained significantly more calcium than the habitual diet $(P<0.01)$ and the low calcium diet contained significantly less calcium $(P<0.0001)$. The energy and protein content was not significantly different between any of the diets (table 2). The dietary tool that has been used in the present investigation does not allow for a very accurate determination of vitamin $\mathrm{D}$ intake, but the average intake was approximately $16 \pm 8 \mathrm{I}$.U./day during the three experimental diets while the habitual intake was $28 \pm 8$ I.U./day. This difference between the experimental and habitual diets was not statistically significant. In order to test if the order in which the diets were given had an effect on the measurements of energy and substrate metabolism, all analyses were also performed with order of diet as a factor. No effects of order of the dietary intervention were observed.

\section{Metabolic measurements}

In all experiments, energy balance was achieved ([EI-EE]<0.5 MJ). On average, the absolute deviation from energy balance was $0.2 \pm 0.0$ (high/high), $0.3 \pm 0.1$ (high/low) and $0.2 \pm 0.1$ (low/low) $\mathrm{MJ} /$ day during the 24-hour measurements in the respiration chamber. The total 24-hour energy expenditure was $11.8 \pm 0.3,11.6 \pm 0.3$ and $11.7 \pm 0.3 \mathrm{MJ} / 24 \mathrm{~h}$ in the high/high, high/low and low/low conditions, respectively. These differences were not statistically different. The energy expenditure during the other periods (EESMR, EEsleep, EErest and EEexercise) and the activity index PAI were not statistically different, either (table 3).

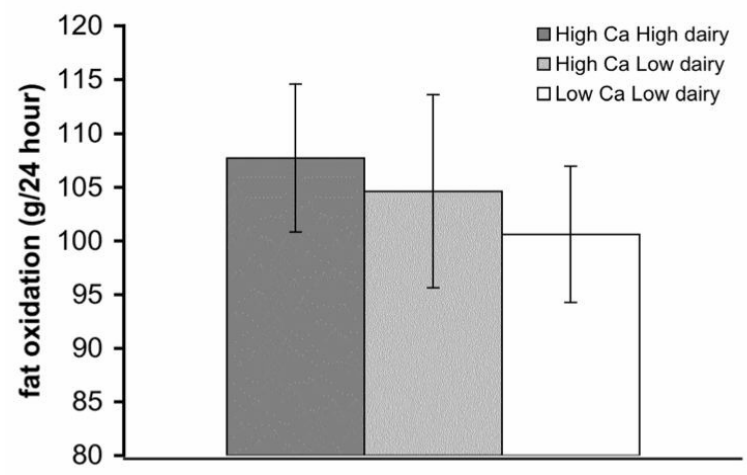

Figure 1: Twenty-four hour fat oxidation ( $\mathrm{g} / 24$ hour).( $\mathrm{n}=12)$. None of these differences were statistically significant. 
The average 24-hour RQ was $0.85 \pm 0.01,0.85 \pm 0.01$ and $0.86 \pm 0.01$ and the average 24hour fat oxidation in the three conditions was $108 \pm 7,105 \pm 9$ and $100 \pm 6 \mathrm{~g} / \mathrm{day}$, in the high/high, high/low and low/low conditions, respectively (figure 2). These differences were not statistically different. The average RQ during SMR in the three different dietary conditions was not statistically different either $(0.82 \pm 0.01,0.81 \pm 0.02$ and $0.82 \pm 0.01$, respectively). No significant differences in RQ were observed during the other periods (sleep, rest nor exercise) (table 3).

Due to the relatively high dietary protein intake, a positive 24-hour protein balance (47.5 $\pm 4.6,40.3 \pm 4.4$ and $38.7 \pm 5.0 \mathrm{~g}$ in the high/high, high/low and low/low conditions, respectively) was observed in all three experimental conditions. 24-hour fat balance was $-16.1 \pm 6.0,-10.3 \pm 7.6$ and $-8.4 \pm 5.2 \mathrm{~g}$ in the high/high, high/low and low/low conditions, respectively and 24-hour carbohydrate balance was $11.6 \pm 15.2,29.6 \pm 19.6$ and $8.6 \pm 14.1 \mathrm{~g}$ in the high/high, high/low and low/low conditions, respectively. No significant differences in substrate balance were observed between the three diets (table 3).

Table 3: Different components of energy expenditure $(\mathrm{kJ} / \mathrm{min})(\mathrm{n}=12)$

\begin{tabular}{|c|c|c|c|}
\hline Energy expenditure (kJ/min) & High/High & High/Low & Low/Low \\
\hline 24-hour EE & $8.19 \pm 0.21$ & $8.04 \pm 0.20$ & $8.11 \pm 0.20$ \\
\hline $\mathrm{EE}_{\text {sleep }}$ & $5.58 \pm 0.16$ & $5.54 \pm 0.13$ & $5.55 \pm 0.16$ \\
\hline EE $_{\text {rest }}$ & $8.04 \pm 0.22$ & $7.86 \pm 0.21$ & $7.86 \pm 0.19$ \\
\hline $\mathrm{EE}_{\text {exercise }}$ & $40.24 \pm 1.36$ & $38.45 \pm 1.47$ & $39.39 \pm 1.39$ \\
\hline PAI & $1.60 \pm 0.02$ & $1.59 \pm 0.03$ & $1.61 \pm 0.04$ \\
\hline \multicolumn{4}{|l|}{ RQ } \\
\hline 24-hour RQ & $0.85 \pm 0.01$ & $0.85 \pm 0.01$ & $0.86 \pm 0.01$ \\
\hline $\mathrm{RQ}_{\text {sleep }}$ & $0.81 \pm 0.01$ & $0.82 \pm 0.01$ & $0.83 \pm 0.01$ \\
\hline $\mathrm{RQ}_{\text {rest }}$ & $0.87 \pm 0.01$ & $0.87 \pm 0.01$ & $0.87 \pm 0.01$ \\
\hline$R Q_{\text {exercise }}$ & $0.90 \pm 0.01$ & $0.90 \pm 0.01$ & $0.91 \pm 0.01$ \\
\hline \multicolumn{4}{|c|}{$\begin{array}{l}\text { Absolute deviation from energy balance } \\
(\mathrm{MJ} / 24 \mathrm{~h})\end{array}$} \\
\hline Energy intake (MJ) & $11.7 \pm 0.3$ & $11.6 \pm 0.3$ & $11.6 \pm 0.3$ \\
\hline Energy expenditure (MJ) & $11.8 \pm 0.3$ & $11.6 \pm 0.3$ & $11.7 \pm 0.3$ \\
\hline Absolute deviation [EI-EE] & $0.2 \pm 0.0$ & $0.3 \pm 0.1$ & $0.2 \pm 0.1$ \\
\hline \multicolumn{4}{|l|}{ Substrate balances $(\mathrm{g} / 24 \mathrm{~h})$} \\
\hline Protein & $+47.5 \pm 4.6$ & $+40.3 \pm 4.4$ & $+38.7 \pm 5.0$ \\
\hline Fat & $-16.1 \pm 6.0$ & $-10.3 \pm 7.6$ & $-8.4 \pm 5.2$ \\
\hline Carbohydrate & $+11.6 \pm 15.2$ & $+29.6 \pm 19.6$ & $+8.6 \pm 14.1$ \\
\hline
\end{tabular}

All values are mean \pm SEM; None of these differences were statistically significant

No differences between the three diets were observed in the plasma calcium, FFA, glucose, insulin or glycerol concentrations. All values were within the normal range. The serum $1,25-\mathrm{OH}_{2} \mathrm{D}_{3}$ concentrations at $\mathrm{t}=0$ were not significantly different between the three interventions. The serum concentration of $1,25-\mathrm{OH}_{2} \mathrm{D}_{3}$ decreased from $175 \pm 16$ to $138 \pm 15 \mathrm{pmol} / 1$ during the high/high condition, decreased from $181 \pm 23$ to $159 \pm 19$ $\mathrm{pmol} / \mathrm{l}$ in the high/low condition and increased in the low/low condition, from $164 \pm 13$ to $198 \pm 19 \mathrm{pmol} / \mathrm{l}$. A significant group $\times$ time interaction was observed $(\mathrm{P}<0.05)$. The serum concentration of $1,25-\mathrm{OH}_{2} \mathrm{D}_{3}$ was significantly different between the high/high and low/low conditions at $\mathrm{t}=7(\mathrm{P}<0.05)$. Furthermore, the change in serum $1,25-\mathrm{OH}_{2} \mathrm{D}_{3}$ concentration was $-39 \pm 13,-22 \pm 27$ and $33 \pm 15 \mathrm{pmol} / 1$ for the high/high, high/low and 
low/low conditions, respectively. The difference in change was significantly different between the high/high and low/low conditions $(\mathrm{P}<0.05)$. No differences were observed between the high/low and the other two conditions (figure 2).

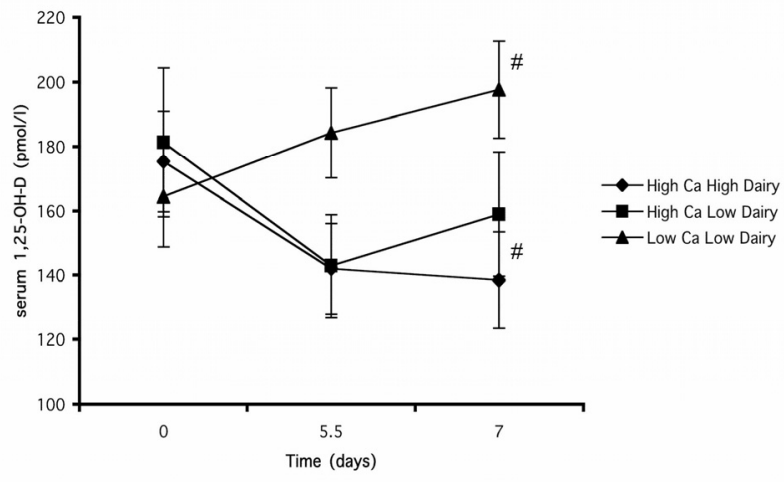

Figure 2: Serum 1,25-OH2-D3 concentrations $(\mathrm{pmol} / \mathrm{l})$. $(\mathrm{n}=12)$. \# Denotes a significant difference in concentration when the high calcium high dairy diet is compared to the low calcium low dairy diet. $(\mathrm{P}<0.05)$

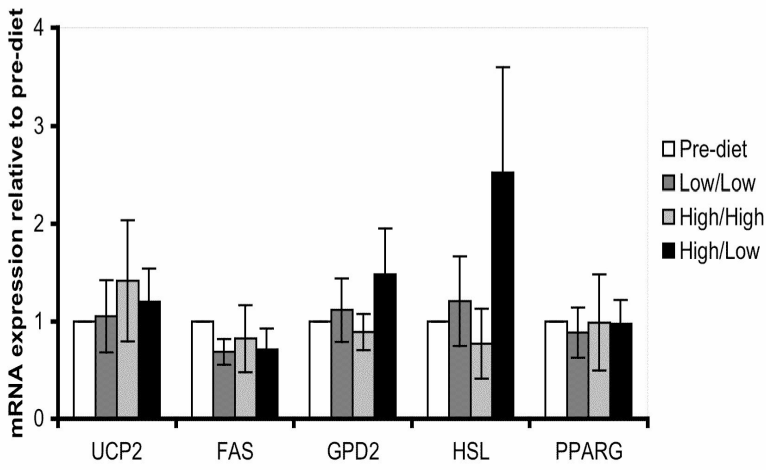

Figure 3: Adipose tissue uncoupling protein $2\left(\mathrm{UCP}_{2}\right)$, fatty acid synthase (FAS), hormone sensitive lipase (HSL), peroxisome proliferator activated receptor gamma (PPARG) and glycerol phosphate dehydrogenase $\left(\mathrm{GPDH}_{2}\right)$ mRNA expression. $(n=10)$. None of these differences were statistically significant.

The mRNA concentrations in adipose tissue were determined for 10 subjects only, because for 2 subjects, no complete sets of biopsies could be obtained due to their relatively low body fat percentage. No differences were observed in the mRNA concentration of $U C P_{2}, F A S, G P D H_{2}, H S L$ or $P P A R \gamma$ between the three diets (figure 3).

\section{Discussion}

In this carefully controlled dietary intervention study, no differences in energy or substrate metabolism were observed between three diets with varying calcium and dairy protein contents, despite significant changes in the serum $1,25-\mathrm{OH}_{2} \mathrm{D}_{3}$ concentration. We did not see any differences in gene expression of five genes involved in the lipogenic and lipolytic pathways, either.

Since some epidemiological investigations do show the long-term effects of an altered $\mathrm{Ca}^{2+}$-intake, it may be argued that the duration of the intervention period was not long 
enough to induce the necessary adaptations of the $1,25-\mathrm{OH}_{2} \mathrm{D}_{3}$ metabolism. However, we observed significant differences between the three diets for this hormone within 7 days, which is in line with previous research (43) and this hormone has been shown to have immediate effects on lipolysis $(22,23,44,45)$, so the significant changes in 1,25$\mathrm{OH}_{2}-\mathrm{D}_{3}$ that were observed in this study should have induced the metabolic changes that we hypothesized. Nonetheless, other adaptations to a high calcium and dairy diet may also occur that take longer than 7 days. The short duration of this intervention trial did not allow us to measure the effects of such longer-term adaptations.

It may also be argued that we have studied the effects of calcium depletion rather than the effects of calcium supplementation because of the already high and possibly optimal calcium intake of our subjects. But this is contradicted by our data, because both the high/high and low/low conditions induced a significant change from the baseline values of the serum $1,25-\mathrm{OH}_{2} \mathrm{D}_{3}$ concentration in these subjects with a high habitual calcium intake. Along with the results from two other recent investigations in which no relation between $1,25-\mathrm{OH}_{2} \mathrm{D}_{3}$ and body weight was observed $(46,47)$, our results indicate that the $1,25-\mathrm{OH}_{2} \mathrm{D}_{3}$ metabolism may not play a significant role in the relation of calcium with body weight, which is not in line with previous studies investigating the relation between calcium intake, $1,25-\mathrm{OH}_{2} \mathrm{D}_{3}$ and substrate and energy metabolism (10, 48-51). However, part of this research showing significant effects of altering calcium intake on body weight was performed in rodents and the results may not carry over to the human situation. The high-calcium diet induced a 1.2 fold increase in calcium intake, whereas increases of up to 2-fold were observed in the animal studies $(11,12)$. Furthermore, the results of the various experiments performed in cell cultures are not directly applicable to whole body human metabolism because the intracellular calcium concentrations in these experiments $(14,22,23,45,52,53)$ were manipulated directly by calcium channel and vitamin $\mathrm{D}$ receptor agonists and not through an altered dietary intake of calcium and therefore do not reflect the normal physiological situation. Thus, it seems that the results from these cell culture and animal studies are not directly applicable to the human in vivo situation.

An explanation for the discrepancy with the observational research and our results may be that due to the larger statistical power in epidemiological investigations, the differences in body weight and body composition caused by subtle differences in energy and substrate metabolism that are expected from changes in calcium intake are more likely to be detected $(3,4,25,26,54-60)$. Recently, Jacobsen et al. did not observe any differences in substrate and energy metabolism either, using a comparable study design (61). Based upon a post-hoc power analysis, it was calculated that in order to reach significant differences in energy expenditure with the variance and differences observed between groups in the present investigation, we should include at least 43 subjects. This shows that 7-day changes in dietary calcium content may not have a robust effect on neither energy expenditure, nor fat oxidation, which is in line with recent work from Shapses et al. (62). However, if the observed differences would sustain for a prolonged period, they may contribute to a significant effect on body weight. For example, if the effects on fat oxidation observed in this project would last for one year, they may account theoretically for a difference in body weight of approximately $3.0 \mathrm{~kg}$ (assuming an additional fat oxidation of $8 \mathrm{~g} /$ day and with the assumption that an additional 38000 $\mathrm{kJ}$ needs to be expended in order to lose one $\mathrm{kg}$ of body fat). An impairment of fat oxidation is suggested as an important prerequisite to become obese (63). This may be the link with the observed correlations between calcium intake and obesity in the epidemiological studies. 
Nonetheless, data from two interventional studies indicate a possible role for calcium in body weight regulation. In one human intervention trial, an additive effect of increasing dietary calcium intake on weight loss was observed (51). But the end point of this experiment was body weight and not substrate metabolism. Furthermore, the subjects were obese and it has previously been shown that obese subjects show a larger increase in serum $1,25-\mathrm{OH}_{2} \mathrm{D}_{3}$ in response to a low-calcium diet (16). In another human intervention study, Melanson et al. observed a relation between acute $\mathrm{Ca} 2+$ intake and fat oxidation in normal weight subjects consuming an energy balanced diet. But the correlation between acute $\mathrm{Ca} 2+$ intake and fat oxidation was rather weak with $\mathrm{r} 2$ ranging from $0.32-0.38, \mathrm{p}=0.03-0.07$ (9), and food intake was not as well controlled as in the present randomized clinical trial. Furthermore, in the interventional study by Melanson and also some other previously published observational studies (3, 4, 9, 2426), an increased protein intake that is related to an increase in calcium intake may have confounded the outcome measures. So although these two intervention studies may point at an effect of calcium intake on energy and substrate metabolism, differences in methods and subjects make it difficult to compare them to the present study.

An alternative mechanism that may be responsible for the observed epidemiological relation between dairy and calcium intake and body weight is a reduced fat absorption from the gut induced by an increased calcium intake. In a very recent investigation Jacobsen et al. observed that increasing the dietary calcium intake from 675 to 1850 $\mathrm{mg} /$ day induced no differences in energy or substrate metabolism but a rather large increase of the faecal fat excretion of $8.2 \mathrm{~g}$ per day (from 6.0 to $14.2 \mathrm{~g}$ per day) (61). Papakonstantinou also showed in rats that increasing the dietary calcium intake decreased the energy that was available from the diet from 94 to $90 \%$ (64). Although the magnitude of these results is not in line with previous research showing more modest effects of dietary calcium on fat absorption $(65,66)$, it is clear that fat absorption may be an important mechanism by which calcium intake can influence body composition.

Summarizing the results from this investigation, we have shown that a 7-day dietary intervention with either a high or a low calcium diet induces significant changes in the serum $1,25-\mathrm{OH}_{2} \mathrm{D}_{3}$ concentration. However, these changes were not accompanied by differences in energy and substrate metabolism or alterations in the mRNA concentration of five genes involved in fat and substrate metabolism, which is in contrast with previous data. Possible explanations for this discrepancy are firstly that we have successfully corrected for the confounding effects of protein intake. Secondly, the power of the present investigation may be too small to detect differences in energy and substrate metabolism induced by different dietary calcium concentrations.

Finally, the results from other investigations $(61,65-67)$ also seem to indicate that the relation between dairy/calcium intake and body weight that has been observed in epidemiological reports may not be mediated by $1,25-\mathrm{OH}_{2} \mathrm{D}_{3}$, but by other mechanisms, for example the decreased fat absorption that is related to an increased calcium intake. This mechanism indeed warrants further investigation. 


\section{References}

1. Zemel MB. Nutritional and endocrine modulation of intracellular calcium: implications in obesity, insulin resistance and hypertension. Mol Cell Biochem 1998;188:129-36.

2. McCarron DA. Dietary calcium as an antihypertensive agent. Nutr Rev 1984;42:223-5.

3. Carruth BR, Skinner JD. The role of dietary calcium and other nutrients in moderating body fat in preschool children. Int J Obes Relat Metab Disord 2001;25:559-66.

4. Lin YC, Lyle RM, McCabe LD, McCabe GP, Weaver CM, Teegarden D. Dairy calcium is related to changes in body composition during a two-year exercise intervention in young women. J Am Coll Nutr 2000;19:754-60.

5. Heaney RP. Normalizing calcium intake: projected population effects for body weight. J Nutr 2003;133:268S-270S.

6. Teegarden D. Calcium intake and reduction in weight or fat mass. J Nutr 2003;133:249S-251S.

7. Barr SI. Increased dairy product or calcium intake: is body weight or composition affected in humans? J Nutr 2003;133:245S-248S.

8. Barr SI, McCarron DA, Heaney RP, et al. Effects of increased consumption of fluid milk on energy and nutrient intake, body weight, and cardiovascular risk factors in healthy older adults. J Am Diet Assoc 2000;100:810-7.

9. Melanson EL, Sharp TA, Schneider J, Donahoo WT, Grunwald GK, Hill JO. Relation between calcium intake and fat oxidation in adult humans. Int J Obes Relat Metab Disord 2003;27:196-203.

10. Zemel MB. Dietary calcium and dairy products accelerate weight and fat loss during energy restriction in obese adults. Nutr W Abstracts 2001:342-3s.

11. Zemel MB. Effects of calcium-fortified breakfast cereal on adiposity in a transgenic mouse model of obesity. Faseb J 2001:598 (abstr.).

12. Shi H, Dirienzo D, Zemel MB. Effects of dietary calcium on adipocyte lipid metabolism and body weight regulation in energy-restricted aP2-agouti transgenic mice. Faseb J 2001;15:291-3.

13. Zemel MB. Role of calcium and dairy products in energy partitioning and weight management. Am J Clin Nutr 2004;79:907S-12S.

14. Xue B, Moustaid N, Wilkison WO, Zemel MB. The agouti gene product inhibits lipolysis in human adipocytes via a Ca2+-dependent mechanism. Faseb J 1998;12:1391-6.

15. Sun X, Zemel MB. Calcium and Dairy Products Inhibit Weight and Fat Regain during Ad Libitum Consumption Following Energy Restriction in Ap2-Agouti Transgenic Mice. J Nutr 2004;134:3054-60.

16. Bell NH, Epstein S, Greene A, Shary J, Oexmann MJ, Shaw S. Evidence for alteration of the vitamin Dendocrine system in obese subjects. J Clin Invest 1985;76:370-3.

17. DeLuca HF, Zierold C. Mechanisms and functions of vitamin D. Nutr Rev 1998;56:S4-10; discussion S 54-75.

18. Barbe $\mathrm{P}$, Millet L, Larrouy D, et al. Uncoupling protein-2 messenger ribonucleic acid expression during very-low-calorie diet in obese premenopausal women. J Clin Endocrinol Metab 1998;83:2450-3.

19. Duque G, Macoritto M, Kremer R. 1,25(OH)2D3 inhibits bone marrow adipogenesis in senescence accelerated mice (SAM-P/6) by decreasing the expression of peroxisome proliferator-activated receptor gamma 2 (PPARgamma2). Exp Gerontol 2004;39:333-8.

20. Hida Y, Kawada T, Kayahashi S, Ishihara T, Fushiki T. Counteraction of retinoic acid and 1,25dihydroxyvitamin D3 on up-regulation of adipocyte differentiation with PPARgamma ligand, an antidiabetic thiazolidinedione, in 3T3-L1 cells. Life Sci 1998;62:PL205-11.

21. Large V, Arner P, Reynisdottir S, et al. Hormone-sensitive lipase expression and activity in relation to lipolysis in human fat cells. J Lipid Res 1998;39:1688-95.

22. Shi H, Norman AW, Okamura WH, Sen A, Zemel MB. 1alpha,25-Dihydroxyvitamin D3 modulates human adipocyte metabolism via nongenomic action. Faseb J 2001;15:2751-3.

23. Shi H, Norman AW, Okamura WH, Sen A, Zemel MB. 1alpha,25-dihydroxyvitamin D3 inhibits uncoupling protein 2 expression in human adipocytes. Faseb J 2002;16:1808-10.

24. Buchowski MS, Semenya J, Johnson AO. Dietary calcium intake in lactose maldigesting intolerant and tolerant African-American women. J Am Coll Nutr 2002;21:47-54.

25. Novotny R. Dairy, calcium and body composition of multiethnic youth. Asia Pac J Clin Nutr 2004; 13:S36 (abstr.).

26. Skinner JD, Bounds W, Carruth BR, Ziegler P. Longitudinal calcium intake is negatively related to children's body fat indexes. J Am Diet Assoc 2003;103:1626-31. 
27. Baba NH, Sawaya S, Torbay N, Habbal Z, Azar S, Hashim SA. High protein vs high carbohydrate hypoenergetic diet for the treatment of obese hyperinsulinemic subjects. Int J Obes Relat Metab Disord 1999;23:1202-6.

28. Eisenstein J, Roberts SB, Dallal G, Saltzman E. High-protein weight-loss diets: are they safe and do they work? A review of the experimental and epidemiologic data. Nutr Rev 2002;60:189-200.

29. Farnsworth E, Luscombe ND, Noakes M, Wittert G, Argyiou E, Clifton PM. Effect of a high-protein, energy-restricted diet on body composition, glycemic control, and lipid concentrations in overweight and obese hyperinsulinemic men and women. Am J Clin Nutr 2003;78:31-9.

30. Whitehead JM, McNeill G, Smith JS. The effect of protein intake on 24-h energy expenditure during energy restriction. Int J Obes Relat Metab Disord 1996;20:727-32.

31. Skov AR, Toubro S, Ronn B, Holm L, Astrup A. Randomized trial on protein vs carbohydrate in ad libitum fat reduced diet for the treatment of obesity. Int J Obes Relat Metab Disord 1999;23:528-36.

32. NEVO Tabel. Voorlichtingsbureau voor de voeding. Den Haag: Stichting Nederlands Voedingsstoffenbestand, 1996.

33. Siri WE. The gross composition of the body. Adv Biol Med Phys 1956;4:239-80.

34. Westerterp KR, Wouters L, van Marken Lichtenbelt WD. The Maastricht protocol for the measurement of body composition and energy expenditure with labeled water. Obes Res 1995;3 Suppl 1:49-57.

35. Harris. A biometric study of basal metabolism in man. Washington: Carnegie institution of Washington, 1919.

36. Schrauwen P. Determinants of energy and substrate metabolism. Maastricht: University of Maastricht, 1998.

37. Schrauwen P, van Marken Lichtenbelt WD, Saris WH, Westerterp KR. Changes in fat oxidation in response to a high-fat diet. Am J Clin Nutr 1997;66:276-82.

38. Hukshorn CJ, Saris WH, Westerterp-Plantenga MS, Farid AR, Smith FJ, Campfield LA. Weekly subcutaneous pegylated recombinant native human leptin (PEG-OB) administration in obese men. J Clin Endocrinol Metab 2000;85:4003-9.

39. Schoffelen PF, Westerterp KR, Saris WH, Ten Hoor F. A dual-respiration chamber system with automated calibration. J Appl Physiol 1997;83:2064-72.

40. Weir J. New methods for calculating metabolic rate with special reference to protein metabolism. Journal of Physiology 1949;109:101-9.

41. Brouwer E. On simple formulae for calculating the heat expenditure and the quantities of carbohydrate and fat oxidised in metabolism of men and animals, from gaseous exchange (oxygen uptake and carbonic acid output) and urine-n. Acta Physiol Pharmacol Neerlandica 1957;6:795-802.

42. Schrauwen P, van Marken Lichtenbelt WD, Saris WH, Westerterp KR. Role of glycogen-lowering exercise in the change of fat oxidation in response to a high-fat diet. Am J Physiol 1997;273:E623-9.

43. Basile JN, Liel Y, Shary J, Bell NH. Increased calcium intake does not suppress circulating 1,25dihydroxyvitamin D in normocalcemic patients with sarcoidosis. J Clin Invest 1993;91:1396-8.

44. Zemel MB, Shi H, Greer B, Dirienzo D, Zemel PC. Regulation of adiposity by dietary calcium. Faseb J 2000;14:1132-8.

45. Xue B, Greenberg AG, Kraemer FB, Zemel MB. Mechanism of intracellular calcium ([Ca2+]i) inhibition of lipolysis in human adipocytes. Faseb J 2001;15:2527-9.

46. Hamoui N, Anthone G, Crookes PF. Calcium metabolism in the morbidly obese. Obes Surg 2004;14:912.

47. Parikh SJ, Edelman M, Uwaifo GI, et al. The Relationship between Obesity and Serum 1,25-Dihydroxy Vitamin D Concentrations in Healthy Adults. J Clin Endocrinol Metab 2004;89:1196-9.

48. Melanson EL. The effects of low- and high-dairy diets on resting energy expenditure and substrate oxidation. Experimental Biology, 2004:A846.

49. Teegarden D. Calcium intake relates to change in body weight in young women. Faseb J 1999;13:A873-

50. Zemel MB. Role of dairy products in modulating weight and fat loss: A multi-center trial. Experimental Biology, 2004:A846.

51. Zemel MB, Richards J, Mathis S, Milstead A, Gebhardt L, Silva E. Dairy augmentation of total and central fat loss in obese subjects. Int J Obes Relat Metab Disord 2005.

52. Shi H, Halvorsen YD, Ellis PN, Wilkison WO, Zemel MB. Role of intracellular calcium in human adipocyte differentiation. Physiol Genomics 2000;3:75-82.

53. Xue B, Zemel MB. Relationship between human adipose tissue agouti and fatty acid synthase (FAS). J Nutr 2000;130:2478-81.

54. Davies KM, Heaney RP, Recker RR, et al. Calcium intake and body weight. J Clin Endocrinol Metab 2000;85:4635-8.

55. Gunther C. Lipid oxidation increases in women following a one year dairy calcium intervention. 2003. 
56. Jacqmain M, Doucet E, Despres JP, Bouchard C, Tremblay A. Calcium intake, body composition, and lipoprotein-lipid concentrations in adults. Am J Clin Nutr 2003;77:1448-52.

57. Kamycheva E, Joakimsen RM, Jorde R. Intakes of calcium and vitamin d predict body mass index in the population of Northern Norway. J Nutr 2003;133:102-6.

58. Lelovics Z. Relation between calcium and magnesium intake and obesity. Asia Pac J Clin Nutr 2004;13:S144 (abstr.).

59. Loos RJ, Rankinen T, Leon AS, et al. Calcium Intake Is Associated with Adiposity in Black and White Men and White Women of the HERITAGE Family Study. J Nutr 2004;134:1772-1778.

60. Pereira MA, Jacobs DR, Jr., Van Horn L, Slattery ML, Kartashov AI, Ludwig DS. Dairy consumption, obesity, and the insulin resistance syndrome in young adults: the CARDIA Study. Jama 2002;287:20819.

61. Jacobsen R, Lorenzen JK, Toubro S, Krog-Mikkelsen I, Astrup A. Effect of short-term high dietary calcium intake on 24-h energy expenditure, fat oxidation, and faecal fat excretion. Int J Obes Relat Metab Disord 2005;29:292-301.

62. Shapses SA, Heshka S, Heymsfield SB. Effect of calcium supplementation on weight and fat loss in women. J Clin Endocrinol Metab 2004;89:632-7.

63. Blaak EE, Saris WH. Substrate oxidation, obesity and exercise training. Best Pract Res Clin Endocrinol Metab 2002;16:667-78.

64. Papakonstantinou E, Flatt WP, Huth PJ, Harris RB. High dietary calcium reduces body fat content, digestibility of fat, and serum vitamin D in rats. Obes Res 2003;11:387-94.

65. Govers MJ, Termont DS, Lapre JA, Kleibeuker JH, Vonk RJ, Van der Meer R. Calcium in milk products precipitates intestinal fatty acids and secondary bile acids and thus inhibits colonic cytotoxicity in humans. Cancer Res 1996;56:3270-5.

66. Welberg JW, Monkelbaan JF, de Vries EG, et al. Effects of supplemental dietary calcium on quantitative and qualitative faecal fat excretion in man. Ann Nutr Metab 1994;38:185-91.

67. Shahkhalili Y, Murset C, Meirim I, et al. Calcium supplementation of chocolate: effect on cocoa butter digestibility and blood lipids in humans. Am J Clin Nutr 2001;73:246-52. 


\section{The effects of increasing serum calcitriol on energy and fat metabolism}

Niels Boon ${ }^{1}$, Gabby B.J. Hul ${ }^{1}$, Audrey Sicard ${ }^{2,}{ }^{3}$, Eveline Kole ${ }^{1}$, Elisa R. Van Den Berg $^{1}$, Nathalie Viguerie ${ }^{2,3}$, Dominique Langin ${ }^{2,3,4}$, Wim H.M. Saris ${ }^{1}$

${ }^{1}$ Nutrition and Toxicology Research Institute Maastricht, University of Maastricht, Maastricht, The Netherlands

${ }^{2,3}$ Inserm, U586, Unité de Recherches sur les Obésités, Toulouse, France

${ }^{2,3}$ Université Paul Sabatier, Institut Louis Bugnard

IFR31, Toulouse, France

${ }^{2,3,4} \mathrm{CHU}$ de Toulouse, Laboratoire de Biochimie,

Institut Fédératif de Biologie de Purpan, Toulouse, France

Obes Res 2006;14:1739-46. 


\begin{abstract}
Context: Evidence from both a number of investigations indicates that calcium intake could be inversely related to body weight, through alterations in the $1,25-\mathrm{OH}_{2}-\mathrm{D}_{3}$ metabolism.

Objective: To test if energy and substrate metabolism and adipose tissue enzyme mRNA expression can be altered by changes in serum $1,25-\mathrm{OH}_{2}-\mathrm{D}_{3}$ through oral cholecalciferol supplementation in non-obese human subjects.

Design: An intervention study was used, with a treatment period of 7 days. During this intervention, energy expenditure and substrate metabolism were measured using indirect calorimetry at $\mathrm{t}=0,1,3$, and 7 days, blood samples were obtained at $\mathrm{t}=-1,0,1,2,3,5$ and 7 days. Fat biopsies were obtained at $\mathrm{t}=0$ and 7 days for determination of expression of genes involved in lipolytic and lipogenic pathways.

Setting: Subjects from the general community studied ambulatory at a university hospital. Participants: Ten healthy young men (age: $28 \pm 3(\mathrm{y})$, body mass index (BMI) $\left.25.5 \pm 0.5\left(\mathrm{~kg} / \mathrm{m}^{2}\right)\right)$ were recruited by local announcement, and all completed the study. Intervention: All subjects received 2000 I.U. of cholecalciferol per day for 7 days and they were instructed to consume a low-cholecalciferol, low-calcium diet.

Main outcome measures: Energy expenditure, fat oxidation and adipose tissue enzyme mRNA were the main outcome measures.

Results: Despite a significant increase in serum $1,25-\mathrm{OH}_{2}-\mathrm{D}_{3}$ concentration at $\mathrm{t}=5$ and 7 days, no significant differences in substrate and energy metabolism, nor mRNA concentrations of different lipid-metabolism related proteins were observed.

58 Conclusion: 7-day supplementation with 2000 I.U. of cholecalciferol per day together with a decrease in dietary calcium intake does not affect EE or substrate metabolism, nor gene expression of proteins related to fat metabolism, despite a significant increase in serum $1,25-\mathrm{OH}_{2}-\mathrm{D}_{3}$ concentration.
\end{abstract}

Keywords: Dietary calcium, substrate metabolism, energy expenditure, serum 1,25$\mathrm{OH}_{2}-\mathrm{D}_{3}$, cholecalciferol supplementation. 


\section{Introduction}

Recently, in various epidemiological and clinical intervention trials, a relation between calcium intake and Body Mass Index (BMI) was observed in different populations (18 ). These effects of calcium intake on body weight regulation on the population level were confirmed in a clinical trial by Melanson et al., who observed a correlation between acute ( 24 hour) calcium intake and fat oxidation in human subjects on an isocaloric diet (9). Furthermore, possible beneficial effects of a high calcium intake have also been observed in a number of studies looking at the effects of dietary calcium intake during energy restriction. In these investigations, high calcium diets increased the loss of fat mass and increased energy expenditure compared to low calcium diets (1012).

Furthermore, in animal models and in cultures of human adipocytes it was shown that $1,25-\mathrm{OH}_{2}-\mathrm{D}_{3}$ causes acute increases in the intracellular calcium concentration $\left(\left[\mathrm{Ca}^{2+}\right]_{\mathrm{i}}\right)$ $(10,13)$. The increased $\left[\mathrm{Ca}^{2+}\right]_{\mathrm{i}}$ in the adipocytes activated lipogenesis and inhibited lipolysis. The serum concentration of $1,25-\mathrm{OH}_{2}-\mathrm{D}_{3}$ changes after a few days of an altered calcium intake (14). This way, decreasing the dietary calcium intake could increase body weight by inhibiting lipolysis and increasing lipogenesis, via an increase in serum $1,25-\mathrm{OH}_{2}-\mathrm{D}_{3}(1)$. Furthermore, $1,25-\mathrm{OH}_{2}-\mathrm{D}_{3}$ has been shown to cause a decrease in the mRNA expression of adipose tissue $U C P_{2}(15)$, a protein which mRNA expression is correlated with the basal metabolic rate in obese women (16). Changes in the expression of a number of other genes (i.e. peroxisome proliferator activated receptor gamma $(P P A R \gamma)$, fatty acid synthase $(F A S)$, glycerol phosphate dehydrogenase $\left(G P D H_{2}\right)$ and hormone sensitive lipase $\left.(H S L)\right)$ have also been observed in experiments studying the effects of calcium and $1,25-\mathrm{OH}_{2}-\mathrm{D}_{3}$ on adipocyte metabolism. The expression of these genes was shown to be affected by $1,25-\mathrm{OH}_{2}-\mathrm{D}_{3}$ (for $G P D H_{2}$ and $F A S$, see ref $(10)$, for $P P A R \gamma$, see refs $(17,18))$ or by alterations of the lipolytic activity (for $H S L$, see also ref (19)).

Based on these studies, a relation between calcium, 1,25- $-\mathrm{OH}_{2}-\mathrm{D}_{3}$ and energy/fat metabolism seems to exist, but clear evidence for the relevance of this relation in humans that are in energy balance has not been provided yet, because the investigations published so far were performed in humans or rodents consuming hypocaloric diets, which may have induced differences in substrate and energy metabolism. Furthermore, in most of the epidemiological and interventional research studies performed in humans mentioned here, the investigators have not corrected for the confounding effects of protein intake $(3,4,9,20-22)$. Since increasing the dietary calcium intake will most likely be achieved by increasing the dairy intake, this will lead to an increased protein intake. This macronutrient has been shown to have a weight lowering effect (23-27).

Therefore, we have previously tested the impact of altering the dietary calcium intake on energy and substrate metabolism in healthy subjects consuming an isocaloric diet, correcting for the confounding effects of protein intake. We showed that a 7-day high calcium/high dairy diet induced significant changes in the serum $1,25-\mathrm{OH}_{2}-\mathrm{D}_{3}$ concentration when compared to a low calcium/low dairy diet, but this did not lead to alterations of the energy and substrate metabolism (28). Furthermore, in two recent cross-sectional investigations, either an inverse relation (29) or no relation (30) was observed between serum $1,25-\mathrm{OH}_{2}-\mathrm{D}_{3}$ and $\mathrm{BMI}$ in obese humans that were in energy balance. These findings are not in line with the hypothesis that an increased calcium intake can decrease body weight through a decreased serum $1,25-\mathrm{OH}_{2}-\mathrm{D}_{3}$ concentration. 
In the context of these confusing data, we wanted to test the effects of a direct modulation of serum $1,25-\mathrm{OH}_{2}-\mathrm{D}_{3}$ levels, so the present investigation was carried out to test the hypothesis that a 7-day supplementation with 2000 I.U. of cholecalciferol per day together with a reduced dietary calcium intake induces alterations in substrate and energy metabolism through an increase in the serum $1,25-\mathrm{OH}_{2}-\mathrm{D}_{3}$ concentration. Fat biopsies were obtained to investigate if the possible changes in fat and energy metabolism are paralleled by changes in the expression of mRNA of different genes that are related to fat and energy metabolism.

\section{Experimental subjects}

Ten healthy subjects, age $28 \pm 3 \mathrm{y}$, height $1.74 \pm 0.02 \mathrm{~m}$, weight $77.1 \pm 2.3 \mathrm{~kg}$ and BMI $25.5 \pm 0.5 \mathrm{~kg} / \mathrm{m}^{2}$ participated in this study. All values are mean \pm SEM. This study was approved by the local ethical committee and after the subjects had received a written and oral explanation of the procedures to be followed in this project, their informed consent was obtained.

Table 1: Energy intake (MJ/day) and macronutrient composition, calcium (mg/day), dietary fiber ( $\mathrm{g} /$ day) and $1,25-\mathrm{OH}_{2} \mathrm{D}_{3}(\mu \mathrm{g} /$ day $)$ content of habitual and experimental diets $(\mathrm{n}=10)$

\begin{tabular}{lcc}
\hline \multicolumn{2}{c}{ Diet } \\
\hline & Habitual & Supplementation \\
Energy intake & $9.9 \pm 0.7$ & $9.0 \pm 0.8$ \\
E\%PRO & $15.6 \pm 0.9$ & $14.8 \pm 1.0$ \\
E\%CHO & $49.1 \pm 2.3$ & $50.0 \pm 2.0$ \\
E\%FAT & $31.1 \pm 1.3$ & $30.6 \pm 1.2$ \\
E\%ALC & $4.3 \pm 1.3$ & $3.2 \pm 1.1$ \\
calcium & $749 \pm 76$ & $352 \pm 31 \#$ \\
$1,25-\mathrm{OH}_{2} \mathrm{D}_{3}$ & $2.9 \pm 0.7$ & $1.6 \pm 0.3$ \\
Dietary fiber & $22.7 \pm 1.7$ & $22.6 \pm 1.8$ \\
\hline
\end{tabular}

All values are mean \pm SEM; \#Significantly different from experimental diets $(P<0.001)$; None of the other differences were statistically significant.

\section{Materials and methods}

To investigate the effects of the plasma $1,25-\mathrm{OH}_{2}-\mathrm{D}_{3}$ concentration on energy and substrate metabolism, subjects were studied during an 8-day period.

In order to determine the basal $1,25-\mathrm{OH}_{2}-\mathrm{D}_{3}$ concentration, blood samples were drawn at $\mathrm{t}=-1$ and 0 days. Consequently, subjects received an oral cholecalciferol supplement (2000 I.U./day) for 7 days. This amount of cholecalciferol has previously been shown to induce significant differences in serum $1,25-\mathrm{OH}_{2}-\mathrm{D}_{3}$ concentrations (31). On the morning of days $0,1,3$ and 7 , resting metabolic rate and fat oxidation were measured in the fasted state using indirect calorimetry. On day 1, 2, 3, 5 and 7 blood samples were drawn in the fasted state. On days 0 and 7, fat biopsies were obtained. 


\section{Cholecalciferol supplementation and dietary regimen}

Using 3-day food intake diaries, before the start of the experiment, assessed the habitual energy-, micro- and macronutrient intake of the subjects. During the 7-day period when the subjects consumed the cholecalciferol supplements, they were instructed to avoid consumption of calcium- and cholecalciferol-rich food items in order to standardize the intake of these micronutrients possibly affecting the serum calcitriol concentration. If the food diaries revealed that a subject habitually consumed certain foods rich in cholecalciferol or calcium, explicit instructions not to consume these items during the intervention were given. In order to increase adherence to this dietary regimen, subjects were given a list of different foods containing a high amount of either cholecalciferol or calcium and they kept a food intake diary throughout the experimental period. These food intake diaries were discussed upon every visit to the laboratory. Subjects were provided with a digital kitchen balance to allow them to make a more accurate estimation of their dietary intake.

The oral cholecalciferol supplements (Devaron 400 I.E. cholecalciferol) were ingested by the subjects on five separate occasions spread evenly over the course of the day, the time of ingestion of the supplements was to be registered. Empty packages of the supplements had to be returned upon every visit to the laboratory.

\section{Indirect calorimetry}

Subjects were instructed to report to the laboratory without performing any strenuous exercise after an overnight fast for the indirect calorimetry measurements. Using a ventilated-hood system (Omnical, Maastricht University, the Netherlands), measurements of $\mathrm{VO}_{2}$ and $\mathrm{VCO}_{2}$ were performed for $45 \mathrm{~min}$ at an environmental temperature of $22-24^{\circ} \mathrm{C}$ while subjects were semi-supine. To eliminate effects of subject habituation to the testing procedure, the respiratory measurements during the first $10 \mathrm{~min}$ were discarded. The last $15 \mathrm{~min}$ of the $45 \mathrm{~min}$ of measurement were excluded because the subjects became more restless at the end of the measurement. The ventilated hood measurements from 10 to 30 minutes were used to calculate resting metabolic rate (RMR). This protocol for determination of RMR has previously been validated (32)

Gas analyses were performed by dual paramagnetic $\mathrm{O}_{2}$ analyzers and dual infrared $\mathrm{CO}_{2}$ analyzers (type 1156, 1507, 1520; Servomex, Crowborough, Sussex, UK), similar to the analysis system described by Schoffelen et al. (33). Respiratory gas measurements were corrected for standard temperature, pressure and dry conditions. The Weir equation was used to convert $\mathrm{VO}_{2}$ and $\mathrm{VCO}_{2}$ values to energy expenditure (EE) values (34). Fat oxidation was also calculated from the indirect calorimetry values (35).

\section{Analytical methods}

After blood samples were drawn they were centrifuged at $4.000 \times \mathrm{g}$ for 10 minutes, aliquots of EDTA plasma and serum were frozen in liquid nitrogen and stored at $-80^{\circ} \mathrm{C}$ until further analysis.

Total plasma free fatty acids (FFA), glucose, free glycerol and serum calcium $\left(\mathrm{Ca}^{2+}\right)$ concentrations in the blood samples were measured using standard enzymatic techniques automated on Cobas MIRA and FARA centrifugal analysers at $340 \mathrm{~nm}$ (for FFA: FFA-C test kit, Wako Chemicals, Neuss, Germany; for glucose: Roche Unikit III, Hoffman-LaRoche Inc., Basel, Switzerland; for free glycerol: Roche Molecular Biochemicals, Mannheim, Germany, for $\mathrm{Ca}^{2+}$ : Calcium $\mathrm{CP}, \mathrm{ABX}$ pentra, Montpellier, 
France). 1,25- $-\mathrm{OH}_{2}-\mathrm{D}_{3}$ was determined using a monoclonal antibody RIA (ImmunoDiagnostic Systems Ltd., Boldon, United Kingdom).

After fat biopsies were obtained using a percutaneous needle attached to a vacuum syringe, blood and connective tissue were washed off with a sterile $0.9 \% \mathrm{NaCl}$ solution, consequently fat tissue was weighed and homogenized in $1 \mathrm{~mL}$ of a $1 \%$ solution of $\beta$ mercaptoethanol in RLT-buffer (RNeasy midi kit, Qiagen Inc) per $1000 \mathrm{mg}$ of fat tissue, frozen immediately in liquid nitrogen and stored at $-80^{\circ} \mathrm{C}$ until further analysis.

\section{Quantification of messenger RNAs in human adipose tissue biopsies using RT- qPCR}

Total RNA was extracted from adipose tissue biopsies using the RNeasy total RNA minikit (Qiagen, Courtaboeuf, France). First-strand cDNAs were first synthesized from $200 \mathrm{ng}$ total RNA in the presence of 100 units of Superscript II reverse transcriptase (Invitrogen, Cergy Pontoise, France) using random hexamer primers (Promega, Charbonnières, France). Real-time quantitative polymerase chain reactions (qPCR) were performed on a GeneAmp 7000 Sequence Detection System (Applied Biosystems, Foster City, CA, USA). Ten ng of cDNA were used as template for real-time PCR. The thermal cycler parameters for the real-time PCR were $2 \mathrm{~min}$ at $50^{\circ} \mathrm{C}$ followed by 40 cycles with $10 \mathrm{sec}$ at $95^{\circ} \mathrm{C}$ and $1 \mathrm{~min}$ at $60^{\circ} \mathrm{C}$. For each primer pair, a standard curve was obtained using serial dilutions of human adipose tissue cDNA prior to mRNA quantitation. For HSL a set of primers (Genset - Proligo France, Paris, France) was designed using the software Primer Express 1.5 (Applied Biosystems, Foster City, CA, USA) and used at a final concentration of $900 \mathrm{nM}$ with SYBR-Green based chemistry. A dissociation curve was generated at the end of the PCR cycles to verify that a single gene product was amplified. For $U C P_{2}, F A S, G P D H_{2}$ and $P P A R \gamma$ the Taqman approach was used. Both primers and TaqMan ${ }^{\mathrm{TM}}$ probes were obtained from Applied Biosystems (Foster City, CA, USA). The probes were labelled with a reporter dye (FAM) on the 5' end. The probe for $18 \mathrm{~S}$ ribosomal RNA was labelled with the reporter dyes $\mathrm{VIC}^{\mathrm{TM}}$ and TAMRA on the 5' end and the 3 ' end, respectively. For Taqman assays, because of very high specificity of the method, check for non-specific product formation with dissociation curve is not needed. We used 18S rRNA as control to normalize gene expression using the Ribosomal RNA Control TaqMan ${ }^{\mathrm{TM}}$ Assay kit (Applied Biosystems, Foster City, CA, USA). All reactions were performed in duplicate.

\section{Statistical analysis}

Possible significant differences induced by the cholecalciferol supplementation were calculated by using an ANCOVA analysis for repeated measures with the baseline measurements included as a covariate. The differences in blood parameters were calculated by comparing these values at the different time points to the average of the two baseline measurements $(\mathrm{t}=-1$ and $\mathrm{t}=0)$. These baseline values were included in the ANCOVA as outcome values and as covariate. Comparisons were performed using post hoc analyses. Possible differences between the habitual diets and the diets during the supplementation and possible differences in gene expression were tested with a paired samples t-test. A priori power calculations based upon differences in serum $1,25-\mathrm{OH}_{2} \mathrm{D}_{3}$ that we observed in a previous study looking at the effects of dietary calcium intake on energy metabolism and gene expression (28), indicated that a minimum of 10 subjects was required in order to attain a statistical power of $1-\beta=0.90$, assuming a difference in serum $1,25-\mathrm{OH}_{2} \mathrm{D}_{3}$ of $80 \mathrm{pmol} / \mathrm{l}$ and a standard deviation of $50 \mathrm{pmol} / \mathrm{l}$. Statistical 
difference was set at $\mathrm{p}<0.05$. SPSS for Mac version 11.0 (Chicago, IL) was used for the statistical analysis.

\section{Results}

\section{Diets}

The subjects' habitual diet contained 15.6 \pm 0.9 energy percent (E\%) as protein (PRO), $49.1 \pm 2.3 \mathrm{E} \%$ carbohydrate $(\mathrm{CHO}), 31.1 \pm 1.3 \mathrm{E} \%$ fat and $4.3 \pm 1.3 \mathrm{E} \%$ alcohol (ALC). The habitual energy intake (EI) of the subjects was $9.9 \pm 0.7 \mathrm{MJ} /$ day. During the supplementation, the diets of the subjects contained 14.8 $\pm 1.0 \mathrm{E} \% \mathrm{PRO}, 50.0 \pm 2.0 \mathrm{E} \%$ $\mathrm{CHO}, 30.6 \pm 1.2 \mathrm{E} \%$ fat and 3.2 $\pm 1.1 \mathrm{E} \%$ ALC. During supplementation, the EI of the subjects was $9.0 \pm 0.8 \mathrm{MJ} /$ day. These differences were not statistically significant. The habitual calcium and cholecalciferol intakes were $749 \pm 76 \mathrm{mg}$ per day and $2.9 \pm 0.7 \mu \mathrm{g}$ per day. These values declined to $352 \pm 31 \mathrm{mg}$ per day $(\mathrm{p}<0.001)$ and $1.6 \pm 0.3 \mu \mathrm{g}$ per day $(\mathrm{p}=0.1)$, respectively during the supplementation period (table 1$)$.

\section{Indirect calorimetry}

The relative contribution of fat oxidation to the resting energy expenditure was $47 \pm 7$, $41 \pm 6,60 \pm 9$ and $43 \pm 8 \%$ at $\mathrm{t}=0,1,3$ and 7 days, respectively. (figure 1 )

RMR values were $7.8 \pm 0.2,7.8 \pm 0.2,7.7 \pm 0.2$ and $7.6 \pm 0.2 \mathrm{MJ} / 24 \mathrm{~h}$ at $\mathrm{t}=0,1,3$ and 7 days, respectively and 24 hour fat oxidation at these time points was $95 \pm 16,84 \pm 14,105 \pm 13$ and $84 \pm 16 \mathrm{~g} / 24$ hour. None of these differences were statistically significant. (figure 2)

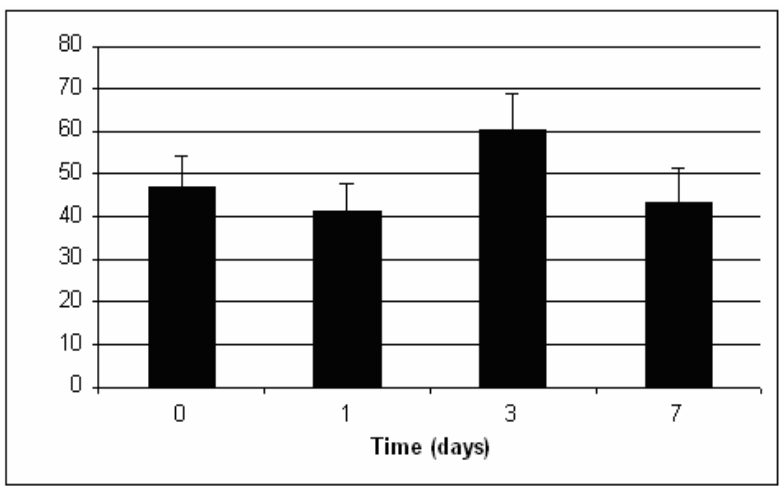

Figure 1: Contribution of fat oxidation to total resting metabolic rate $(\mathrm{MJ} /$ day $)$ as calculated from the indirect calorimetry measurements $(n=10)$. None of these differences were statistically significant.

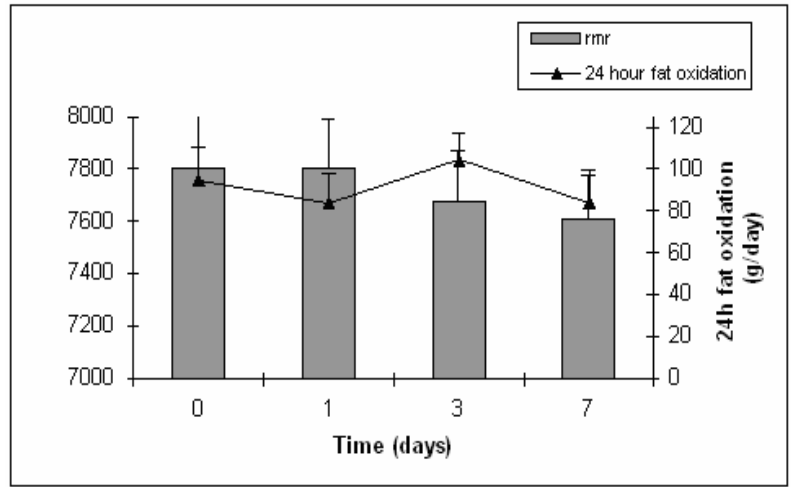

Figure 2: Resting metabolic rate (MJ/day) and 24-hour fat oxidation (g/day) $(\mathrm{n}=10)$. None of these differences were statistically significant. 


\section{Blood parameters}

The serum 1,25- $-\mathrm{OH}_{2}-\mathrm{D}_{3}$ concentration increased from $156 \pm 16 \mathrm{pmol} / \mathrm{l}$ (average of the time points $\mathrm{t}=-1$ and $\mathrm{t}=0$ days) to a maximum of $211 \pm 18 \mathrm{pmol} / 1$ on the third day of the cholecalciferol supplementation. At $\mathrm{t}=5$ and 7 days, the concentration was $202 \pm 14$ and $192 \pm 11 \mathrm{pmol} / 1$ and significantly different from baseline $(\mathrm{p}<0.05$ and $\mathrm{p}=0.01$, respectively). (figure 3 )

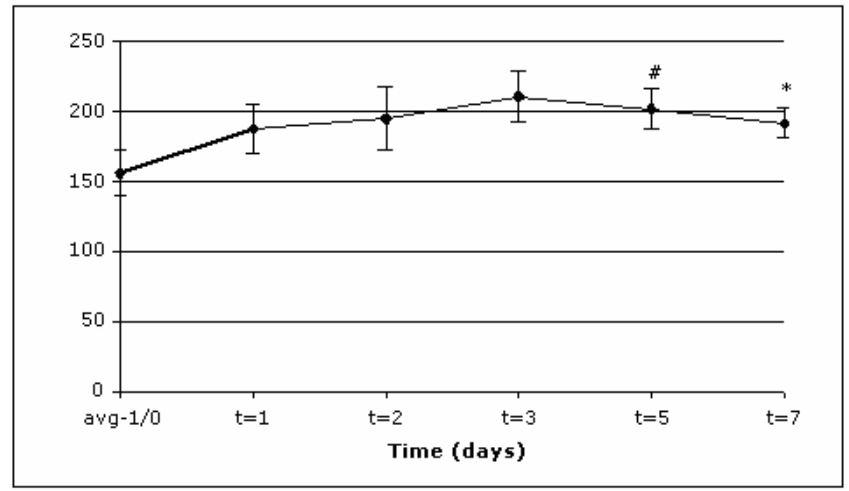

Figure 3: Serum 1,25- $-\mathrm{OH}_{2}-\mathrm{D}_{3}$ concentrations (pmol/1), $(\mathrm{n}=10)$. \#Denotes a significant difference when compared to the average of the two baseline measurements $(\mathrm{p}<0.05) *$ Denotes a significant difference when compared to the average of the two baseline measurements $(\mathrm{p}=0.010)$.

The glycerol concentration at $\mathrm{t}=3$ days was significantly different from baseline as well $(\mathrm{p}<0.05)$. No differences were observed in the other plasma values. All values were within the normal range (table 2).

Table 2: Plasma concentrations of glucose $(\mathrm{mmol} /)$, free fatty acids $(\mathrm{mmol} / \mathrm{l})$, glycerol $(\mu \mathrm{mol} / \mathrm{l})$ and serum concentrations of calcium $(\mathrm{mmol} / \mathrm{l})$ and $1,25-\mathrm{OH}_{2} \mathrm{D}_{3}(\mathrm{pmol} / \mathrm{l})$ during the 7-day supplementation with oral cholecalciferol

\begin{tabular}{lccccccc}
\hline $\begin{array}{l}\text { Time } \\
\text { (days) }\end{array}$ & AVG $-1 / 0$ & 1 & 2 & 3 & 5 & 7 & $\begin{array}{c}\text { Overall } \\
\text { p-value }\end{array}$ \\
\hline Glucose & $5.17 \pm 0.08$ & $5.18 \pm 0.09$ & $5.20 \pm 0.15$ & $5.18 \pm 0.14$ & $5.12 \pm 0.09$ & $5.09 \pm 0.14$ & 0.198 \\
FFA & $261 \pm 33$ & $268 \pm 45$ & $336 \pm 61$ & $267 \pm 40$ & $271 \pm 32$ & $288 \pm 62$ & 0.344 \\
Glycerol & $74 \pm 9$ & $61 \pm 9$ & $109 \pm 19$ & $67 \pm 10^{\#}$ & $85 \pm 9$ & $75 \pm 16$ & 0.026 \\
Calcium & $2.28 \pm 0.04$ & $2.27 \pm 0.05$ & $2.29 \pm 0.03$ & $2.25 \pm 0.03$ & $2.26 \pm 0.04$ & $2.25 \pm 0.03$ & 0.212 \\
$1,25-\mathrm{OH}_{2} \mathrm{D}_{3}$ & $156 \pm 16$ & $187 \pm 18$ & $195 \pm 22$ & $211 \pm 18$ & $202 \pm 14^{\#}$ & $192 \pm 11^{*}$ & 0.028 \\
\hline
\end{tabular}

AVG $-1 / 0$ is the average of the first two baseline measurements at $t=-1$ and $t=0$; All values are mean $\pm S E M$; "Denotes a significant difference when compared to the average of the two baseline measurements $(p<0.05)$; *Denotes a significant difference when compared to the average of the two baseline measurements $(p=0.010)$; None of the other differences were statistically significant. 


\section{mRNA expression}

The mRNA concentrations in adipose tissue were determined for 9 subjects only, because for 1 subject, no complete set of biopsies could be obtained due to his low body fat percentage. No statistically significant differences were observed in the mRNA

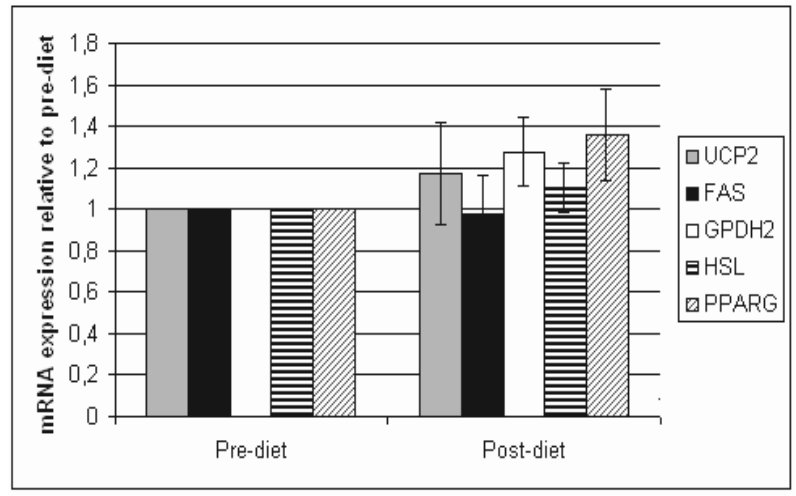

Figure 4: Adipose tissue $\mathrm{UCP}_{2}$, FAS, HSL, PPARG and $\mathrm{GPDH}_{2}$ mRNA expression., (n=9). None of these differences were statistically significant.

concentration of $\mathrm{UCP}_{2}, \mathrm{FAS}, \mathrm{GPDH}_{2}, \quad \mathrm{HSL}$ or PPAR $\gamma$ between the baseline measurement and the measurements at the end of the experimental period (figure 4).

\section{Discussion}

In this intervention study, we have investigated the effects of a 7-day oral supplementation with 2000 I.U. cholecalciferol per day on energy and substrate metabolism and adipose tissue gene expression of proteins related to energy and fat metabolism. Although the oral supplementation in combination with a low-calcium and low-cholecalciferol diet induced significant changes in the serum $1,25-\mathrm{OH}_{2}-\mathrm{D}_{3}$ concentrations, no differences in resting metabolic rate or fat oxidation were observed. The significant increase in serum glycerol concentration at $\mathrm{t}=3$ days could not be explained from the present data. We did not see any differences in gene expression of five genes involved in the lipogenic and lipolytic pathways, either. The magnitude of the increase in serum $1,25-\mathrm{OH}_{2}-\mathrm{D}_{3}$ we observed in this study was comparable to the increase in response to a low calcium diet $\left(349 \mathrm{mg} / \mathrm{d} \mathrm{Ca}^{2+}\right)$ in a previous investigation (28), which could also indicate that the change in serum $1,25-\mathrm{OH}_{2} \mathrm{D}_{3}$ is more a result of the differences in dietary calcium intake than of the supplementation with $1,25-\mathrm{OH}_{2} \mathrm{D}_{3}$. Along with the results from some other recent investigations in which no relation between $1,25-\mathrm{OH}_{2}-\mathrm{D}_{3}$ and body weight was observed (28-30), our results indicate that the $1,25-\mathrm{OH}_{2}-\mathrm{D}_{3}$ metabolism may not play a significant role in the relation of calcium with body weight.

Nonetheless, changes in the serum $1,25-\mathrm{OH}_{2}-\mathrm{D}_{3}$ concentration have been proposed as a possible mechanism behind the inverse relation of calcium intake and body weight that was observed in a number of observational studies $(1,3,4)$. But this hypothesis, which 
was based upon observations in cultured adipocytes may not be directly applicable to whole body human metabolism because the intracellular calcium concentrations in these experiments $(10,13,15,36-38)$ were manipulated directly by calcium channel and 1,25$\mathrm{OH}_{2}-\mathrm{D}_{3}$ receptor agonists and not through an altered dietary intake of calcium and therefore do not reflect the normal physiological situation.

However, beneficial effects of high-calcium diets on body weight loss were confirmed later by some studies using animal models and some human intervention studies (9-12). But because these studies were conducted in rodents or humans consuming hypo caloric diets, it is very hard to relate these results to the epidemiological data. Melanson et al. did show that the acute calcium intake is related to fat oxidation in weight stable humans. However, in this interventional study and also some other previously published observational studies $(3,4,9,20-22)$, an increased protein intake that is related to an increase in calcium intake may have confounded the outcome measures. Protein has previously been shown to be a macronutrient with several weight lowering effects, such as an increased thermogenesis and satiety compared to carbohydrates and fat (23-27).

An alternative mechanism that could be responsible for the observed epidemiological relation between dairy and calcium intake and body weight is a reduced fat absorption from the gut induced by an increased calcium intake. In a very recent investigation Jacobsen et al. observed that increasing the dietary calcium intake from 675 to 1850 $\mathrm{mg}$ /day induced no differences in energy or substrate metabolism but did cause a rather large increase of the faecal fat excretion of 8.2 gram per day (from 6.0 to 14.2 gram per day) (39). Papakonstantinou also showed in rats that increasing the dietary calcium intake decreased the energy that was available from the diet from 94 to $90 \%$ (40). Although the magnitude of these results is not in line with previous research showing more modest effects of dietary calcium on fat absorption $(41,42)$, fat absorption could be an important mechanism by which calcium intake can influence body composition.

A potential limitation of the present investigation is the absence of a placebo treatment. However, a placebo condition was not included in this study because the vitamin D treatment was used solely as a means to increase the serum $1,25-\mathrm{OH}_{2} \mathrm{D}_{3}$ concentration in order to test the hypothesis that a change in serum $1,25-\mathrm{OH}_{2} \mathrm{D}_{3}$ affects energy metabolism and gene expression. And although we observed the expected increase in serum vitamin $\mathrm{D}$ concentration, this was not paralleled by changes in gene expression or energy metabolism. There could also be a problem of statistical power to detect the differences induced by the oral $1,25-\mathrm{OH}_{2} \mathrm{D}_{3}$ supplementation. A post-hoc calculation revealed that with the observed differences and standard errors in fat oxidation (with a maximum of 20 gram per day between baseline and $t=3$ days), a minimum number of 94 subjects would have been needed to detect a significant effect of the oral supplementation on 24 hour fat oxidation.

Summarizing the results of the present investigation, the role of $1,25-\mathrm{OH}_{2}-\mathrm{D}_{3}$ in mediating a possible role between dairy and body weight regulation was investigated in more detail. We observed that the serum $1,25-\mathrm{OH}_{2}-\mathrm{D}_{3}$ concentration increased due to the oral supplementation and the decrease in dietary calcium intake and that the concentration of this hormone was significantly different from baseline after five and seven days of supplementation. These changes in the serum $1,25-\mathrm{OH}_{2}-\mathrm{D}_{3}$ concentration were not paralleled by differences in resting metabolic rate or fat oxidation or alterations in the mRNA concentration of five genes involved in fat and substrate metabolism.

Along with the results from some other recent investigations, it can be concluded from this intervention study that the relation between dairy/calcium intake and body weight 
that has been observed in epidemiological reports may not be mediated by $1,25-\mathrm{OH}_{2}-\mathrm{D}_{3}$, but by other mechanisms, for example an increased protein intake that is secondary to an increased calcium and dairy consumption or a decreased fat absorption. These mechanisms indeed warrant further investigation. 


\section{References}

1 Zemel MB. Nutritional and endocrine modulation of intracellular calcium: implications in obesity, insulin resistance and hypertension. Mol Cell Biochem 1998;188:129-36.

2 McCarron DA. Dietary calcium as an antihypertensive agent. Nutr Rev 1984;42:223-5.

3 Carruth BR, Skinner JD. The role of dietary calcium and other nutrients in moderating body fat in preschool children. Int J Obes Relat Metab Disord 2001;25:559-66.

4 Lin YC, Lyle RM, McCabe LD, McCabe GP, Weaver CM, Teegarden D. Dairy calcium is related to changes in body composition during a two-year exercise intervention in young women. $J$ Am Coll Nutr 2000;19:754-60.

5 Heaney RP. Normalizing calcium intake: projected population effects for body weight. $J$ Nutr 2003;133:268S-70S.

6 Teegarden D. Calcium intake and reduction in weight or fat mass. $J$ Nutr 2003;133:249S-51S.

7 Barr SI. Increased dairy product or calcium intake: is body weight or composition affected in humans? $J$ Nutr 2003;133:245S-8S.

8 Barr SI, McCarron DA, Heaney RP, et al. Effects of increased consumption of fluid milk on energy and nutrient intake, body weight, and cardiovascular risk factors in healthy older adults. J Am Diet Assoc 2000;100:810-7.

9 Melanson EL, Sharp TA, Schneider J, Donahoo WT, Grunwald GK, Hill JO. Relation between calcium intake and fat oxidation in adult humans. Int J Obes Relat Metab Disord 2003;27:196-203.

10 Shi H, Norman AW, Okamura WH, Sen A, Zemel MB. 1alpha,25-Dihydroxyvitamin D3 modulates human adipocyte metabolism via nongenomic action. Faseb J 2001;15:2751-3.

11 Zemel MB. Dietary calcium and dairy products accelerate weight and fat loss during energy restriction in obese adults. Nutr W Abstracts 2001:342-3s.

12 Zemel MB. Effects of calcium-fortified breakfast cereal on adiposity in a transgenic mouse model of obesity. Faseb J 2001:598 (abstr.).

13 Xue B, Moustaid N, Wilkison WO, Zemel MB. The agouti gene product inhibits lipolysis in human adipocytes via a Ca2+-dependent mechanism. Faseb $J$ 1998;12:1391-6.

14 Bell NH, Epstein S, Greene A, Shary J, Oexmann MJ, Shaw S. Evidence for alteration of the vitamin Dendocrine system in obese subjects. J Clin Invest 1985;76:370-3.

15 Shi H, Norman AW, Okamura WH, Sen A, Zemel MB. 1alpha,25-dihydroxyvitamin D3 inhibits uncoupling protein 2 expression in human adipocytes. Faseb $J$ 2002;16:1808-10.

16 Barbe P, Millet L, Larrouy D, et al. Uncoupling protein-2 messenger ribonucleic acid expression during very-low-calorie diet in obese premenopausal women. J Clin Endocrinol Metab 1998;83:2450-3.

17 Hida Y, Kawada T, Kayahashi S, Ishihara T, Fushiki T. Counteraction of retinoic acid and 1,25dihydroxyvitamin D3 on up-regulation of adipocyte differentiation with PPARgamma ligand, an antidiabetic thiazolidinedione, in 3T3-L1 cells. Life Sci 1998;62:PL205-11.

18 Duque G, Macoritto M, Kremer R. 1,25(OH)2D3 inhibits bone marrow adipogenesis in senescence accelerated mice (SAM-P/6) by decreasing the expression of peroxisome proliferator-activated receptor gamma 2 (PPARgamma2). Exp Gerontol 2004;39:333-8.

19 Large V, Arner P, Reynisdottir S, et al. Hormone-sensitive lipase expression and activity in relation to lipolysis in human fat cells. J Lipid Res 1998;39:1688-95.

20 Buchowski MS, Semenya J, Johnson AO. Dietary calcium intake in lactose maldigesting intolerant and tolerant African-American women. J Am Coll Nutr 2002;21:47-54.

21 Novotny R. Dairy, calcium and body composition of multiethnic youth. Asia Pac J Clin Nutr 2004;13:S36 (abstr.).

22 Skinner JD, Bounds W, Carruth BR, Ziegler P. Longitudinal calcium intake is negatively related to children's body fat indexes. J Am Diet Assoc 2003;103:1626-31.

23 Baba NH, Sawaya S, Torbay N, Habbal Z, Azar S, Hashim SA. High protein vs high carbohydrate hypoenergetic diet for the treatment of obese hyperinsulinemic subjects. Int J Obes Relat Metab Disord 1999;23:1202-6.

24 Eisenstein J, Roberts SB, Dallal G, Saltzman E. High-protein weight-loss diets: are they safe and do they work? A review of the experimental and epidemiologic data. Nutr Rev 2002;60:189-200.

25 Farnsworth E, Luscombe ND, Noakes M, Wittert G, Argyiou E, Clifton PM. Effect of a high-protein, energy-restricted diet on body composition, glycemic control, and lipid concentrations in overweight and obese hyperinsulinemic men and women. Am J Clin Nutr 2003;78:31-9.

26 Whitehead JM, McNeill G, Smith JS. The effect of protein intake on 24-h energy expenditure during energy restriction. Int J Obes Relat Metab Disord 1996;20:727-32. 
27 Skov AR, Toubro S, Ronn B, Holm L, Astrup A. Randomized trial on protein vs carbohydrate in ad libitum fat reduced diet for the treatment of obesity. Int J Obes Relat Metab Disord 1999;23:528-36.

28 Boon N, Hul GB, Viguerie N, Sicard A, Langin D, Saris WH. Effects of 3 diets with various calcium contents on 24-h energy expenditure, fat oxidation, and adipose tissue message RNA expression of lipid metabolism-related proteins. Am J Clin Nutr 2005;82:1244-52.

29 Parikh SJ, Edelman M, Uwaifo GI, et al. The Relationship between Obesity and Serum 1,25-Dihydroxy Vitamin D Concentrations in Healthy Adults. J Clin Endocrinol Metab 2004;89:1196-9.

30 Hamoui N, Anthone G, Crookes PF. Calcium metabolism in the morbidly obese. Obes Surg 2004;14:912.

31 Zittermann A. Vitamin D in preventive medicine: are we ignoring the evidence? Br J Nutr 2003;89:55272.

32 Adriaens MP, Schoffelen PF, Westerterp KR. Intra-individual variation of basal metabolic rate and the influence of daily habitual physical activity before testing. Br J Nutr 2003;90:419-23.

33 Schoffelen PF, Westerterp KR, Saris WH, Ten Hoor F. A dual-respiration chamber system with automated calibration. J Appl Physiol 1997;83:2064-72.

34 Weir J. New methods for calculating metabolic rate with special reference to protein metabolism. Journal of Physiology 1949;109:101-9.

35 Peronnet F, Massicotte D. Table of nonprotein respiratory quotient: an update. Can J Sport Sci 1991;16:23-9.

36 Shi H, Halvorsen YD, Ellis PN, Wilkison WO, Zemel MB. Role of intracellular calcium in human adipocyte differentiation. Physiol Genomics 2000;3:75-82.

37 Xue B, Greenberg AG, Kraemer FB, Zemel MB. Mechanism of intracellular calcium ([Ca2+]i) inhibition of lipolysis in human adipocytes. Faseb $J$ 2001;15:2527-9.

38 Xue B, Zemel MB. Relationship between human adipose tissue agouti and fatty acid synthase (FAS). $J$ Nutr 2000;130:2478-81.

39 Jacobsen R, Lorenzen JK, Toubro S, Krog-Mikkelsen I, Astrup A. Effect of short-term high dietary calcium intake on 24-h energy expenditure, fat oxidation, and faecal fat excretion. Int J Obes Relat Metab Disord 2005;29:292-301.

40 Papakonstantinou E, Flatt WP, Huth PJ, Harris RB. High dietary calcium reduces body fat content, digestibility of fat, and serum vitamin D in rats. Obes Res 2003;11:387-94.

41 Govers MJ, Termont DS, Lapre JA, Kleibeuker JH, Vonk RJ, Van der Meer R. Calcium in milk products precipitates intestinal fatty acids and secondary bile acids and thus inhibits colonic cytotoxicity in humans. Cancer Res 1996;56:3270-5.

42 Welberg JW, Monkelbaan JF, de Vries EG, et al. Effects of supplemental dietary calcium on quantitative and qualitative faecal fat excretion in man. Ann Nutr Metab 1994;38:185-91. 


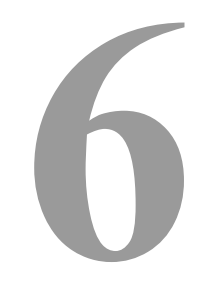

\section{The effects of hydralazine on lipolysis in subcutaneous adipose tissue in humans}

Niels Boon, Gijs H. Goossens, Ellen E. Blaak, Wim H.M. Saris

Nutrition and Toxicology Research Institute Maastricht, University of Maastricht, Maastricht, The Netherlands

Metabolism 2007: under review 


\begin{abstract}
Context: Recent evidence from animal research and in vitro experiments indicates that changes in dietary calcium intake could cause changes in lipolysis through alterations of the intracellular calcium concentration in adipocytes.

Objective: To examine whether the calcium antagonist hydralazine affects blood flow and lipolysis in subcutaneous abdominal adipose tissue in vivo in humans.

Design: Three different concentrations of hydralazine (12.2, 24.4 and $48.8 \mu \mathrm{M})$ were locally administered in adipose tissue using the microdialysis technique to assess effects on lipolysis and blood flow in subcutaneous adipose tissue in the abdominal region.

Setting: Subjects from the general community studied ambulatory at a university hospital. Participants: Eight healthy men (age: $33.1 \pm 3.3$ (y), body mass index (BMI) $\left.24.2 \pm 0.2\left(\mathrm{~kg} / \mathrm{m}^{2}\right)\right)$ were recruited by local announcement.

Intervention: Subcutaneous adipose tissue in the abdominal region was perfused with increasing concentrations of hydralazine.

Main outcome measures: Adipose tissue lipolysis and blood flow.

Results: Hydralazine had no effect on ethanol out/in-ratios, but significantly increased in interstitial glycerol concentration at the highest concentration $(p<0.05)$.

Conclusion: The present results indicate that hydralazine increases lipolysis in abdominal subcutaneous adipose tissue in healthy lean subjects, but hydralazine had no significant effects on local blood flow in adipose tissue.
\end{abstract}

Keywords: hydralazine, intracellular calcium, lipolysis, adipose tissue, microdialysis 


\section{Introduction}

The prevalence of obesity has increased markedly during the past two decades and it is an important risk factor for the development of type 2 diabetes, various types of cancer, and cardiovascular complications. In recent years, an inverse relation between dietary calcium and Body Mass Index (BMI) was repeatedly observed (1-8). Some intervention studies also show that dietary calcium may have weight-lowering effects (9-12).

A possible mechanism to explain this relation could be as follows (13); Decreasing the concentration of $1,25-\mathrm{OH}_{2} \mathrm{D}_{3}$ in cultures of human adipocytes and in transgenic mice caused acute decreases of the intracellular calcium concentration in adipocytes $(14,15)$. Interestingly, this reduction in intracellular calcium concentration could decrease lipogenesis through a $\mathrm{Ca}^{2+-}$ dependent inhibition of fatty acid synthase (FAS) expression and increase lipolysis through an inhibition of phosphodiesterase $3 \mathrm{~b}$ and an increase in the cAMP concentration. The latter increases the phosphorylation of hormone sensitive lipase thus increasing the rate of lipolysis $(1,16-18)$. In this way, a high dietary calcium intake may lead to a lower body weight by changing the rate of lipolysis and lipogenesis in adipose tissue through a decrease in serum $1,25-\mathrm{OH}_{2} \mathrm{D}_{3}(1)$.

In order to be able to study the in situ effects of modifying the intracellular calcium concentration in human adipocytes, we used hydralazine in the present microdialysis study. Hydralazine is a vasodilator clinically used to treat hypertension. Furthermore, it has previously been shown in microdialysis experiments to cause vasodilatation (19, 20). The effects of hydralazine on vasodilatation are mediated through antagonistic effects on the intracellular calcium concentration in smooth muscle tissue of blood vessels. Hydralazine has been shown to cause a reduction in the intracellular calcium concentration of rabbit vessels, via a decreased 1,4,5 myo-inositol phosphate (IP3) activity, which in turn caused a decrease in the release of calcium from the sarcoplasmatic reticulum (21). Furthermore, decreases in body weight in a rabbit model of obesity were also observed as a response to treatment with hydralazine (22). Moreover, in a previous investigation from our laboratory, lipolytic effects of hydralazine were observed in skeletal muscle tissue using the microdialysis technique (20). Based on these findings we hypothesized that changes in the intracellular calcium concentration induced by the calcium antagonist hydralazine could induce an increase in lipolysis in human adipose tissue.

In this investigation, we studied the effects on adipose tissue blood flow and lipolysis of local perfusion of subcutaneous adipose tissue in the abdominal region with three different concentrations of the calcium antagonist hydralazine. 


\section{Materials and methods}

\section{Subjects}

Eight healthy male subjects were studied in this investigation. All subjects were free from overt disease, not participating in any regular physical activity for $>3$ hours/week and the habitual macronutrient, total energy, calcium and fibre intake of the subjects was determined with a 3-day food intake questionnaire. The Ethical Committee of the Academic Hospital Maastricht and the University of Maastricht approved of the protocol, the nature and risks of the experimental procedures were explained to the subjects and their informed consent was obtained.

Table 1: Physical characteristics and habitual nutrient intake of the male subjects $(n=8)$

\begin{tabular}{lc}
\hline Age $(\mathrm{y})$ & $33 \pm 3$ \\
Height $(\mathrm{m})$ & $1.84 \pm 0.03$ \\
Weight $(\mathrm{kg})$ & $84.3 \pm 2.8$ \\
BMI $(\mathrm{kg} / \mathrm{m} 2)$ & $24.3 \pm 0.4$ \\
Body Fat $(\%)$ & $21.3 \pm 1.7$ \\
Energy (MJ) & $12.8 \pm 2.1$ \\
EN\%PRO & $15.8 \pm 0.4$ \\
EN\%CHO & $48.8 \pm 0.9$ \\
EN\%FAT & $33.9 \pm 1.6$ \\
Calcium (mg) & $1471 \pm 158$ \\
Fiber (g) & $23.0 \pm 4.4$ \\
\hline
\end{tabular}

All values are mean \pm SEM; BMI: Body Mass Index; EN\%PRO: Energy percentage as protein intake; EN\%CHO: Energy percentage as carbohydrate intake; EN\%FAT: Energy percentage as fat intake.

\section{Body composition and anthropometrical measurements}

Whole body density was determined by underwater weighing in the morning after an overnight fast. Body weight was measured with a digital balance with an accuracy of $0.01 \mathrm{~kg}$ (Sauter, type E1200) and height was measured to the nearest $0.01 \mathrm{~m}$. Lung volume was measured simultaneously with the helium dilution technique using a spirometer (Volugraph 2000, Mijnhardt).

\section{Microdialysis protocol}

Subjects were asked to report to the laboratory for the microdialysis trial in the morning after an overnight fast. They were asked not to consume any alcohol and not to perform heavy physical exercise during the 24 hours preceding the experiment. They were studied in the supine position on a hospital bed, while the ambient temperature was kept at $23-25^{\circ} \mathrm{C}$.

Consequently, two microdialysis probes (CMA-60, CMA microdialysis, Solna, Sweden) were inserted into the subcutaneous abdominal adipose tissue. The skin was anaesthetised locally with a lidocaine and prolocaine containing crème $(25 \mathrm{mg} / \mathrm{g})$ (Emla, 
Astra Pharmaceuticals, Zoetermeer, The Netherlands), which was applied one hour before the start of the experiment. Probes were placed $5-8 \mathrm{~cm}$ left and right from the umbilicus.

Probes consisted of dialysis tubing $\left(30 \mathrm{x} 0.6 \mathrm{~mm}^{2}, 20 \mathrm{kDa}\right.$ cut-off) glued to the end of a double lumen polyurethane canula. The perfusion solvent entered the probe through the inner canula, passed down to the tip of the probe, streamed upwards in the space between the inner canula and the outer dialysis membrane and left the probe through the outer canula via a side arm, from which the dialysate was collected.

After insertion, the catheters were flushed with Ringer perfusion fluid (the composition of this fluid was as follows: $\mathrm{Na}^{+} 147 \mathrm{mmol} / \mathrm{l}, \mathrm{K}^{+} 4 \mathrm{mmol} / \mathrm{l}, \mathrm{Ca}^{2+} 2.3 \mathrm{mmol} / \mathrm{l}, \mathrm{Cl}^{-} 156$ $\mathrm{mmol} / \mathrm{l}, \mathrm{pH}=6$ and an osmolality of $290 \mathrm{mosmol} / \mathrm{kg}$ ) to clear the microdialysis membranes from air bubbles. Thereafter, Ringer perfusion fluid supplemented with 50 $\mathrm{mM}$ ethanol was perfused at a flow rate of $0.5 \mu \mathrm{l} / \mathrm{min}$ for $90 \mathrm{~min}$ before the start of the experiment to allow for recovery of the adipose tissue at the site where the probes were inserted. Consequently, the real interstitial glycerol concentration was determined with the zero flow method (23). For this determination, dialysate was collected in two 20minute fractions at a flow rate of $0.5 \mu \mathrm{l} / \mathrm{min}$ and in three 10 -minute fractions at flow rates of $1.0,2.5$ and $5.0 \mu \mathrm{l} / \mathrm{min}$. The perfusion at $5.0 \mu \mathrm{l} / \mathrm{min}$ was used as a baseline measurement for the second part of the experiment. Dialysate glycerol concentrations were $\log$ transformed and plotted against perfusion rates. Linear regression analysis was used to calculate the glycerol concentration at the zero flow rate, corresponding to the real interstitial glycerol concentration. The in vivo recovery rate of the probe was calculated by dividing the dialysate glycerol concentration at $5.0 \mu \mathrm{l} / \mathrm{min}$ by the calculated interstitial glycerol concentration. Furthermore, the ethanol concentration was determined both in the ingoing and outgoing perfusion solvent to assess the ethanol outflow/inflow (out/in) ratio as indicator for local nutritive blood flow (ethanol dilution technique) $(24,25)$.

During the second part of the experiment, one probe was perfused with increasing concentrations of hydralazine; 12.2, 24.4 and 48.8 $\mu \mathrm{M}$ (Souvereign Medical, Basildon, United Kingdom) at a flow rate of $5.0 \mu \mathrm{l} / \mathrm{min}$. The other probe served as a control probe and was perfused with Ringer fluid at a flow rate of $5.0 \mu \mathrm{l} / \mathrm{min}$ throughout the experiment.

During each 60-minute hydralazine perfusion period, dialysate was collected in six 10min fractions. Each perfusion period was followed by a 30-minute washout, during which Ringer solution supplemented with $50 \mathrm{mM}$ ethanol was perfused. During these washout periods, dialysate was collected in 10-minute fractions as well.

The glycerol concentrations and ethanol ratios presented here are the averages of the last 3 fractions during the experimental periods and the averages of the last 2 fractions during the washout periods. 


\section{Analytical methods}

Glycerol and ethanol concentrations in the dialysate were determined on a Cobas Fara centrifugal analyser (Roche Diagnostica, Basel, Switzerland); glycerol concentrations were measured fluorimetrically using a standard glycerol kit (Boehringer, Mannheim, Germany), but with adapted concentrations of NADH, enzymes and buffer to achieve accurate fluorimetric detection and ethanol concentrations were measured spectrophotometrically at $340 \mathrm{~nm}$ using a standard ethanol assay kit (176290, Boehringer, Mannheim, Germany).

\section{Statistical analysis}

To compare the effects of the different concentrations of hydralazine, a repeated measures ANOVA was performed and a Scheffé test was used for post-hoc analysis. A paired samples T-test was used to test for differences between the experimental and control probes. SPSS 11.0.4 for Mac OS X (Chicago, IL, USA) was used for statistical analysis. All values are means \pm SEM. Statistical difference was set at $\mathrm{p}<0.05$.

\section{Results}

\section{Subject characteristics}

The subjects had an average age (y.) and BMI (Body Mass Index, kg/m2) of 33.1 \pm 3.3 and $24.2 \pm 0.2$, respectively. The average body fat $\%$ of our subjects was $21.3 \pm 1.7$ as determined with the hydrodensitometry measurements. (Table 1) In general, the habitual nutrient intake was within a normal range for this age and sex group. However, the habitual calcium intake was around $200 \mathrm{mg}$ /day higher than the average for this age and sex group (26).

\section{Ethanol out/in ratio}

The baseline ethanol out/in ratio was $0.80 \pm 0.04$ in the experimental probe and $0.86 \pm 0.05$ in the control probe. $(\mathrm{p}=0.18)$. These values decreased to $0.68 \pm 0.05$ and $0.78 \pm 0.06$ at the end of the experiment (i.e. after perfusion with the highest concentration of hydralazine) in the experimental and control probes, respectively. These values were significantly different from baseline $(p=0.001$ for the experimental and $\mathrm{p}<0.05$ for the control probe) The ethanol delta, calculated by subtracting the concentration of ethanol in the control probe from the concentration in the experimental probe at corresponding time points, did not change significantly throughout the experiment. (Figures $1 \mathrm{a}$ and $1 \mathrm{~b}$ )

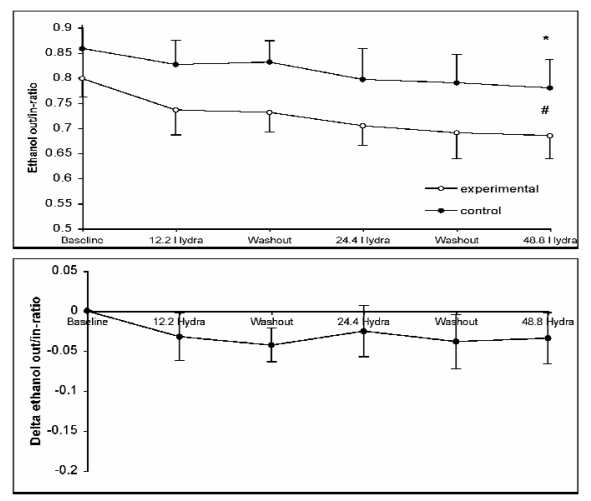

Figure 1: Effects of hydralazine on the ethanol out/in ratios in abdominal subcutaneous tissue $(\mathrm{N}=8)$. Data in bottom figure are adjusted for corresponding changes in the control probes and presented as changes from baseline. *, $\mathrm{P}<0.05$ compared to baseline. \#, $\mathrm{P}=0.001$ compared to baseline. 


\section{Interstitial glycerol concentration}

The baseline interstitial glycerol concentration was $218 \pm 34 \mu \mathrm{mol} / 1$ in the experimental probe and $207 \pm 29 \mu \mathrm{mol} / 1$ in the control probe. This difference was not statistically significant $(\mathrm{p}=0.715)$. These values decreased to $204 \pm 30$ and $140 \pm 30 \mu \mathrm{mol} / 1$ at the end of the experiment in the experimental and control probes, respectively. This decrease was significantly different from baseline in the control condition $(p<0.01)$. The glycerol delta, calculated by subtracting the concentration of glycerol in the control probe from the concentration in the experimental probe at corresponding time points, was $63 \pm 27$ $\mu \mathrm{mol} / \mathrm{l}$ at the end of the experiment ( $\mathrm{p}=0.05$, compared to baseline). (Figures $2 \mathrm{a}$ and $2 \mathrm{~b}$ )
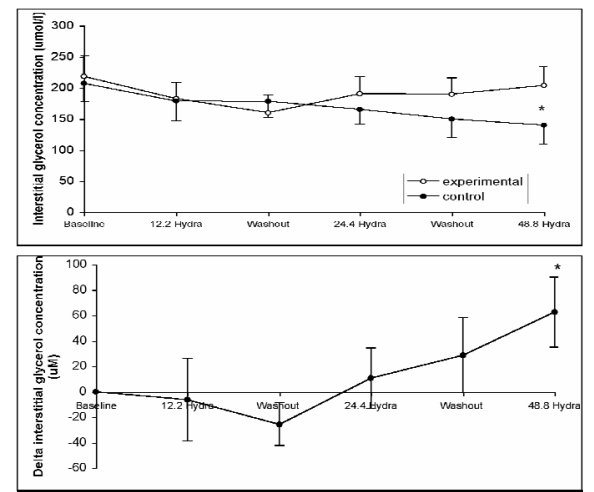

Figure 2: Effects of hydralazine on the interstitial glycerol concentration in abdominal subcutaneous tissue, $(\mathrm{N}=8)$. Data in bottom figure are adjusted for corresponding changes in the control probes and presented as changes from baseline. ${ }^{*}, \mathrm{P}<0.01$ compared to baseline \#, $\mathrm{P}<0.05$ compared to baseline.

\section{Discussion}

We observed that perfusing the abdominal subcutaneous adipose tissue of healthy men with hydralazine increased the interstitial glycerol concentration despite a nonsignificant increase in blood flow in the experimental probe. This could indicate a lipolytic effect of hydralazine, which was only observed at the highest concentration of $48.8 \mu \mathrm{M}$.

Although modest increases in blood flow in the control condition have been observed previously in microdialysis experiments (20), the increase we observed here is larger. The subjects in this investigation were relatively lean and young and it could be possible that they were more sensitive to changes in blood flow due to the long fasting period. However, the increase in blood flow was slightly more pronounced in the experimental condition, although this was not significant.

In previous investigations from our laboratory, we have looked at possible effects of calcium intake on body weight because a possible obesity-inducing effect of a decreased dietary calcium intake was proposed by Zemel et al. (13). They observed acute increases of the intracellular calcium concentration in adipocytes when they increased the concentration of $1,25-\mathrm{OH}_{2} \mathrm{D}_{3}$ in cultures of human adipocytes and in an agouti transgenic mouse model $(14,15)$. This increased level of $\mathrm{Ca}^{2+}$ in the adipocytes lowered lipolysis. Lowering dietary calcium intake leads to an increase in the serum concentration of $1,25-\mathrm{OH}_{2} \mathrm{D}_{3}$ within a few days (27). Putting these observations together, a low dietary calcium intake may lead to a higher body weight by changing the rate of lipolysis and lipogenesis in adipose tissue through an increase in serum 1,25- 
$\mathrm{OH}_{2} \mathrm{D}_{3}$ and a consequent increase in intracellular calcium in adipocytes (1). In a number of intervention studies, it was indeed observed that a high dietary calcium intake leads to larger decreases in body fat and a smaller decrease of lean body mass during energy restriction in both humans and rodents $(10,11,13,28-31)$, but data are still controversial (32-37) in both humans and rodents. Furthermore, recent evidence from this laboratory also does not support the hypothesis mentioned above $(38,39)$. In these experiments, although we did observe that an increase in dietary calcium intake or an oral supplementation with $1,25-\mathrm{OH}_{2} \mathrm{D}_{3}$ increased serum $1,25-\mathrm{OH}_{2} \mathrm{D}_{3}$, no effects on fat and energy metabolism or on mRNA expression in adipose tissue of various genes involved in fat metabolism were found $(38,39)$, so we wanted to test the last part of the hypothesis (i.e. lowering intracellular calcium increases lipolysis) in more detail.

Interestingly, Goossens et al. observed a lipolytic effect of hydralazine on skeletal muscle tissue (20). Their data suggested that hydralazine might also exert lipolytic effects on adipose tissue, since the antilipolytic effects of angiotensin II were completely abolished when co-infused with hydralazine. A possible mechanism to explain the effects observed in this investigation is that hydralazine increases lipolysis by decreasing intracellular calcium in adipocytes. Hydralazine was shown to decrease the activity of IP3 in rabbit aorta and pulmonary artery (21). A decreased activity of IP3 has been shown to reduce the calcium release from isolated rat adipocyte endoplasmatic reticulum. As mentioned above, decreases in intracellular calcium have been shown to increase lipolysis (16). Taken together, hydralazine could increase lipolysis in adipose tissue via a decrease in intracellular calcium through a decreased activity of IP3. Furthermore, it has been observed in rat adipocytes that angiotensin II increases intracellular calcium in rat adipocytes (40), which fits in with the findings from Goossens et al. as they observed anti-lipolytic effects of the calcium agonist angiotensin II in adipose tissue. This could point to a possible role for the intracellular calcium concentration in regulating lipolysis in human adipose tissue. But because in none of these experiments in which lipolytic effects of hydralazine were observed, measurements of intracellular calcium were done, it remains unclear if these effects of hydralazine are directly mediated by intracellular calcium or by other mechanisms.

Data from this experiment may lead to a better understanding of the relevance of the hypothesis postulated by Zemel et al. $(13-15,18)$. We have previously shown that the first step of this hypothesis (i.e. increasing dietary calcium intake decreases serum 1,25$\left.\mathrm{OH}_{2} \mathrm{D}_{3}\right)$ is present in humans $(38,39)$ and in the present investigation, we have obtained indirect evidence that the last step (i.e. decreasing intracellular calcium in adipocytes increases lipolysis) could also be valid in humans. However, because we observed no effects on whole body level of increasing dietary calcium on energy expenditure or fat metabolism, it could be postulated that the second step (i.e. changes in serum 1,25$\mathrm{OH}_{2} \mathrm{D}_{3}$ induce changes in intracellular calcium) is not valid in humans.

In conclusion, we have observed that perfusing adipose tissue of healthy subjects with hydralazine increased lipolysis in abdominal adipose tissue in healthy lean subjects. This effect may be mediated by alterations of the intracellular calcium concentration in adipocytes, but the present data do not provide direct evidence for this mechanism. Therefore, this mechanism warrants further investigations using an experimental setup that allows for a direct measurement of intracellular calcium. 


\section{References}

1. Zemel MB. Nutritional and endocrine modulation of intracellular calcium: implications in obesity, insulin resistance and hypertension. Mol Cell Biochem 1998;188:129-36.

2. McCarron DA. Dietary calcium as an antihypertensive agent. Nutr Rev 1984;42:223-5.

3. Carruth BR, Skinner JD. The role of dietary calcium and other nutrients in moderating body fat in preschool children. Int J Obes Relat Metab Disord 2001;25:559-66.

4. Lin YC, Lyle RM, McCabe LD, McCabe GP, Weaver CM, Teegarden D. Dairy calcium is related to changes in body composition during a two-year exercise intervention in young women. J Am Coll Nutr 2000;19:754-60.

5. Heaney RP. Normalizing calcium intake: projected population effects for body weight. J Nutr 2003;133:268S-270S.

6. Teegarden D. Calcium intake and reduction in weight or fat mass. J Nutr 2003;133:249S-251S.

7. Barr SI. Increased dairy product or calcium intake: is body weight or composition affected in humans? J Nutr 2003;133:245S-248S.

8. Barr SI, McCarron DA, Heaney RP, et al. Effects of increased consumption of fluid milk on energy and nutrient intake, body weight, and cardiovascular risk factors in healthy older adults. J Am Diet Assoc 2000;100:810-7.

9. Melanson EL, Sharp TA, Schneider J, Donahoo WT, Grunwald GK, Hill JO. Relation between calcium intake and fat oxidation in adult humans. Int J Obes Relat Metab Disord 2003;27:196-203.

10. Zemel MB. Dietary calcium and dairy products accelerate weight and fat loss during energy restriction in obese adults. Nutr W Abstracts 2001:342-3s.

11. Zemel MB. Effects of calcium-fortified breakfast cereal on adiposity in a transgenic mouse model of obesity. Faseb J 2001:598 (abstr.).

12. Shi H, Dirienzo D, Zemel MB. Effects of dietary calcium on adipocyte lipid metabolism and body weight regulation in energy-restricted aP2-agouti transgenic mice. Faseb J 2001;15:291-3.

13. Zemel MB. Role of calcium and dairy products in energy partitioning and weight management. Am J Clin Nutr 2004;79:907S-12S.

14. Xue B, Moustaid N, Wilkison WO, Zemel MB. The agouti gene product inhibits lipolysis in human adipocytes via a Ca2+-dependent mechanism. Faseb J 1998;12:1391-6.

15. Sun X, Zemel MB. Calcium and Dairy Products Inhibit Weight and Fat Regain during Ad Libitum Consumption Following Energy Restriction in Ap2-Agouti Transgenic Mice. J Nutr 2004;134:3054-60.

16. Xue B, Greenberg AG, Kraemer FB, Zemel MB. Mechanism of intracellular calcium $([\mathrm{Ca} 2+] \mathrm{i})$ inhibition of lipolysis in human adipocytes. Faseb J 2001;15:2527-9.

17. Xue B, Zemel MB. Relationship between human adipose tissue agouti and fatty acid synthase (FAS). J Nutr 2000;130:2478-81.

18. Zemel MB. Mechanisms of dairy modulation of adiposity. J Nutr 2003;133:252S-256S.

19. Borsheim E, Lonnroth P, Knardahl S, Jansson PA. No difference in the lipolytic response to betaadrenoceptor stimulation in situ but a delayed increase in adipose tissue blood flow in moderately obese compared with lean men in the postexercise period. Metabolism 2000;49:579-87.

20. Goossens GH, Blaak EE, Saris WH, van Baak MA. Angiotensin II-induced effects on adipose and skeletal muscle tissue blood flow and lipolysis in normal-weight and obese subjects. J Clin Endocrinol Metab 2004;89:2690-6.

21. Ellershaw DC, Gurney AM. Mechanisms of hydralazine induced vasodilation in rabbit aorta and pulmonary artery. Br J Pharmacol 2001;134:621-31.

22. Carroll JF, King JW, Cohen JS. Hydralazine treatment alters body composition in the rabbit model of obesity. Acta Physiol Scand 2004;181:183-91.

23. Stahle L, Segersvard S, Ungerstedt U. A comparison between three methods for estimation of extracellular concentrations of exogenous and endogenous compounds by microdialysis. J Pharmacol Methods 1991;25:41-52.

24. Arner P, Bulow J. Assessment of adipose tissue metabolism in man: comparison of Fick and microdialysis techniques. Clin Sci (Lond) 1993;85:247-56.

25. Hickner RC, Rosdahl H, Borg I, Ungerstedt U, Jorfeldt L, Henriksson J. Ethanol may be used with the microdialysis technique to monitor blood flow changes in skeletal muscle: dialysate glucose concentration is blood-flow-dependent. Acta Physiol Scand 1991;143:355-6.

26. Zo eet Nederland 1998. Resultaten van de Voedselconsumptiepeiling 1998. Den Haag: Van Marken Delft Drukkers, 1998. 
27. Bell NH, Epstein S, Greene A, Shary J, Oexmann MJ, Shaw S. Evidence for alteration of the vitamin Dendocrine system in obese subjects. J Clin Invest 1985;76:370-3.

28. Zemel MB. Regulation of adiposity and obesity risk by dietary calcium: mechanisms and implications. J Am Coll Nutr 2002;21:146S-151S.

29. Zemel MB, Miller SL. Dietary calcium and dairy modulation of adiposity and obesity risk. Nutr Rev 2004;62:125-31.

30. Zemel MB, Richards J, Mathis S, Milstead A, Gebhardt L, Silva E. Dairy augmentation of total and central fat loss in obese subjects. Int J Obes Relat Metab Disord 2005;29:391-7.

31. Zemel MB, Thompson W, Milstead A, Morris K, Campbell P. Calcium and Dairy Acceleration of Weight and Fat Loss during Energy Restriction in Obese Adults. Obes Res 2004;12:582-90.

32. Zhang Q, Tordoff MG. No effect of dietary calcium on body weight of lean and obese mice and rats. Am J Physiol Regul Integr Comp Physiol 2004;286:R669-77.

33. Bowen J, Noakes M, Clifton PM. Effect of calcium and dairy foods in high protein, energy-restricted diets on weight loss and metabolic parameters in overweight adults. Int J Obes Relat Metab Disord 2005.

34. Harvey-Berino J, Gold BC, Lauber R, Starinski A. The impact of calcium and dairy product consumption on weight loss. Obes Res 2005;13:1720-6.

35. Haub MD, Simons TR, Cook CM, Remig VM, Al-Tamimi EK, Holcomb CA. Calcium-fortified beverage supplementation on body composition in postmenopausal women. Nutr J 2005;4:21.

36. Parra PP, A. Serra, F. Effects of dietary calcium supplementation on body weight in mice. ECO. Athens, 2005:51.

37. Thompson WG, Rostad Holdman N, Janzow DJ, Slezak JM, Morris KL, Zemel MB. Effect of energyreduced diets high in dairy products and fiber on weight loss in obese adults. Obes Res 2005;13:134453.

38. Boon N, Hul GBJ, Sicard A, et al. The effects of short term cholecalciferol supplementation on energy metabolism and fat oxidation and adipose tissue mRNA expression of lipid-metabolism related proteins. Obes Res (under review) 2005.

39. Boon N, Hul GBJ, Viguerie N, Sicard A, Langin D, Saris WHM. The effects of three diets with various calcium contents on 24-hour energy-expenditure, fat oxidation and adipose tissue mRNA expression of lipid-metabolism related proteins. (accepted). American Journal of Clinical Nutrition 2005.

40. Ni Z, Smogorzewski M, Massry SG. Effects of parathyroid hormone on cytosolic calcium of rat adipocytes. Endocrinology 1994;135:1837-44. 


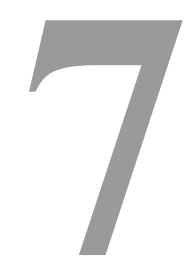

\section{An intervention study of the effects of calcium intake on faecal fat excretion, energy metabolism and adipose tissue mRNA expression of lipid-metabolism related proteins}

Niels Boon ${ }^{1}$, Gabby B.J. Hul ${ }^{1}$, Jos H.C.H. Stegen ${ }^{1}$, Wendy E.M. Sluijsmans ${ }^{1}$, Carine Valle $^{2,3}$, Dominique Langin ${ }^{2,3,4}$, Nathalie Viguerie ${ }^{2,3}$, Wim H.M. Saris ${ }^{1}$

${ }^{1}$ Nutrition and Toxicology Research Institute Maastricht, University of Maastricht, Maastricht, The Netherlands

${ }^{2}$ Inserm, U586, Unité de Recherches sur les Obésités, Toulouse, F-31432 France.

${ }^{3}$ Université Paul Sabatier, Institut Louis Bugnard IFR31, Toulouse, F-31432 France.

${ }^{4} \mathrm{CHU}$ de Toulouse, Laboratoire de Biochimie, Institut Fédératif de Biologie de Purpan, Toulouse, F-31059 France.

Int J Obes 2007: under review 


\begin{abstract}
Context: In various observational studies, an inverse relation between calcium intake and body weight has been observed. A possible explanation could be an increased calcium excretion through the faeces caused by an increased dietary calcium intake.

Objective: To examine whether an increased calcium intake could lead to changes in faecal fat and energy excretion.

Design: Four different isocaloric diets with various calcium contents $(400 \mathrm{mg}, 1200 \mathrm{mg}$ and $2500 \mathrm{mg}$ from dairy and $1200 \mathrm{mg}$ from calcium carbonate (1200S)) were administered in a cross-over design for 7 days each.

Subjects: Five healthy men and five healthy women (age 28 \pm 2 , BMI 24.1 \pm 0.4 , Body fat $\% 25.6 \pm 2.4$ ) were recruited by local announcement.

Measurements: At the end of every intervention period, faecal samples were collected for determination of fat, energy and calcium content, blood samples were obtained for determination of relevant blood parameters and fat samples were obtained for measurement of the mRNA expression. Furthermore, resting energy expenditure and fat oxidation were measured with the ventilated hood technique.

Results: We observed a non-significant $56 \%$ increase in fat excretion $(p=0.159)$ on the $2500 \mathrm{mg}$ diet, compared to the $400 \mathrm{mg}$ diet. The $2500 \mathrm{mg}$ diet significantly reduced the expression of FAS mRNA $(\mathrm{p}<0.05)$ and the calcium content of the diets significantly affected calcium excretion. Furthermore, we saw a significant decrease of serum triglycerides on the $1200 \mathrm{~S}$ diet $(\mathrm{p}<0.05)$.

Conclusion: In this study, we observed a trend towards a higher fat excretion on the

82 high calcium diet, but this difference failed to reach statistical significance. It is possible that the relatively high protein content of the experimental diets increased calcium absorption from the intestine, thus decreasing the amount of calcium available for binding to fat and eliminating possible effects of dietary calcium on fat excretion. Furthermore, we observed decreases in FAS mRNA expression and serum triglycerides as a result of a high calcium intake.
\end{abstract}

Key words: dietary calcium, faecal fat excretion, adipose tissue, obesity. 


\section{Introduction}

Since the publication of an epidemiological investigation in which an unexpected inverse relation was observed between dairy and/or calcium intake and body weight (1), a large number of different types of investigations has been published to study the relation of calcium and body weight. In a number of epidemiological investigations performed in populations with very different characteristics (young women, preschool children, African-Americans, etc.) similar effects were observed (2-7).

A hypothesis to explain this relation was deducted by Zemel et al. from animal and in vitro studies (8); The increased concentration of $1,25-\mathrm{OH}_{2} \mathrm{D}_{3}$ caused by a decreased calcium or dairy intake could cause acute increases of the intracellular calcium concentration $(9,10)$, thus increasing body weight via a decrease in lipolysis and an increase in lipogenesis (11).

To test this hypothesis, obese mice $(12,13)$, and obese humans $(14-16)$ were given diets with different concentrations and types of calcium. In some of these studies beneficial effects of increasing calcium and dairy intake on weight loss were observed $(12,13$, $16)$, whereas in others no effects were observed $(15,17)$. Moreover, no effects of increasing dietary calcium intake on energy expenditure or fat oxidation were observed in a number of investigations studying humans or rodents in energy balance $(18,19)$.

Interestingly, in one of these investigations, a marked increase in faecal fat excretion (from 6.0 to $14.2 \mathrm{~g} /$ day, when calcium intake was increased by $\sim 1250 \mathrm{mg} /$ day) was observed on a diet with a normal protein content (19). An increased calcium intake could lead to an increased calcium concentration in the intestine, which in turn causes an increased binding of fatty acids and bile acids. This leads to the formation of insoluble calcium-fatty acid soaps, which are excreted through the faeces. An increased faecal fat excretion as a result of an increased calcium intake had been observed previously in a number of investigations, but in these studies, the magnitude of the effect was smaller, with increases of up to $4 \mathrm{~g} /$ day $(20,21)$.

Because the effects of calcium intake on faecal fat excretion mentioned above show quite a large variation, confirmation of the quantitative importance of this mechanism is needed. If the effects on faecal fat excretion are indeed as large as in the study by Jacobsen et al., this would shed new light on the relation between dairy intake and body weight.

So the primary endpoint of the present study was to investigate the relation between dietary calcium intake and faecal fat and energy excretion. Furthermore, faecal and urinary calcium excretion were measured as well in order to determine the effects of calcium intake on calcium excretion. We also determined if possible changes in faecal fat excretion could lead to differences in plasma parameters related to fat metabolism. In order to verify the results of our two previous investigations $(18,22)$, we also determined resting fat oxidation, energy expenditure and adipose tissue mRNA expression of genes involved in fat metabolism as suggested by Zemel. 


\section{Methods}

\section{Subjects}

Ten healthy subjects (5 male, 5 female), age $28 \pm 2$, BMI $24.1 \pm 0.4$, Body fat $\% 25.6 \pm 2.4$ participated in this experiment. The nature and the risks of the experimental procedures were explained to them and their informed consent was obtained.

Table 1: Energy (MJ/day) and macronutrient composition, dietary fiber (g/day), calcium (mg/day) and vitamin $\mathrm{D}(\mu \mathrm{g} /$ day $)$ content of habitual and experimental diets $(7$ days $)(\mathrm{n}=10)$

\begin{tabular}{lccccc}
\hline \multicolumn{5}{c}{ Diet } \\
\hline Energy intake & Habitual & 400 & 1200 & 2500 & $1200 \mathrm{~s}$ \\
\%PRO & $10.2 \pm 0.9$ & $10.4 \pm 0.4$ & $10.5 \pm 0.4$ & $10.4 \pm 0.4$ & $10.4 \pm 0.4$ \\
\%CHO & $17.4 \pm 0.1^{1}$ & $20.1 \pm 0.1$ & $20.2 \pm 0.1$ & $20.5 \pm 0.1$ & $20.1 \pm 0.2$ \\
\%FAT & $49.4 \pm 0.3^{1}$ & $45.3 \pm 0.3$ & $45.2 \pm 0.2$ & $45.0 \pm 0.1$ & $45.1 \pm 0.2$ \\
Dietary fiber & $33.3 \pm 0.2$ & $34.7 \pm 0.2$ & $34.6 \pm 0.2$ & $34.4 \pm 0.1$ & $34.8 \pm 0.2$ \\
Calcium & $26.0 \pm 3.3$ & $33.1 \pm 1.2$ & $29.6 \pm 1.0$ & $28.5 \pm 1.2$ & $32.5 \pm 1.2$ \\
vitamin D & $1183 \pm 112^{2}$ & $348 \pm 9^{3}$ & $1242 \pm 5^{4}$ & $2545 \pm 13^{3}$ & $1242 \pm 5^{4}$ \\
\hline
\end{tabular}

All values are mean \pm SEM; ${ }^{1}$ Significantly different from experimental diets $(\mathrm{P}<0.001)$; ${ }^{2}$ Significantly different from 400 and 2500 diets $\left(\mathrm{P}<0.0001\right.$ and $\mathrm{p}<0.001$ respectively); ${ }^{3}$ Significantly different from all other diets $(\mathrm{P}<0.0001) ;{ }^{4}$ Significantly different from 400 and 2500 diets $(\mathrm{P}<0.0001)$; ${ }^{5}$ Significantly different from all other diets ( $\mathrm{p}<0.05$ vs. $1200 \mathrm{~s}, \mathrm{p}<0.01$ vs. $400 \& 1200$, $\mathrm{p}<0.0001$ vs. 2500 )

\section{Experimental protocol}

Subjects were studied for 4 periods of 7 days, during which they consumed 4 different diets in a randomized order. These diets were weighed and packed at the research facility and given to the subjects for consumption at home (also see diets).

Before the start of the first intervention period, a 3-day food questionnaire was used for determination of the habitual dietary intake of the subjects. Furthermore, a medical screening was performed in the morning in the fasting state during which body composition was assessed using hydrodensitometry (also see testing procedures) and a baseline blood sample and fat biopsy were obtained for a baseline determination of mRNA expression and relevant blood parameters. Furthermore, measurements of energy expenditure and fat oxidation were performed using indirect calorimetry (also see indirect calorimetry).

At the end of every dietary period, another fat and blood sample was collected in the morning in the fasting state and substrate and energy metabolism were also measured using indirect calorimetry. During the last $72 \mathrm{~h}$ of each dietary intervention period, subjects collected stool samples for determination of fat and $\mathrm{Ca}^{2+}$ excretion and for determination of faecal energy content. They also collected $24 \mathrm{~h}$ samples of urine for determination of the $\mathrm{Ca}^{2+}$ excretion. Every dietary period was followed by a wash out period of 7 days for the male subjects. Female subjects were studied in the same phase of their menstrual cycle, i.e. once every four weeks. During the wash out period, subjects were allowed to consume their habitual diets, but they were required to keep their diet constant among all wash out periods. During the three following intervention periods, these measurements were repeated. 


\section{Testing procedures}

Before the beginning of the first dietary intervention period, anthropometric measurements were carried out in the fasted state.

\section{Densitometry}

Whole body density was determined by underwater weighing in the morning in the fasted state. Body weight was measured with a digital balance with an accuracy of 0.01 $\mathrm{kg}$ (Sauter, type E1200) and height was measured to the nearest $0.001 \mathrm{~m}$. Lung volume was measured simultaneously with the helium dilution technique using a spirometer (Volugraph 2000, Mijnhardt).

\section{Indirect calorimetry}

Subjects were instructed to report to the laboratory without performing any strenuous exercise after an overnight fast for the indirect calorimetry measurements. Using a ventilated-hood system (Omnical, Maastricht University, the Netherlands), measurements of $\mathrm{VO}_{2}$ and $\mathrm{VCO}_{2}$ were performed for $45 \mathrm{~min}$ at an environmental temperature of $22-24^{\circ} \mathrm{C}$ while subjects were semi-supine. To eliminate the effects of subject habituation to the testing procedure, the respiratory measurements during the first $10 \mathrm{~min}$ were not used. The last $15 \mathrm{~min}$ of the $45 \mathrm{~min}$ of measurement were excluded because the subjects became more restless at the end of the measurement. The ventilated hood measurements from 10 to 30 minutes were used to calculate resting energy expenditure and fat oxidation as previously described. (23)

Gas analyses were performed by dual paramagnetic $\mathrm{O}_{2}$ analyzers and dual infrared $\mathrm{CO}_{2}$ analyzers (type 1156, 1507, 1520; Servomex, Crowborough, Sussex, UK), similar to the analysis system described by Schoffelen et al. (24). Respiratory gas measurements were corrected for standard temperature, pressure and dry conditions. The Weir equation was used to convert $\mathrm{VO}_{2}$ and $\mathrm{VCO}_{2}$ values to energy expenditure (EE) values (25). Fat oxidation was also calculated from the indirect calorimetry values (26).

\section{Biochemical methods}

\section{Fat samples}

After fat biopsies were obtained, blood and connective tissue were washed off with a sterile $0.9 \% \mathrm{NaCl}$ solution, consequently fat tissue was weighed and homogenized in 1 $\mathrm{mL}$ of a $1 \%$ solution of $\beta$-mercaptoethanol in RLT-buffer (RNeasy midi kit, Qiagen Inc) per $1000 \mathrm{mg}$ of fat tissue, frozen immediately in liquid nitrogen and stored at $-80^{\circ} \mathrm{C}$ until further analysis. For a further description of the methods used to determine adipose tissue mRNA expression, also see below.

\section{Blood samples}

After blood samples were drawn they were centrifuged at $4.000 \times \mathrm{G}$ for 10 minutes, aliquots of EDTA plasma were frozen in liquid nitrogen and stored at $-80^{\circ} \mathrm{C}$ until further analysis.

Total plasma free fatty acids, triacylglycerol, total cholesterol, HDL and LDL cholesterol concentrations in the blood samples were measured using standard enzymatic techniques (for plasma free fatty acids: Sigma Diagnostics, St. Louis, MO, for triacylglycerol: GPO trinder kit, Sigma Diagnostics, St. Louis, MO, for total, HDL 
and LDL cholesterol: Cholesterol 100 kit, ABX pentra, Montpeillier, France) automated on a Cobas MIRA centrifugal analyser at $340 \mathrm{~nm}$.

\section{Stool and urine samples}

All faeces excreted were collected in pre-weighed containers during the last 3 days of each diet-period. Subjects were provided with dry ice to allow them to freeze their faecal samples immediately. In addition, the subjects completed a questionnaire on daily defecation frequency during every diet-period. Before analysis, the samples were freeze-dried and homogenized, and samples from the same diet-period were pooled. Faecal energy was determined using a bomb calorimeter (Ika-calorimeter system C4000 Heitersheim, Germany). Before fat content was measured the samples were acid hydrolyzed with $3 \mathrm{~N} \mathrm{HCl}$. Total fat content was measured with a method modified after Bligh \& Dyer (27).

The concentration of calcium in the faecal and urinary samples was determined using an ICP-AES analyzer (Varian Inc., Middelburg, The Netherlands).

Quantification of messenger RNAs in human adipose tissue biopsies using RT-qPCR

Total RNA was extracted from adipose tissue biopsies using the RNeasy Mini kit (Qiagen, Courtaboeuf, France). First-strand cDNAs were first synthesized from $200 \mathrm{ng}$ total RNA in the presence of 100 units of Superscript II reverse transcriptase (Invitrogen, Cergy Pontoise, France) using random hexamer primers (Promega, Charbonnières, France). Real-time quantitative polymerase chain reactions (qPCR) were performed on a GeneAmp 7000 Sequence Detection System (Applied Biosystems, Foster City, CA, USA). Ten ng of cDNA were used as template for real-time PCR. The thermal cycler parameters for the real-time PCR were $2 \mathrm{~min}$ at $50^{\circ} \mathrm{C}$ followed by 40 cycles with $10 \mathrm{sec}$ at $95^{\circ} \mathrm{C}$ and $1 \mathrm{~min}$ at $60^{\circ} \mathrm{C}$. For each primer pair, a standard curve was obtained using serial dilutions of human adipose tissue cDNA prior to mRNA quantitation. A dissociation curve was generated at the end of the PCR cycles to verify that a single gene product was amplified. For $U C P_{2}, F A S, G P D H 2, H S L$ and PPAR $\gamma$ the Taqman approach was used. Both primers and TaqMan ${ }^{\mathrm{TM}}$ probes were obtained from Applied Biosystems (Foster City, CA, USA). The probes were labeled with a reporter dye (FAM) on the $5^{\prime}$ end. The probe for $18 \mathrm{~S}$ ribosomal RNA was labeled with the reporter dyes VICTM and TAMRA on the $5^{\prime}$ end and the $3^{\prime}$ end, respectively. For Taqman assays, because of very high specificity of the method, check for non-specific product formation with a dissociation curve is not needed. We used 18S rRNA as control to normalize gene expression using the Ribosomal RNA Control TaqMan ${ }^{\mathrm{TM}}$ Assay kit (Applied Biosystems, Foster City, CA, USA). All reactions were performed in duplicate.

\section{Diets}

During the four 7-day dietary intervention periods, subjects received four different diets for consumption at home. These diets were isocaloric and they consisted of $35 \%$ (energy percent) fat, $20 \%$ protein and $45 \%$ carbohydrate as calculated using the Dutch Food composition chart (28). The food items in these diets were similar to those regularly incorporated in the Dutch diet, and dietary fiber was matched between the different diets, so the only difference between the four diets was the source and concentration of calcium. The calcium source and concentration of the intervention diets was as follows:

Calcium concentration diet $1=400 \mathrm{mg} /$ day

Calcium concentration diet $2=1200 \mathrm{mg} /$ day (low-fat dairy) 
Calcium concentration diet $3=2500 \mathrm{mg} /$ day (low-fat dairy)

Calcium concentration diet $4=1200 \mathrm{mg} /$ day $\left(\mathrm{CaCO}_{3}\right)$

The energy requirements of the subjects were determined by using the Harris and Benedict equations and multiplying the outcome of these calculations by 1.6 to adjust for daily physical activity:

BMRmen $=0.28+2.093 \times \mathrm{H}+0.058 \times \mathrm{BM}-0.028 \times \mathrm{A}$

BMRwomen $=2.74+0.774 \times \mathrm{H}+0.040 \times \mathrm{BM}-0.020 \times \mathrm{A}$

In which BMR is Basal Metabolic Rate in $\mathrm{MJ} /$ day, $\mathrm{H}$ is height in $\mathrm{m}, \mathrm{BM}$ is body mass in $\mathrm{kg}$ and $\mathrm{A}$ is age in years (29).

Subjects received a written and oral instruction every time when the diets were handed out, along with a meal-to-meal description of all food items that were to be consumed. All food items were weighed and packed at the research facility and were handed out to the subjects on days 1 and 4 of the dietary intervention periods. Subjects were instructed to write down all deviations from the diets and to report all problems immediately to the researcher. Furthermore, compliance to the diets was checked with interviews and subjects were instructed to return all the items they did not consume on their visits to the research facility on days 4 and 7 of the intervention periods. These returned food items were not included in the calculation of the total dietary intake during the experimental periods. In general, no major deviations from the diets were reported, i.e. these deviations did not affect the macronutrient composition and calcium content of the diets.

\section{Statistical analysis}

Statistical power analysis and data from previously published, similar research (19) indicated that a minimum of 10 subjects was required in order to attain a statistical power of $1-\beta=0.90$, assuming a difference in faecal fat excretion of $6 \mathrm{~g} /$ day between the diets with the highest and the lowest calcium concentration and a standard deviation of $3.5 \mathrm{~g} / \mathrm{day}$.

Possible significant differences in faecal and urine parameters, in energy and substrate metabolism, between the habitual and experimental diets and in mRNA expression induced by the four different diets with a repeated measures ANOVA and a Scheffé test was used for post-hoc analysis. Fiber and fat intake were included as covariates in the analyses of faecal fat and energy excretion. A two-factor ANOVA was used to determine differences in blood parameters before and after the diets. Statistical difference was set at $\mathrm{p}<0.05$.

\section{Results}

\section{Habitual dietary intake}

The subjects had an average energy consumption of 10.2 $\pm 0.9 \mathrm{MJ}$ per day, which was consumed as $17.4 \pm 0.1 \%$ from protein, $49.4 \pm 0.3 \%$ from carbohydrate and $33.3 \pm 0.2 \%$ from fat. The habitual daily calcium intake of these subjects was $1183 \pm 112 \mathrm{mg}$, the dietary fiber intake of the subjects was $26.0 \pm 3.3 \mathrm{~g}$ per day and the habitual intake of vitamin D was $1.8 \pm 0.4 \mu \mathrm{g} /$ day (table 1 ). 


\section{Experimental diets}

All subjects completed the three different dietary regimens without any adverse effects of the diets. The average energy intake during the 7 days of the dietary interventions was $10.4 \pm 0.4,10.5 \pm 0.4$ and $10.4 \pm 0.4$ and $10.4 \pm 0.4 \mathrm{MJ} /$ day for the $400,1200,2500$ and 1200 s diets, respectively. The experimental diets only differed in calcium concentration $(\mathrm{P}<0.0001,400$ vs. 1200 and 1200s, 2500 vs. 1200 and 1200s, 400 vs. 2500). All of the experimental diets contained significantly more protein and less carbohydrates $(\mathrm{P}<0.001)$ and significantly more vitamin $\mathrm{D}(\mathrm{P}<0.001)$ than the subjects' habitual diets (table 1).

\section{Metabolic measurements}

The relative contribution of fat oxidation to the resting energy expenditure was $57 \pm 6$, $59 \pm 2,64 \pm 7,60 \pm 6$ and $61 \pm 4 \%$ at the screening and at the end of the $400,1200,2500$ and 1200 s experimental periods, respectively. None of these differences were statistically significant. (figure 1)

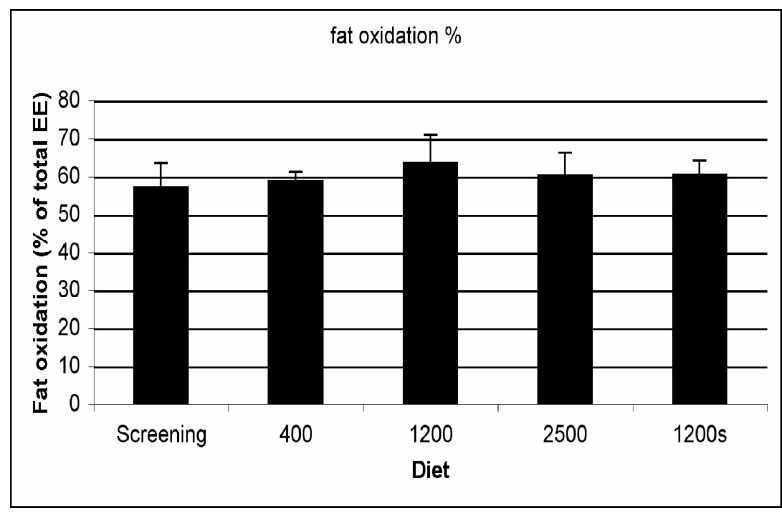

Figure 1: Contribution of fat oxidation to total resting metabolic rate $(R M R),(n=10)$. None of these differences were statistically significant.

RMR values were $8.0 \pm 0.5,7.0 \pm 0.4,7.5 \pm 0.4,6.9 \pm 0.4$ and $8.0 \pm 0.8 \mathrm{MJ} / 24 \mathrm{~h}$ at the screening and at the end of the 400, 1200, 2500 and 1200s experimental periods, respectively and 24 hour fat oxidation at these time points was $117 \pm 19,106 \pm 8,117 \pm 12$, $107 \pm 13$ and $122 \pm 13 \mathrm{~g} / 24 \mathrm{~h}$. None of these differences were statistically significant. (figure 2)

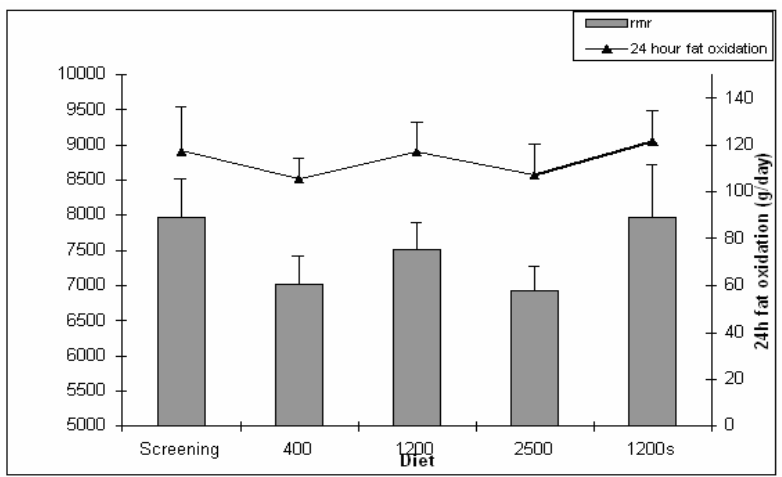

Figure 2: Resting metabolic rate (RMR) $(\mathrm{kJ} /$ day) and 24 hour fat oxidation (g/day) values as calculated from the indirect calorimetry measurements, $(n=10)$. None of these differences were statistically significant. 


\section{Plasma parameters}

No differences between the four diets were observed in fasting plasma concentrations of FFA, glucose, free glycerol, HDL cholesterol, total cholesterol, serum calcium and serum $1,25-\mathrm{OH}_{2} \mathrm{D}_{3}$. A significant decrease in serum triglycerides from $1253 \pm 201$ to $670 \pm 75 \mu \mathrm{mol} / 1$ was observed in response to the 1200 s diet $(\mathrm{P}<0.05)$. All values were within the normal range. (table 2)

Table 2: Plasma values of free fatty acids (FFA), glucose, free glycerol, HDL cholesterol, total cholesterol, triglycerides, serum calcium and serum $1,25 \mathrm{OH}_{2} \mathrm{D}_{3}$

\begin{tabular}{lcccccc}
\hline Diet & \multicolumn{2}{c}{ FFA $(\mu \mathrm{mol} / \mathrm{l})$} & \multicolumn{2}{c}{ Glucose $(\mathrm{mmol} / \mathrm{l})$} & \multicolumn{2}{c}{ Free glycerol $(\mu \mathrm{mol} / \mathrm{l})$} \\
\hline & Pre & Post & Pre & Post & Pre & Post \\
400 & $361 \pm 82$ & $387 \pm 61$ & $5.10 \pm 0.12$ & $5.06 \pm 0.14$ & $108 \pm 16$ & $104 \pm 15$ \\
1200 & $241 \pm 110$ & $279 \pm 41$ & $5.19 \pm 0.55$ & $5.02 \pm 0.12$ & $111 \pm 9$ & $86 \pm 9$ \\
2500 & $277 \pm 41$ & $263 \pm 32$ & $5.27 \pm 0.17$ & $4.98 \pm 0.09$ & $104 \pm 11$ & $86 \pm 6$ \\
$1200 \mathrm{~s}$ & $351 \pm 84$ & $303 \pm 69$ & $5.26 \pm 0.14$ & $4.93 \pm 0.13$ & $119 \pm 21$ & $92 \pm 12$ \\
& HDL cholesterol (mmol/1) & Total cholesterol $(\mathrm{mmol} / 1)$ & Triglycerides $(\mu \mathrm{mol} / 1)$ \\
400 & Pre & Post & Pre & Post & Pre & Post \\
1200 & $1.28 \pm 0.05$ & $1.22 \pm 0.06$ & $4.28 \pm 0.26$ & $3.98 \pm 0.19$ & $1049 \pm 307$ & $797 \pm 180$ \\
2500 & $1.36 \pm 0.09$ & $1.24 \pm 0.07$ & $4.43 \pm 0.23$ & $4.18 \pm 0.27$ & $1046 \pm 167$ & $783 \pm 134$ \\
$1200 \mathrm{~s}$ & $1.41 \pm 0.08$ & $1.31 \pm 0.09$ & $4.30 \pm 0.23$ & $4.26 \pm 0.31$ & $1070 \pm 206$ & $741 \pm 103$ \\
& $1.40 \pm 0.05$ & $1.31 \pm 0.06$ & $4.43 \pm 0.25$ & $4.30 \pm 0.23$ & $1253 \pm 201$ & $670 \pm 75^{1}$ \\
& Calcium $(\mathrm{mmol} / 1)$ & $1,25-\mathrm{OH} 2 \mathrm{D} 3(\mathrm{pmol} / \mathrm{l})$ & & \\
400 & Pre & Post & Pre & Post & & \\
1200 & $2.26 \pm 0.03$ & $2.22 \pm 0.01$ & $123 \pm 9$ & $126 \pm 8$ & & \\
2500 & $2.29 \pm 0.03$ & $2.24 \pm 0.02$ & $110 \pm 10$ & $116 \pm 12$ & & \\
$1200 \mathrm{~s}$ & $2.24 \pm 0.02$ & $2.23 \pm 0.02$ & $115 \pm 7$ & $108 \pm 5$ & & \\
\hline
\end{tabular}

All values are mean $\pm \mathrm{SEM} ;{ }^{1}$ Denotes a significant difference from the pre-values $(\mathrm{P}<0.05)$

\section{Faecal and urinary parameters}

Although a dose dependant increase in both the faecal energy as well as in the faecal fat content in relation to the calcium intake was observed, these differences were not statistically significant. The faecal energy content of the diets was $571 \pm 70,584 \pm 76$, $642 \pm 85$ and $631 \pm 69 \mathrm{~kJ} /$ day, for the $400,1200,2500$ and 1200 s diets, respectively. The faecal fat excretion was $4.8 \pm 0.8,7.2 \pm 1.1,7.5 \pm 1.0$ and $6.7 \pm 1.2 \mathrm{~g} /$ day for the 400,1200 , 2500 and 1200 s diets, respectively (table 3 ).

Table 3: Faecal energy and fat content

\begin{tabular}{lcc}
\hline Diet & Energy $(\mathrm{kJ} / \mathrm{d})$ & Fat $(\mathrm{g} / \mathrm{d})$ \\
\hline 400 & $571 \pm 70$ & $4.8 \pm 0.8$ \\
1200 & $584 \pm 76$ & $7.2 \pm 1.1$ \\
2500 & $642 \pm 85$ & $7.5 \pm 1.0$ \\
$1200 \mathrm{~s}$ & $631 \pm 69$ & $6.7 \pm 1.2$ \\
\hline
\end{tabular}

All values are mean \pm SEM; None of these differences were statistically significant

As expected, the total calcium excretion increased with an increasing calcium intake. On the $400 \mathrm{mg}$ calcium diet, a negative calcium balance was observed, whereas on the other calcium diets, a positive calcium balance was observed. For details, see table 4 . 
Table 4: Faecal and urinary calcium excretion

\begin{tabular}{lccc}
\hline Diet & $\begin{array}{c}\text { Urinary calcium } \\
\text { excretion (mg/day) }\end{array}$ & $\begin{array}{c}\text { Faecal calcium excretion } \\
\text { (mg/day) }\end{array}$ & $\begin{array}{c}\text { Total calcium excretion } \\
\text { (mg/day) }\end{array}$ \\
\hline 400 & $169 \pm 25^{1}$ & $432 \pm 87$ & $601 \pm 705$ \\
1200 & $205 \pm 33^{2}$ & $752 \pm 82$ & $957 \pm 756$ \\
2500 & $271 \pm 49^{3}$ & $1409 \pm 20^{6}$ & $1680 \pm 208^{7}$ \\
$1200 \mathrm{~s}$ & $196 \pm 35^{4}$ & $839 \pm 82$ & $1036 \pm 104^{8}$ \\
\hline
\end{tabular}

All values are mean \pm SEM; ${ }^{1}$ Denotes a significant difference from the $1200,1200 \mathrm{~s}$ and 2500 diets $(\mathrm{p}<0.01$, $\mathrm{p}<0.01$ and $\mathrm{p}<0.0001$, respectively); ${ }^{2}$ Denotes a significant difference from the 400 and 2500 diets $(\mathrm{p}<0.01$ and $\mathrm{p}=0.01$, respectively); ${ }^{3}$ Denotes a significant difference from the 400,1200 and $1200 \mathrm{~s}$ diets $(\mathrm{p}<0.0001$, $\mathrm{p}=0.01$ and $\mathrm{p}<0.05$, respectively); ${ }^{4}$ Denotes a significant difference from the 400 and 2500 diets $(\mathrm{p}<0.01$ and $\mathrm{p}<0.05$, respectively); ${ }^{5}$ Denotes a significant difference from the $2500 \operatorname{diet}(\mathrm{p}<0.0001)$; ${ }^{6}$ Denotes a significant difference from the 2500 diet $(\mathrm{p}<0.01)$; ${ }^{7}$ Denotes a significant difference from the 400,1200 and 1200 s diets $\left(\mathrm{p}<0.0001, \mathrm{p}<0.01\right.$ and $\mathrm{p}<0.05$, respectively); ${ }^{8}$ Denotes a significant difference from the $2500 \operatorname{diet}(\mathrm{p}<0.05)$

\section{Adipocyte mRNA expression}

The mRNA concentrations in adipose tissue were determined for 8 subjects only, because for 2 subjects, complete sets of biopsies could not be analyzed due to a low mRNA yield. A significant decrease in mRNA expression compared to the screening values was observed in response to the 2500 experimental diet for $F A S(\mathrm{P}<0.05)$. A trend towards a significant decrease was observed in response to the 2500 experimental diet for $H S L$ mRNA expression ( $\mathrm{p}=0.078$ ) (figure 3 ).

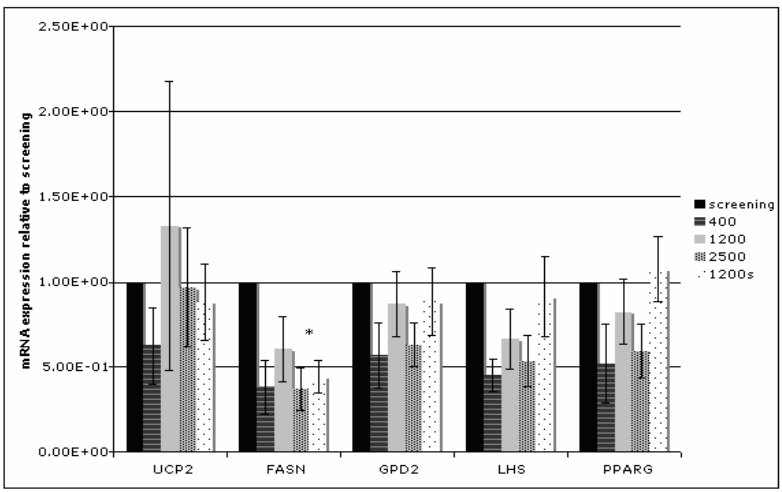

Figure 3: Adipose tissue uncoupling protein 2 (UCP2), fatty acid synthase (FAS), hormone sensitive lipase (HSL), peroxisome proliferator activated receptor gamma (PPARG) and glycerol phosphate dehydrogenase $(\mathrm{GPDH} 2)$ mRNA expression, $(\mathrm{n}=8)$. * Denotes a significant difference from the screening $(\mathrm{P}<0.05)$.

\section{Discussion}

The primary endpoint of this study was to investigate the relation between dietary calcium intake and faecal fat and energy excretion. Furthermore, we also determined the effects of calcium intake on calcium excretion. Thirdly, we investigated if possible changes in faecal fat excretion could lead to differences in plasma parameters related to fat metabolism. Finally, to verify the results of our previous investigations, we also 
determined resting fat oxidation, energy expenditure and adipose tissue mRNA expression.

Although we observed a $56 \%$ higher faecal fat excretion when the $2500 \mathrm{mg}$ diet was compared to the $400 \mathrm{mg}$ diet, this difference was not statistically significant $(p=0.159)$. Furthermore, we also observed a non-significant dose-response relation between calcium intake and fat excretion. A post-hoc power calculation showed that a minimum of 18 subjects would have been necessary to reach statistical significance with the observed differences. So we did not observe any significant differences because of a type II error (i.e. a lack of statistical power), since the effects on fat excretion were not as large as in the previous study upon which our a priori power calculations were based (i.e. the magnitude of the effects we observed is smaller than in the study of Jacobsen et al. who showed an increase in fat excretion of up to $250 \%$ when calcium intake was increased by $1350 \mathrm{mg} /$ day) (19).

The smaller fat binding effect of calcium in all four diets might be the result of the high protein content of the diets. To compare the measurements of energy expenditure and fat oxidation and the mRNA expression data of the present investigation to our previous experiment (18), we choose to use the same relatively high protein content as in that study. This high protein content of the diets was chosen to equalize the macronutrient composition of the experimental diets. A high dairy diet automatically leads to a relatively high protein content. Recently, it has been shown that a high protein intake increases calcium bioavailability, making less calcium available for binding to fat in the intestine (30-33). In the investigation by Jacobsen et al. (19), the significant effects on faecal fat excretion were only observed in the high calcium low protein diets. The faecal energy content of the present investigation is comparable to the condition in the study of Jacobsen with a high protein content (i.e. 23\%), in which they did not observe any effects of increasing calcium intake on fat excretion. Furthermore, the faecal fat concentration in this investigation is in line with previous research $(20,21,34)$. In these studies, the protein content of the diets ranged from 14 to $17 \%$.

As expected, the $400 \mathrm{mg}$ calcium diet induced a negative calcium balance (i.e. the calcium excretion was 1.5 times higher than the calcium intake), whereas on the other three diets approximately $75-80 \%$ of the ingested calcium was excreted through faeces and urine.

The significant change in the serum triglyceride concentration on the 1200 s diet is an interesting observation. An increased fat binding in the intestine, which may have an effect on blood lipids, could cause this difference. However, all of the diets induced a lower triglyceride concentration, so it is more likely that the changed macronutrient intake (carbohydrate intake was decreased and protein intake was increased) caused these effects. The change in the 1200 s diet is significant, however the baseline value is already elevated.

Significant effects of high-calcium or high-dairy diets on postprandial- or 24-hour energy metabolism were described in a few recent publications (35-37), whereas no effects of calcium and dairy intake were observed in this experiment or our previous studies $(18,38)$. However, in those studies (35-37) the subjects were in a negative energy balance (36), or the postprandial or acute effects of calcium and dairy intake were studied $(35,37)$. During energy restriction, energy expenditure is decreased and the potential stimulatory effects of a high calcium intake on energy metabolism (39) could counteract this decrease. Furthermore, the effects of a high calcium intake could also be more acute (i.e. more pronounced postprandially after a high calcium meal). We 
studied the effects of calcium on a 24-hour energy balance and our subjects were in a neutral energy balance, which could explain the differences in results.

In these previous experiments, we did not observe any effects of changing the dietary calcium intake or of direct manipulations of the serum $1,25-\mathrm{OH}_{2} \mathrm{D}_{3}$ concentration on resting fat and energy metabolism, either $(18,38)$. But strikingly, we did observe significant differences in the serum concentration of $1,25-\mathrm{OH}_{2} \mathrm{D}_{3}$, whereas this was not the case in the present investigation. A possible explanation for this discrepancy could be that the baseline values of serum $1,25-\mathrm{OH}_{2} \mathrm{D}_{3}$ in this investigation were markedly lower than those in our previous investigations $(18,38)$. These baseline values were comparable to the values after the high calcium diets in our previous investigation, which probably prevented a further decline in serum $1,25-\mathrm{OH}_{2} \mathrm{D}_{3}$ on the high calcium diets. The lower baseline values could not be explained from the present data, although the slightly higher habitual calcium intake of the subjects in this study (1183 vs. 1027 and $749 \mathrm{mg} /$ day) may have played a role. However, the low basal levels of $1,25-\mathrm{OH}_{2} \mathrm{D}_{3}$ do not explain the absence of differences on the $400 \mathrm{mg}$ diet, so this could also be regarded as an indication of non-adherence to the experimental diets. But the significant differences in calcium excretion and the trend towards a dose-response relation between calcium intake and fat excretion contradict this and furthermore, the subjects were closely monitored during the experimental periods.

Furthermore, we observed that increasing the dietary calcium intake to $2500 \mathrm{mg} /$ day decreased the expression of $F A S$ mRNA and induced a trend towards a lower expression of $H S L$ mRNA in subcutaneous adipose tissue in the abdominal region. These differences in mRNA expression of $F A S$ and $H S L$ could be markers of a reduced adipocyte differentiation as a result of the high calcium concentration of the diet. A reduced adipocyte differentiation has previously been observed in vitro in response to a decreased intracellular calcium concentration, which could be the result of an increased dietary calcium intake (40).

The $2500 \mathrm{mg}$ /day calcium intake meant a significant increase compared to the habitual intake of $1183 \pm 112 \mathrm{mg} /$ day which could explain the significant depression of the FAS mRNA expression observed in this study but not in previous ones in which the changes in calcium intake were not significant when compared to the baseline intake $(18,22)$. Furthermore, the magnitude of the changes in gene expression in this experiment was comparable to the changes in a previous experiment (18), but the larger measurement error could explain the absence of significant differences in the earlier experiment. In the other experiment (22), in which we studied the effects of vitamin D supplementation, the differences in gene expression were much smaller. Nonetheless, the absence of significant changes in the serum $1,25-\mathrm{OH}_{2} \mathrm{D}_{3}$ concentration makes these results puzzling because a change in the FAS mRNA expression would be expected in response to alterations of the serum $1,25-\mathrm{OH}_{2} \mathrm{D}_{3}$ concentration according to in vitro models (39), which could mean that other mechanisms possibly induced the differences in gene expression.

In line with our previous study $(18,38)$, we did not observe any differences in the effects between the two conditions with $1200 \mathrm{mg}$ of calcium from calcium carbonate or dairy, indicating that the source of calcium does not seem to affect the bio-efficacy.

Summarizing the results from this study, increasing the dietary calcium intake in healthy subjects increased the faecal fat excretion by up to $56 \%$, although this difference was not statistically significant. This could be due to a lack of statistical power to detect the observed differences. The effect of increasing calcium intake on faecal energy and fat excretion could also be smaller due to the high protein content of our diets, which 
may have increased the intestinal calcium absorption, making less calcium available for binding to fat. Increasing dietary calcium intake did increase urinary and total $\mathrm{Ca}^{2+}$ excretion and a significant decrease in serum triglycerides was observed in response to the 1200 s diet. Furthermore, we observed a decreased expression of FAS mRNA expression in subcutaneous tissue, but no changes in any of the other parameters we measured. 


\section{References}

1. McCarron DA. Dietary calcium as an antihypertensive agent. Nutr Rev 1984;42:223-5.

2. Lin YC, Lyle RM, McCabe LD, McCabe GP, Weaver CM, Teegarden D. Dairy calcium is related to changes in body composition during a two-year exercise intervention in young women. $\mathrm{J}$ Am Coll Nutr 2000;19:754-60.

3. Shapses SA, Heshka S, Heymsfield SB. Effect of calcium supplementation on weight and fat loss in women. J Clin Endocrinol Metab 2004;89:632-7.

4. Pereira MA, Jacobs DR, Jr., Van Horn L, Slattery ML, Kartashov AI, Ludwig DS. Dairy consumption, obesity, and the insulin resistance syndrome in young adults: the CARDIA Study. Jama 2002;287:20819.

5. Jacqmain M, Doucet E, Despres JP, Bouchard C, Tremblay A. Calcium intake, body composition, and lipoprotein-lipid concentrations in adults. Am J Clin Nutr 2003;77:1448-52.

6. Davies KM, Heaney RP, Recker RR, et al. Calcium intake and body weight. J Clin Endocrinol Metab 2000;85:4635-8.

7. Atkin LM, Davies PS. Diet composition and body composition in preschool children. Am J Clin Nutr 2000;72:15-21.

8. Zemel MB. Role of calcium and dairy products in energy partitioning and weight management. Am J Clin Nutr 2004;79:907S-12S.

9. Xue B, Moustaid N, Wilkison WO, Zemel MB. The agouti gene product inhibits lipolysis in human adipocytes via a Ca2+-dependent mechanism. Faseb J 1998;12:1391-6.

10. Sun X, Zemel MB. Calcium and Dairy Products Inhibit Weight and Fat Regain during Ad Libitum Consumption Following Energy Restriction in Ap2-Agouti Transgenic Mice. J Nutr 2004;134:3054-60.

11. Zemel MB. Nutritional and endocrine modulation of intracellular calcium: implications in obesity, insulin resistance and hypertension. Mol Cell Biochem 1998;188:129-36.

12. Zemel MB. Effects of calcium-fortified breakfast cereal on adiposity in a transgenic mouse model of obesity. Faseb J 2001:598 (abstr.).

13. Shi H, Dirienzo D, Zemel MB. Effects of dietary calcium on adipocyte lipid metabolism and body weight regulation in energy-restricted aP2-agouti transgenic mice. Faseb J 2001;15:291-3.

14. Bowen J, Noakes M, Foster P, Clifton PM. Influence of dairy protein and calcium in energy restricted weight loss diets. 2003.

15. Thompson WG, Rostad Holdman N, Janzow DJ, Slezak JM, Morris KL, Zemel MB. Effect of energyreduced diets high in dairy products and fiber on weight loss in obese adults. Obes Res 2005;13:134453.

16. Zemel MB, Richards J, Mathis S, Milstead A, Gebhardt L, Silva E. Dairy augmentation of total and central fat loss in obese subjects. Int J Obes Relat Metab Disord 2005.

17. Bowen J, Noakes M, Clifton PM. Effect of calcium and dairy foods in high protein, energy-restricted diets on weight loss and metabolic parameters in overweight adults. Int J Obes Relat Metab Disord 2005 .

18. Boon N, Hul GB, Viguerie N, Sicard A, Langin D, Saris WH. Effects of 3 diets with various calcium contents on 24-h energy expenditure, fat oxidation, and adipose tissue message RNA expression of lipid metabolism-related proteins. Am J Clin Nutr 2005;82:1244-52.

19. Jacobsen R, Lorenzen JK, Toubro S, Krog-Mikkelsen I, Astrup A. Effect of short-term high dietary calcium intake on 24-h energy expenditure, fat oxidation, and fecal fat excretion. Int J Obes Relat Metab Disord 2005;29:292-301.

20. Shahkhalili Y, Murset C, Meirim I, et al. Calcium supplementation of chocolate: effect on cocoa butter digestibility and blood lipids in humans. Am J Clin Nutr 2001;73:246-52.

21. Welberg JW, Monkelbaan JF, de Vries EG, et al. Effects of supplemental dietary calcium on quantitative and qualitative fecal fat excretion in man. Ann Nutr Metab 1994;38:185-91.

22. Boon N, Hul GBJ, Sicard A, et al. The effects of short term cholecalciferol supplementation on energy metabolism and fat oxidation and adipose tissue mRNA expression of lipid-metabolism related proteins. Obes Res (in press) 2006.

23. Adriaens MP, Schoffelen PF, Westerterp KR. Intra-individual variation of basal metabolic rate and the influence of daily habitual physical activity before testing. Br J Nutr 2003;90:419-23.

24. Schoffelen PF, Westerterp KR, Saris WH, Ten Hoor F. A dual-respiration chamber system with automated calibration. J Appl Physiol 1997;83:2064-72.

25. Weir J. New methods for calculating metabolic rate with special reference to protein metabolism. Journal of Physiology 1949;109:101-9. 
26. Peronnet F, Massicotte D. Table of nonprotein respiratory quotient: an update. Can J Sport Sci 1991;16:23-9.

27. Bligh EG, Dyer WJ. A rapid method of total lipid extraction and purification. Can J Med Sci 1959;37:911-7.

28. NEVO Table. Voorlichtingsbureau voor de voeding (Netherlands Nutrition Centre). Den Haag: Stichting Nederlands Voedingsstoffenbestand (Netherlands Food Composition Chart), 1996.

29. Harris. A biometric study of basal metabolism in man. Washington: Carnegie institution of Washington, 1919.

30. Kerstetter JE, O'Brien KO, Insogna KL. Dietary protein affects intestinal calcium absorption. Am J Clin Nutr 1998;68:859-65.

31. Kerstetter JE, O'Brien KO, Insogna KL. Dietary protein, calcium metabolism, and skeletal homeostasis revisited. Am J Clin Nutr 2003;78:584S-592S.

32. Kerstetter JE, O'Brien KO, Insogna KL. Low protein intake: the impact on calcium and bone homeostasis in humans. J Nutr 2003;133:855S-861S.

33. Kerstetter JE, Svastisalee CM, Caseria DM, Mitnick ME, Insogna KL. A threshold for low-protein-dietinduced elevations in parathyroid hormone. Am J Clin Nutr 2000;72:168-73.

34. Govers MJ, Termont DS, Lapre JA, Kleibeuker JH, Vonk RJ, Van der Meer R. Calcium in milk products precipitates intestinal fatty acids and secondary bile acids and thus inhibits colonic cytotoxicity in humans. Cancer Res 1996;56:3270-5.

35. Cummings NK, Soares MJ, James AP, Ping-Delfos WC. Comparison of dairy and non-dairy sources of calcium on thermogenesis and substrate oxidation in humans. Asia Pac J Clin Nutr 2004;13:S87.

36. Melanson EL, Donahoo WT, Dong F, Ida T, Zemel MB. Effect of low- and high-calcium dairy-based diets on macronutrient oxidation in humans. Obes Res 2005;13:2102-12.

37. Melanson EL, Sharp TA, Schneider J, Donahoo WT, Grunwald GK, Hill JO. Relation between calcium intake and fat oxidation in adult humans. Int J Obes Relat Metab Disord 2003;27:196-203.

38. Boon N, Hul GB, Sicard A, et al. The effects of increasing serum calcitriol on energy and fat metabolism and gene expression. Obesity (Silver Spring) 2006;14:1739-46.

39. Zemel MB, Shi H, Greer B, Dirienzo D, Zemel PC. Regulation of adiposity by dietary calcium. Faseb J 2000;14:1132-8.

40. Shi H, Halvorsen YD, Ellis PN, Wilkison WO, Zemel MB. Role of intracellular calcium in human adipocyte differentiation. Physiol Genomics 2000;3:75-82. 


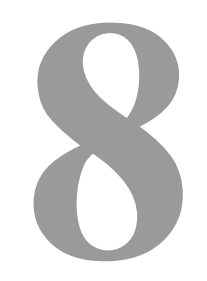

\section{Postprandial plasma amino acid profiles in relation to markers of satiety}

Niels Boon ${ }^{1}$, Janne K. Lorenzen ${ }^{2}$, Jens J. Holst ${ }^{3}$, Jens F. Reheld ${ }^{4}$, Arne V. Astrup ${ }^{2}$, Wim H.M. Saris ${ }^{1}$

${ }^{1}$ Nutrition and Toxicology Research Institute Maastricht, University of Maastricht, Maastricht, The Netherlands

${ }^{2}$ Department of Human Nutrition, Faculty of Life Sciences, University of Copenhagen, Copenhagen, Denmark

${ }^{3}$ Department of Medical Physiology, Panum Institute, University of Copenhagen, Copenhagen, Denmark

${ }^{4}$ Department of Clinical Biochemistry, Rigshospitalet, University Hospital of

Copenhagen, Copenhagen, Denmark

Eur J Clin Nutr 2007: submitted 


\begin{abstract}
Context: Recent studies have shown that meals with a high content of dairy products and/or calcium could increase postprandial fat oxidation and energy expenditure and increase satiety.

Objective: To study if the type of protein in a meal can change the postprandial amino acid response and to investigate if different markers of satiety and glucose metabolism are related to this response.

Design: Two different meals (DAIRY and SOY) with different sources of protein were given in a randomized, crossover design.

Participants: 18 young, healthy, overweight (age $25.7 \pm 1.2$, BMI $27.1 \pm 0.4$ ) volunteers. Measurements: After administration of the meals, plasma amino acids, ghrelin, CCK, glucose and insulin responses were measured, visual analog scale (VAS) measurements of satiety-related parameters were carried out and food intake at a subsequent meal was measured.

Results: We observed significantly higher branched chain amino acid (BCAA) and large neutral amino acid (LNAA) responses in the DAIRY condition compared to the SOY condition and we observed significant relations between the ratio of tryptophan to LNAAs (TRP/LNAA-ratio) and ghrelin and between the ratio of tyrosine to LNAAs (TYR/LNAA-ratio) and cholecystokynine (CCK). No differences in markers of satiety, food intake or plasma glucose metabolism were observed.

Conclusions: We conclude that the protein composition of a meal changed the postprandial BCAA and LNAA responses and that aspects of the postprandial amino acid response are related to the hormonal responses of ghrelin and CCK. However, the protein composition of a meal does not affect markers of satiety or plasma glucose homeostasis.
\end{abstract}

Keywords: postprandial amino acid metabolism, dairy, protein, obesity, satiety, glucose homeostasis 


\section{Introduction}

Obesity is a chronic disease, characterized by an excessive storage of body fat and is associated with many other illnesses, such as insulin resistance and different cardiovascular diseases (1-3). It is directly related to an increased mortality and a lower life expectancy (3). Reducing body weight can be achieved by creating a negative energy balance, either by increasing energy expenditure or by decreasing energy intake. During recent years, a possible role for calcium and dairy in body weight management has received a lot of attention. After the publication of a first epidemiological investigation in which an inverse relation of calcium and body weight was observed (4), this was confirmed in other observational studies (5-10).

A number of mechanisms have been proposed to explain this relation between calcium and dairy intake and body weight. Firstly, changes in serum calcitriol metabolism could lead to increases in fat oxidation and energy expenditure, but this mechanism was not confirmed in clinical trials $(11,12)$. Alternatively, an increased calcium intake could also increase fecal fat excretion, thus decreasing the delivery of dietary fat and thus energy to the systemic circulation (12-14).

Another explanation may lie in the protein component of dairy, since dairy protein and specifically the whey component could have beneficial effects on satiety. An increased satiety after a meal could reduce energy intake at a consequent meal thus reducing food intake. It has been shown that the source of protein of a preload meal affects satiety and food intake at a consequent meal, with animal sources (i.e. dairy or meat protein) being more satiating than protein from plant origin (i.e. soy or vegetable protein) (15-17).

Furthermore, the high concentration of BCAAs (leucine, isoleucine and valine) present in dairy products could increase the postprandial concentration of these amino acids, which could have beneficial effects on body composition and energy metabolism, for example through an increased postprandial protein uptake and protein synthesis in muscle tissue or the effects of leucine on the preservation of lean mass during energy restriction (18-20).

It has also been reported that the LNAAs (phenylalanine, methionine, histidine, valine, isoleucine, leucine, tyrosine, tryptophan and phenylalanine) share a common lowaffinity transport mechanism for transport across the blood-brain barrier. This could mean that a high total plasma concentration of these LNAAs decreases the transport of tryptophan and tyrosine across the blood-brain barrier. Tryptophan and tyrosine are necessary for the formation of the neurotransmitters serotonine and catecholamines, respectively (21), which have been suggested to play a role in satiety (22). Interestingly, a few studies have reported a relation between satiety and the ratio of tyrosine or tryptophan to the total LNAA concentration $(23,24)$. Furthermore, dairy protein has a high content of LNAAs so this way, the intake of dairy protein could increase postprandial satiety through changes in amino acid profiles.

Interestingly, the postprandial ghrelin $(25,26)$ and CCK $(26)$ concentrations have also been shown to be affected by the total protein content of the meal, since CCK secretion may be increased by duodenal protein and this CCK secretion could in turn affect ghrelin secretion (26). These hormones have been shown to affect satiety and food intake $(27,28)$. So it could be speculated that the source of protein could affect the CCK 
and ghrelin response (and satiety and food intake) as well, since different types of protein differ in bioavailability (19).

Finally, the addition of the amino acids leucine and phenylalanine to a carbohydrate and protein hydrolysate containing drink has been shown to cause large increases in the plasma insulin response $(29,30)$ and to increase postprandial glucose disposal in both diabetics and healthy subjects (29). So an increased consumption of these amino acids (both present in relatively high concentrations in dairy products) could also affect postprandial glucose metabolism.

An already existing investigation about the effects of dairy and calcium intake on postprandial fat and energy metabolism offered us the opportunity to study the hypothesis that the protein source of a meal could induce changes in postprandial amino acid profiles and that possible differences in these profiles may affect markers of satiety and glucose metabolism.

\section{Subjects and methods}

\section{Subjects}

Eighteen male subjects were recruited by advertising at Universities in Copenhagen and the internet. Subjects had to be healthy, between 18 and 50 years old, and moderately overweight. The exclusion criteria were lactose intolerance, milk allergy, diabetes, hypertension, hyperlipidemia, chronic infectious disease (HIV or hepatitis), smoking, elite athletes, regular use of medication and use of dietary supplements. Subject who had donated blood within the last six months before the study or subjects with a hemoglobin $<130 \mathrm{~g} / \mathrm{L}$ were excluded, and the subjects were instructed not to donate blood during the study period. After having received verbal and written information about the study, all subjects gave written consent. The study was carried out at the Department of Human Nutrition, Faculty of Life Sciences, University of Copenhagen, and was approved by the Municipal Ethical Committee of Copenhagen and Frederiksberg in accordance with the Helsinki-II declaration (KF 01-144/02). Subjects received $3000 \mathrm{Dkr}$. ( $\sim 500 \$)$ on completion of all tests. Characteristics of the subjects are presented in Table 1.

Table 1 Characteristics of the subjects

\begin{tabular}{lc}
\hline & Subjects \\
\hline $\mathrm{N}^{1}$ & 18 \\
Age (years) & $25.7 \pm 1.2$ \\
Height (cm) & $184 \pm 2$ \\
Weight $(\mathrm{kg})$ & $91.4 \pm 1.2$ \\
BMI $(\mathrm{kg} / \mathrm{m} 2)$ & $27.1 \pm 0.5$ \\
Habitual intake & \\
Energy (kJ/day) & $12985 \pm 624$ \\
Protein (E\%) & $15.4 \pm 0.5$ \\
Carbohydrate & $51.2 \pm 1.4$ \\
(E\%) & $26.7 \pm 1.1$ \\
Fat (E\%) & $6.6 \pm 1.5$ \\
Alcohol (E\%) & $1380 \pm 104$ \\
Calcium (mg/day) & \\
\hline
\end{tabular}

${ }^{1}$ Mean \pm SEM; ${ }^{2}$ Habitual intake was assessed by a three-day, weighed food record. E\%: \% of the energy. 


\section{Experimental design}

This study was originally designed to investigate the relation between calcium, dairy and postprandial lipid metabolism. But it was a good opportunity to study the effects of postprandial amino acid profiles on markers of satiety under strictly controlled conditions. The original study had a randomized, crossover design, in which five different isocaloric meals were examined. Since the protein sources of four of these five meals were similar, we investigated the differences between the two meals with a difference in protein content but similar calcium content (i.e. the DAIRY meal and the SOY meal). We choose these two meals since they were the only two meals with similar calcium and macronutrient content but a different protein content. The subjects were randomized to the sequence of the test meals. Between each meal test there was a washout period of at least 3 weeks.

Each meal test lasted for 8.5 hours. The subjects were instructed not to eat or drink dairy products or food items rich in fat such as potato crisps and chocolate the last two days before each meal test or drink alcohol or perform hard physical activities the last day before each meal test. The evening prior to the test the subjects consumed a standardized meal, which was supplied to them, consisting of a pasta dish, orange juice and biscuits (4MJ; 17.6 percent of energy (E\%) from protein, $22.1 \mathrm{E} \%$ fat, $60.3 \mathrm{E} \%$ carbohydrate). After consuming this meal (before 8 p.m.) the subjects had to fast. However, they were supplied with $500 \mathrm{ml}$ water of which they were instructed to consume $250 \mathrm{ml}$ before they went to bed and $250 \mathrm{ml}$ in the morning before they left the house. On the morning of the tests the subjects arrived at the department by car, bus, train or walking slowly (i.e. a non-strenuous means of transportation). On arrival they were weighed wearing only underwear and after emptying their bladder. Their weight was measured in kilograms to the nearest decimal with a Lindetronic 8000 scale (Copenhagen, Denmark). Then a Venflon catheter was inserted in an antecubital arm vein. After 20 minutes of rest a fasting blood sample was taken and the subject's appetite sensation was rated with visual analogue scales (VAS), after which the test meal was served. The subjects were instructed to consume the meal in exactly 15 minutes. Afterwards they completed a questionnaire on the palatability of the meal. During the next seven hours blood samples were taken at 15, 30, 60, 90, 120, 180, 300 and $420 \mathrm{~min}$ after intake of the meal was started and appetite sensation was rated every $30 \mathrm{~min}$. During the day the subjects could read, walk around at the institute, listen to radio or watch $\mathrm{TV} /$ video. On each test day one to three subjects were tested. They could talk with each other as long as the conversation did not involve food, appetite and related issues. They were not allowed to eat or drink during the day except for 2 glasses of water $(250 \mathrm{ml}$ each), which were served at 180 and $300 \mathrm{~min}$ (after the blood samples were drawn). At the end of the day, after the last blood sample was taken, an ad libitum meal consisting of a pasta salad (15E\% protein, $30 \mathrm{E} \%$ fat, $55 \mathrm{E} \%$ carbohydrate) and water was served and food intake was registered and energy intake calculated. The subjects were instructed to eat until 'comfortable satisfaction'. The subjects' water intake was registered at the first test day and this intake was repeated on the following test days. Afterwards they filled in a questionnaire on palatability of the meal and their appetite sensation was rated.

\section{Test meals}

In this study, the effects of two isocaloric test meals were examined (Table 2). They were given to the subjects in a randomized order. One test meal contained dairy proteins 
as the main protein source (DAIRY). The other meal contained soy proteins as the main protein source (SOY).

The test meals consisted of a bun, dairy products, chocolate and water (Table 2). It was assured that all test meals consisted of the same amount of bun, yoghurt and liquid. The protein content of the meals was varied by using a different type of protein powder for preparing the bun (i.e. soy or casein protein powder). The contents of calcium and energy were analyzed (see below for methods). The test meals had the same composition of macronutrients: $15 \mathrm{E} \%$ protein, $39 \mathrm{E} \%$ fat and $46 \mathrm{E} \%$ carbohydrate. In addition all test meals contained the same amount of lactose, which was adjusted by adding lactose powder to the bun and/or drink.

Table 2. The nutrient composition of the two test meals.

\begin{tabular}{lcc}
\hline & DAIRY & SOY \\
\hline Energy $(\mathrm{kJ})^{1}$ & 4464 & 4543 \\
Protein $\left(\mathrm{E}^{2}{ }^{2}\right)$ & 14.9 & 15.1 \\
Fat $(\mathrm{E} \%)$ & 39.3 & 39.1 \\
Carbohydrate & 45.9 & 45.9 \\
$(\mathrm{E} \%)$ & & \\
Calcium $(\mathrm{mg})$ & 68 & 102 \\
\hline
\end{tabular}

${ }^{1}$ Measured values (see the text for description of the method); ${ }^{2} \mathrm{E} \%$ : \% of the total energy content

The test meals were prepared at the Department from normal Danish food items according to each subjects' individual energy requirement adjusted to the nearest $1 \mathrm{MJ}$. Each test meal contained $50 \%$ of the subjects' daily energy requirement. The subjects' energy requirements were determined by the following formula based on a metaanalysis of the 24-h calorimetry studies at the department (Buemann 2003, unpublished):

24-h EE $(\mathrm{kJ} /$ day $)=1780.6+101.2 * \mathrm{FFM}+32.2 * \mathrm{FM}+212.4 * \mathrm{SPA}+4.03 * \mathrm{DE}-4.17 *$ age

Spontaneous physical activity (SPA) was $5.8 \%$ for men and duration of exercise (DE) was set to 30 min (31). Body composition was measured at baseline by bioelectrical impedance method and fat-free mass (FFM) and fat mass (FM) were calculated.

The subjects' habitual diet was assessed with a three-day, weighed food record (two weekdays and a Saturday). The subjects were given both verbal and written instructions on how to fill out the food record, and digital scales were supplied. The computer database Dankost 3000 (Dankost 3000, National Food Agency of Denmark, Søborg, Denmark) was used for the calculations of the energy and nutrient composition of the diets (32). The subjects' habitual intakes are shown in Table 1.

\section{Calcium and energy content of the test meals}

A dish of each meal was freeze-dried and homogenized. Gross energy content was obtained using a bomb calorimeter (Ika-calorimeter system C4000 Heitersheim, Germany). The analyses were performed in duplicate. Before calcium content was measured the samples were lyophilized and microwave digested (MES-1000, CEM Corporation, Matthews, North Carolina, USA) with HNO3 65\%, suprapur (Merck, Darmstadt, Germany), and $\mathrm{H} 2 \mathrm{O} 2$ 30\%, suprapur (Merck, Darmstadt, Germany). Calcium was measured by atomic absorption spectroscopy SpectraAA-200 VARIAN (Varian Techtron Pty. Limited, Victoria, Australia) after dilution with lanthaniumoxide solution (Merck, Darmstadt, Germany). Standards were prepared from a $1000 \mathrm{mg} / \mathrm{L} \mathrm{Ca}$ standard (Tritisol ${ }^{\circledR}$, Merck, Darmstadt, Germany) by dilution with lanthaniumoxide solution. A reference diet (Standard Reference Material 1548a, Typical Diet, National 
Institute of Standards and Technology, Gaithersburg, MD, USA) was analyzed in the same run. The percent of recovery of calcium in the reference diet was $89 \%$. The calcium content in the samples was adjusted to concentrations corresponding to $100 \%$ recovery.

\section{Visual analogue scale}

Visual analogue scales, $100 \mathrm{~mm}$ in length with words anchored at each end, expressing the most positive and the most negative rating, were used to measure appetite sensation (hunger, satiation, fullness, prospective food consumption, thirst, comfort, and desire to eat something sweet, salty, fatty or meat/fish) and palatability of the test meal and the ad libitum meal. These questionnaires have been described in more detail previously (33). The questions were made as small booklets showing one question at the time. Subjects were instructed not to compare their ratings with each other and could not refer to their previous rating when filling in the VAS.

\section{Biochemical analyses}

Venous blood samples were drawn at baseline, 15, 30, 60, 90, 120, 180, 300 and 420 minutes after start of the test meal. Blood samples for plasma analyses were collected in tubes containing EDTA and placed on ice immediately. Blood samples for serum analyses were collected in serum tubes and kept at room temperature for 30 minutes to coagulate. All samples were centrifuged at $2800 \mathrm{~g}$ for 15 minutes at $4{ }^{\circ} \mathrm{C}$ and stored at $20^{\circ} \mathrm{C}$ until later analysis (exceptions are described in the following).

\section{Amino acids}

Plasma $(200 \mu \mathrm{L})$ for amino acid analysis was deproteinized on ice with $50 \%(\mathrm{w} / \mathrm{v}) 5$ sulfosalysic acid, vortex mixed and the clear supernatant obtained after centrifugation was stored at $-80 \mathrm{C}$ until further analysis. Amino acids were analyzed on an automated dedicated amino acid analyzer (LC5001, Biotronik, Munchen, Germany) using a cationic exchange resin (type BTC 2710, Biotronik), a grade of lithiumcitrate elution buffers and post-column derivatisation with ninhydrin, all according to working recipes of the suppliers. The same procedures were performed to determine the amino acid composition of the protein hydrolysates except for that a different amino acid analyzer was used (Pharmacia LKB technology, Roosendaal, The Netherlands). The calibration curves of the amino acids were obtained using commercial amino acid mixtures. Norvaline was used as internal standard and added to all plasma samples prior to deproteinisation.

\section{Plasma concentrations of glucose, CCK, ghrelin and insulin}

Plasma concentrations of glucose, $\mathrm{CCK}$ and ghrelin were measured in blood samples drawn at baseline, 15, 30, 60, 90 (only glucose), 120, 180, 300 (except glucose) and 420 minutes after the start of the test meal.

Glucose was measured by an enzymatic endpoint method (Hexokinase) (Gluco-quant ${ }^{\circledR}$ Glucose/HK, Roche Diagnostics, Basel, Switzerland) using a Cobras Mira plus (Roche, Basel, Switzerland). CVintra\% was 1.1 and CVinter\% was 1.3.

CCK concentration in plasma was measured by radioimmunoassay using an antiserum (code no. 92128) that binds the circulating CCK with equimolar potency without crossreactivity with any gastrins. Details of the assay and its reliability parameters are described elsewhere (30). 
Plasma ghrelin concentration was determined using a radioimmunoassay kit (Cat. \#GHRT-89k, Linco Research, St. Charles, Missouri), which measures total ghrelin (intact and desoctanoylated ghrelin). The sensitivity was $100 \mathrm{pg} / \mathrm{ml}$, and CVintra $\%$ was below $10 \%$. Quality controls were always within acceptable limits.

Serum concentrations of insulin were measured in blood samples drawn at baseline, 30, $60,90,120,180$ and 420 minutes after the start of the test meal. Insulin was determined by solid phase, two-site chemiluminescent immunometric assay (Immulite $\AA /$ immuliter 1000 insulin. DPC, Diagnostic products Corporation, Los Angeles, USA) using an Immulite 1000 analyzer (Diagnostic products Corporation, Los Angeles, USA). The CVintra\% and CVinter\% was 2.5 and 4.9 respectively.

\section{Statistical analyses and calculations}

All data are expressed as mean \pm SEM. The plasma response of the amino acids, metabolites and hormones described in this investigation was estimated by calculating the area under the curve (AUC), during the seven hour-period after the ingestion of the test meal, with a correction for the baseline values. Possible significant differences in the plasma response of the different amino acids induced by the test meals were calculated by using an ANOVA analysis for repeated measures. We also calculated the Pearson's correlation coefficients between the AUC responses of the LNAAs, BCAAs, the TRP/LNAA-ratio, the TYR-LNAA-ratio, the plasma parameters (i.e. CCK, ghrelin, glucose and insulin), all of the results of the VAS measurements and food intake at the ad libitum meal. Furthermore, a step-wise linear regression analysis was performed to investigate the effects of the plasma response of different groups of amino acids on markers of satiety and of the amino acid concentration on plasma insulin and glucose. Statistical difference was set at $p<0.05$. Corrections for multiple testing were performed where applicable. SPSS for Mac OS X version 11 (Chicago, IL) was used for the statistical analysis.

\section{Results}

The plasma concentration of most of the amino acids increased postprandially, as indicated by a positive area under the curve (table 3). A significantly higher AUC was observed in the dairy condition during the seven hours of postprandial measurements for the following amino acids: $\alpha$-aminobutyrate $(p<0.05)$, tyrosine $(p<0.0001)$, valine $(p<0.01)$, methionine $(p<0.01)$, ileonine $(p<0.01)$, leucine $(p<0.05)$, and for the LNAAs $(\mathrm{p}<0.0001)$ and BCAAs $(\mathrm{p}<0.0001)$. 
Table 3 The AUC of the plasma amino acids (mmol/L*420min)

\begin{tabular}{|c|c|c|c|c|}
\hline & DAIRY & $\mathrm{TTP}^{4}$ & SOY & $\mathrm{TTP}^{4}$ \\
\hline GLU & $2071 \pm 1322$ & 60 & $77 \pm 1823$ & 120 \\
\hline ASN & $3476 \pm 488$ & 60 & $5367 \pm 1111$ & 120 \\
\hline SER & $15984 \pm 5737$ & 60 & $6893 \pm 2381$ & 120 \\
\hline GLN & $10759 \pm 3485$ & 60 & $4747 \pm 3494$ & 120 \\
\hline HIS & $3301 \pm 2675$ & 60 & $-2574 \pm 3838$ & 60 \\
\hline GLY & $6980 \pm 2229$ & 60 & $7684 \pm 3393$ & 120 \\
\hline THR & $8999 \pm 3068$ & 60 & $3610 \pm 2423$ & 120 \\
\hline CIT & $1589 \pm 1068$ & 60 & $1890 \pm 1493$ & 120 \\
\hline ARG & $20509 \pm 5431$ & 60 & $11427 \pm 3670$ & 60 \\
\hline ALA & $23528 \pm 5856$ & 60 & $23804 \pm 6231$ & 60 \\
\hline TAU & $-270 \pm 413$ & 60 & $-845 \pm 459$ & 60 \\
\hline $\mathrm{AAB}$ & $4992 \pm 1609^{1}$ & 60 & $1028 \pm 813$ & 60 \\
\hline TYR & $16640 \pm 2255^{3}$ & 60 & $4867 \pm 2036$ & 120 \\
\hline VAL & $19037 \pm 3321^{2}$ & 60 & $6961 \pm 2577$ & 120 \\
\hline MET & $7541 \pm 1296^{2}$ & 60 & $2057 \pm 1501$ & 120 \\
\hline ILE & $11341 \pm 1128^{2}$ & 60 & $6279 \pm 1321$ & 120 \\
\hline PHE & $5579 \pm 782$ & 60 & $4170 \pm 945$ & 120 \\
\hline TRP & $9288 \pm 2459$ & 60 & $3667 \pm 1986$ & 120 \\
\hline LEU & $15001 \pm 2781^{1}$ & 60 & $6445 \pm 1517$ & 120 \\
\hline ORN & $656 \pm 2425$ & 60 & $358 \pm 1651$ & 120 \\
\hline LNAA & $76887 \pm 6379^{3}$ & 60 & $32388 \pm 6486$ & 120 \\
\hline TRP/LNAA & $0.1473 \pm 0.0406$ & 60 & $0.1084 \pm 0.1236$ & 120 \\
\hline TYR/LNAA & $0.2441 \pm 0.0355$ & 60 & $0.6145 \pm 0.5152$ & 120 \\
\hline BCAA & $39666 \pm 2995^{3}$ & 60 & $16906 \pm 4124$ & 120 \\
\hline
\end{tabular}

${ }^{1}$ Significantly different from SOY, $\mathrm{p}<0.05 ;{ }^{2}$ Significantly different from $\mathrm{SOY}, \mathrm{p}<0.01 ;{ }^{3}$ Significantly different from SOY, $\mathrm{p}<0.0001 ;{ }^{4} \mathrm{TTP}=\mathrm{Time}$ To Peak, the time point at which the maximal concentration of the amino acids was reached.

The AUCs for the plasma metabolites and hormones and of the hunger ratings are shown in table 4 and 5. The responses of the plasma parameters and of the hunger ratings followed the expected pattern and we observed no significant differences between the conditions. No significant differences in energy intake were observed at the ad libitum test meal (data not shown).

Table 4 AUC of glucose $(\mathrm{mmol} / 1 * 420 \mathrm{~min})$, insulin $(\mathrm{pmol} / 1 * 420 \mathrm{~min})$, ghrelin $(\mathrm{pg} / \mathrm{ml} * 420 \mathrm{~min})$ and CCK (pmol/1*420min)

\begin{tabular}{lcccc}
\hline & DAIRY & TTP/TTN & SOY & TTP/TTN $^{1}$ \\
\hline Glucose & $121 \pm 59$ & 30 & $117 \pm 53$ & 30 \\
Insulin & $86390 \pm 13494$ & 30 & $79160 \pm 11607$ & 30 \\
Ghrelin & $-42869 \pm 7115$ & 120 & $-45050 \pm 8316$ & 120 \\
CCK & $435 \pm 50$ & 120 & $480 \pm 37$ & 120 \\
\hline
\end{tabular}

None of these differences were statistically significant; ${ }^{1} \mathrm{TTP}=\mathrm{Time}$ To Peak: the time point at which the maximal concentration of the parameter was reached (for glucose, insulin and CCK); TTN=Time To Nadir: the time point at which the minimal concentration of the parameter was reached (for ghrelin).

We estimated the time point at which the amino acids reached their maximal concentration. In the dairy condition, all amino acids reached their maximal concentration 60 minutes after the ingestion of the test meal. In the soy condition, the concentration of most amino acids peaked after 120 minutes (table 3 ). 
Table 5 AUC during the 420 minutes postprandially of the VAS questionnaires

\begin{tabular}{lcc}
\hline & DAIRY & SOY \\
\hline Satiation & $9785 \pm 1183$ & $12264 \pm 1918$ \\
Hunger & $-9759 \pm 1210$ & $-10883 \pm 1591$ \\
Fullness & $10720 \pm 1495$ & $13138 \pm 1991$ \\
Thirst & $-4448 \pm 1705$ & $-2400 \pm 1685$ \\
Comfort & $515 \pm 968$ & $-1673 \pm 1323$ \\
Prospective food consumption & $-9945 \pm 1368$ & $-9098 \pm 1559$ \\
Desire to eat something fatty & $4867 \pm 1582$ & $5134 \pm 1900$ \\
Desire to eat something salty & $2755 \pm 1480$ & $2065 \pm 1783$ \\
Desire to eat meat/fish & $-130 \pm 1343$ & $2030 \pm 1765$ \\
Desire to eat something sweet & $3588 \pm 1486$ & $4387 \pm 1351$ \\
\hline
\end{tabular}

None of these differences were statistically significant

The timing of the maximal concentration was also estimated for glucose, insulin and CCK. Glucose and insulin attained a maximal value after 30 minutes and CCK after 120 minutes. The ghrelin concentrations were the lowest after 120 minutes (table 4).

We calculated Pearson's correlation coefficients between the AUC responses of the LNAAs, BCAAs, the TRP/LNAA-ratio, the TYR-LNAA-ratio, the plasma parameters (i.e. CCK, ghrelin, glucose and insulin), all of the results of the VAS measurements and food intake at the ad libitum meal. The correlation coefficient between ghrelin and TRP/LNAA-ratio was $0.34(\mathrm{p}=0.045)$. Furthermore, a significant correlation was observed between the TYR/LNAA-ratio and the CCK response $(\mathrm{r}=0.36, \mathrm{p}=0.031)$. None of the other correlations were statistically significant.

Finally, we have also performed a stepwise regression analysis to investigate if the plasma response of the satiety markers, of food intake and of the VAS scores could be predicted by the response of the amino acids. The TRP/LNAA-ratio was a significant predictor of the ghrelin response $(p<0.05)$. And finally, the TYR/LNAA-ratio was a significant predictor of the CCK response $(\mathrm{p}<0.05)$. None of the other regression coefficients were statistically significant.

We have also performed the same analyses for all of the five meals mentioned above (also see test meals) and the outcomes of the analyses were similar.

\section{Discussion}

In this investigation, we studied the effects of two meals with different sources of protein on postprandial plasma amino acid profiles, on indicators of satiety and on the postprandial concentrations of insulin and glucose. We observed significant differences for the postprandial response of individual amino acids. The majority of these amino acids were either LNAAs (tyrosine, leucine, valine, methionine) and/or BCAAs (leucine, valine). We also observed a significantly higher total BCAA and LNAA response after the DAIRY meal when compared to the SOY meal. However, these differences in postprandial amino acid metabolism did not cause differences in any of the plasma parameters, the VAS measurements or in food intake at a subsequent meal, so the postprandial differences in amino acid metabolism did not affect markers of satiety. Finally, we identified significant correlations between the ratios of tryptophan and tyrosine to the LNAAs and the plasma values of ghrelin and CCK. 
According to some previous investigations, a high consumption of dairy products could have beneficial effects on postprandial energy metabolism and satiety. In a number of investigations, an increased postprandial fat oxidation was observed in response to meals with a high dairy content (34-37). An explanation for this increased fat oxidation could be that the high concentration of BCAAs in whey and casein protein has favorable effects on postprandial energy metabolism, for example through an increased insulin sensitivity of the muscular tissue and an increased protein synthesis (18-20). In line with this, an increase of the recommended intake of leucine has also been suggested by Layman because of the potential role in the preservation of lean mass during energy restriction (38). Leucine is a BCAA, which is present in relatively high amounts in dairy and we indeed observed an increased concentration after the DAIRY meal.

It had been shown that dairy and animal protein are more satiating than protein from vegetable sources (15-17) and therefore, we had hypothesized that a meal with high dairy content could increase postprandial satiety compared to a meal containing vegetable protein but we did not see any differences in satiety. But this could be caused by differences in design since these studies used a preload meal containing only protein (17), in the other investigations lean subjects were studied (16) or satiety was assessed during a shorter period after the meal (15). These differences in design could explain the different results. In line with our results, no effects of the type of protein were observed in another investigation on 24-hour energy intake, energy metabolism and satiety (39).

We did find a significant positive correlation between the response of the TRP/LNAAratio and the plasma ghrelin response. It has been suggested that a decrease in this ratio could result in a decreased availability of tryptophan to the brain. This could impair the formation of serotonin, which plays a role in satiety $(21,22)$. The TRP/LNAA-ratio has been shown to be related to food intake $(23,24)$. This is the first report of a possible relation between the satiety hormone ghrelin and the TRP/LNAA-ratio, although we could not identify a mechanism behind this relation, but it has been observed previously (24).

In line with this, we also observed that the response of the TYR/LNAA-ratio was correlated with the plasma CCK response. Tyrosine is necessary for the formation of catecholamines, that play a role in satiety $(21,22)$ and similar to the TRP/LNAA-ratio, decreases in this ratio may indicate a decreased availability of tyrosine to the brain. Like the correlation between TRP/LNAA and ghrelin, this is the first report of a possible relation between the TYR/LNAA-ratio and the plasma CCK response. The experimental design of this study did not allow us to explore possible mechanisms behind this observation and since the TYR/LNAA-ratio and plasma CCK concentration both increase after a meal $(24,25)$, this could be a mere correlation.

The fact that the TRP/LNAA- and TYR/LNAA-ratios peaked before or at the same time that the $\mathrm{CCK}$ and ghrelin concentrations showed the maximal difference from baseline supports the possibility that there is a relation between these variables.

Finally, we observed in a step-wise linear regression analysis that the TRP/LNAA-ratio was a significant predictor of the plasma ghrelin response and that the TYR/LNAA-ratio was a significant predictor of the CCK response.

It should be noted that this study was originally designed to study the effects of calcium and dairy intake on postprandial fat metabolism, appetite and subsequent energy intake. Therefore, we were not able to further elucidate possible mechanisms behind the observed significant correlations between the amino acids and the satiety hormones.

One of the limits of this study is that it was not powered to investigate the effects of meals with a different protein content on subjective markers of satiety, but to study the 


\section{Chapter 8}

effects on fat and energy metabolism and blood lipid profiles, which are measurements with a smaller measurement error, requiring a smaller number of subjects to detect a significant difference. This lack of power may have prevented us from detecting any significant differences.

Summarizing the results of this investigation, it can be stated that although we observed some significant differences in postprandial amino acid metabolism, we did not observe any differences in markers of postprandial satiety in response to two meals with a different type of protein. The overall BCAA and LNAA responses were significantly higher in the DAIRY condition, in comparison to the SOY condition, which could increase postprandial energy expenditure and preserve lean mass during energy restriction. Finally, we observed that the postprandial ghrelin and CCK responses were associated with the TRP/LNAA-ratio and the TYR/LNAA-ratio, respectively. However, the design of the present investigation did not allow us to study the mechanism behind these observations. 


\section{References}

1. Anderwald C, Roden M. Adipotoxicity and the insulin resistance syndrome. Pediatr Endocrinol Rev 2004;1:310-9.

2. Lakka HM, Laaksonen DE, Lakka TA, et al. The metabolic syndrome and total and cardiovascular disease mortality in middle-aged men. Jama 2002;288:2709-16.

3. Sullivan PW, Morrato EH, Ghushchyan V, Wyatt HR, Hill JO. Obesity, inactivity, and the prevalence of diabetes and diabetes-related cardiovascular comorbidities in the U.S., 2000-2002. Diabetes Care 2005;28:1599-603.

4. McCarron DA. Dietary calcium as an antihypertensive agent. Nutr Rev 1984;42:223-5.

5. Lin YC, Lyle RM, McCabe LD, McCabe GP, Weaver CM, Teegarden D. Dairy calcium is related to changes in body composition during a two-year exercise intervention in young women. J Am Coll Nutr 2000;19:754-60.

6. Shapses SA, Heshka S, Heymsfield SB. Effect of calcium supplementation on weight and fat loss in women. J Clin Endocrinol Metab 2004;89:632-7.

7. Pereira MA, Jacobs DR, Jr., Van Horn L, Slattery ML, Kartashov AI, Ludwig DS. Dairy consumption, obesity, and the insulin resistance syndrome in young adults: the CARDIA Study. Jama 2002;287:20819.

8. Jacqmain M, Doucet E, Despres JP, Bouchard C, Tremblay A. Calcium intake, body composition, and lipoprotein-lipid concentrations in adults. Am J Clin Nutr 2003;77:1448-52.

9. Davies KM, Heaney RP, Recker RR, et al. Calcium intake and body weight. J Clin Endocrinol Metab 2000;85:4635-8.

10. Atkin LM, Davies PS. Diet composition and body composition in preschool children. Am J Clin Nutr 2000;72:15-21.

11. Boon N, Hul GB, Viguerie N, Sicard A, Langin D, Saris WH. Effects of 3 diets with various calcium contents on 24-h energy expenditure, fat oxidation, and adipose tissue message RNA expression of lipid metabolism-related proteins. Am J Clin Nutr 2005;82:1244-52.

12. Jacobsen R, Lorenzen JK, Toubro S, Krog-Mikkelsen I, Astrup A. Effect of short-term high dietary calcium intake on 24-h energy expenditure, fat oxidation, and fecal fat excretion. Int J Obes Relat Metab Disord 2005;29:292-301.

13. Shahkhalili Y, Murset C, Meirim I, et al. Calcium supplementation of chocolate: effect on cocoa butter digestibility and blood lipids in humans. Am J Clin Nutr 2001;73:246-52.

14. Welberg JW, Monkelbaan JF, de Vries EG, et al. Effects of supplemental dietary calcium on quantitative and qualitative fecal fat excretion in man. Ann Nutr Metab 1994;38:185-91.

15. Turnbull WH, Walton J, Leeds AR. Acute effects of mycoprotein on subsequent energy intake and appetite variables. Am J Clin Nutr 1993;58:507-12.

16. Uhe AM, Collier GR, O'Dea K. A comparison of the effects of beef, chicken and fish protein on satiety and amino acid profiles in lean male subjects. J Nutr 1992;122:467-72.

17. Anderson GH, Tecimer SN, Shah D, Zafar TA. Protein source, quantity, and time of consumption determine the effect of proteins on short-term food intake in young men. J Nutr 2004;134:3011-5.

18. Ha E, Zemel MB. Functional properties of whey, whey components, and essential amino acids: mechanisms underlying health benefits for active people (review). J Nutr Biochem 2003;14:251-8.

19. Fouillet H, Mariotti F, Gaudichon C, Bos C, Tome D. Peripheral and splanchnic metabolism of dietary nitrogen are differently affected by the protein source in humans as assessed by compartmental modeling. J Nutr 2002;132:125-33.

20. Garlick PJ, Grant I. Amino acid infusion increases the sensitivity of muscle protein synthesis in vivo to insulin. Effect of branched-chain amino acids. Biochem J 1988;254:579-84.

21. Uhe AM, Szmukler GI, Collier GR, Hansky J, O'Dea K, Young GP. Potential regulators of feeding behavior in anorexia nervosa. Am J Clin Nutr 1992;55:28-32.

22. Schweiger U, Warnhoff M, Pahl J, Pirke KM. Effects of carbohydrate and protein meals on plasma large neutral amino acids, glucose, and insulin plasma levels of anorectic patients. Metabolism 1986;35:938-43.

23. Attia E, Wolk S, Cooper T, Glasofer D, Walsh BT. Plasma tryptophan during weight restoration in patients with anorexia nervosa. Biol Psychiatry 2005;57:674-8.

24. Moller SE. Carbohydrate/protein selection in a single meal correlated with plasma tryptophan and tyrosine ratios to neutral amino acids in fasting individuals. Physiol Behav 1986;38:175-83.

25. Blom WA, Lluch A, Stafleu A, et al. Effect of a high-protein breakfast on the postprandial ghrelin response. Am J Clin Nutr 2006;83:211-20. 
26. Bowen J, Noakes M, Trenerry C, Clifton PM. Energy intake, ghrelin and CCK after different carbohydrate and protein preloads in overweight men. J Clin Endocrinol Metab 2006.

27. Wren AM, Seal LJ, Cohen MA, et al. Ghrelin enhances appetite and increases food intake in humans. J Clin Endocrinol Metab 2001;86:5992.

28. Hayes MR, Covasa M. CCK and 5-HT act synergistically to suppress food intake through simultaneous activation of CCK-1 and 5-HT3 receptors. Peptides 2005;26:2322-30.

29. Manders RJ, Wagenmakers AJ, Koopman R, et al. Co-ingestion of a protein hydrolysate and amino acid mixture with carbohydrate improves plasma glucose disposal in patients with type 2 diabetes. Am J Clin Nutr 2005;82:76-83.

30. van Loon LJ, Saris WH, Verhagen H, Wagenmakers AJ. Plasma insulin responses after ingestion of different amino acid or protein mixtures with carbohydrate. Am J Clin Nutr 2000;72:96-105.

31. Klausen B, Toubro S, Astrup A. Age and sex effects on energy expenditure. Am J Clin Nutr 1997;65:895-907.

32. Møller A, Saxholt, E., Christensen, A.T., Hartkopp, H.B., Hess Ygil, K. Danish Food Composition Databank, revision 6.0. Food Informatics, Institute of Food Safety and Nutrition, Danish Institute for Food and Veterinary Research, 2005.

33. Flint A, Raben A, Blundell JE, Astrup A. Reproducibility, power and validity of visual analogue scales in assessment of appetite sensations in single test meal studies. Int $\mathrm{J}$ Obes Relat Metab Disord 2000;24:38-48.

34. Cummings NK, Soares MJ, James AP, Ping-Delfos WC. Comparison of dairy and non-dairy sources of calcium on thermogenesis and substrate oxidation in humans. Asia Pac J Clin Nutr 2004;13:S87.

35. Melanson EL, Donahoo WT, Dong F, Ida T, Zemel MB. Effect of low- and high-calcium dairy-based diets on macronutrient oxidation in humans. Obes Res 2005;13:2102-12.

36. Ping-Delfos WC, Soares MJ, Cummings NK. Acute suppression of spontaneous food intake following dairy calcium and vitamin D. Asia Pac J Clin Nutr 2004;13:S82.

37. Soares MJ, Ping-Delfos WC, James AP, Cummings NK. Dairy calcium and vitamin D stimulate postprandial thermogenesis: effect of sequential meals. Asia Pac J Clin Nutr 2004;13:S56.

38. Layman DK. Protein quantity and quality at levels above the RDA improves adult weight loss. J Am Coll Nutr 2004;23:631S-636S.

39. Lang V, Bellisle F, Oppert JM, et al. Satiating effect of proteins in healthy subjects: a comparison of egg albumin, casein, gelatin, soy protein, pea protein, and wheat gluten. Am J Clin Nutr 1998;67:1197204. 


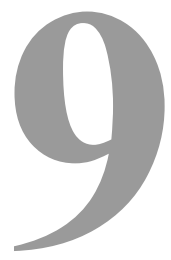

General discussion 


\section{Introduction}

In this thesis, we have presented a series of investigations in which we looked into possible mechanisms through which an increased dairy intake can have beneficial effects on body weight. In this discussion, the results of all of these investigations are put together and they are discussed in the light of results from other studies. We will also evaluate the strengths and weaknesses of our study designs. Finally we will sum up the implications of our results and give directions for future research.

Initially, the main focus of this PhD-project was to study the effects of dietary (dairy) calcium intake on fat and energy metabolism. After the publication of some crosssectional studies in which an inverse association between calcium and/or dairy intake and body weight was observed in some North-American populations (1-3), the group of Zemel published a hypothesis to explain this relation (4). This hypothesis states that when dietary calcium intake is increased, this will rapidly decrease the serum concentration of $1,25-\mathrm{OH}_{2} \mathrm{D}_{3}$ (calcitriol): a steroid hormone and metabolite of vitamin D. The decreased concentration of calcitriol will decrease the intracellular calcium concentration $\left(\left[\mathrm{Ca}^{2+}\right]_{i}\right)$. This will in turn lead to a decrease in the transcription of fatty acid synthase (FAS) mRNA and an increase in lipolysis. The latter could be mediated through a decreased activity of phosphodiesterase $3 b$ (PDE 3b), which will increase the concentration of cyclic adenosine monophosphate (cAMP) and in this way increase lipolysis. A low rate of lipolysis is considered a prerequisite for becoming obese (5). Furthermore, the decreased serum calcitriol concentration could also have a stimulating effect on the mRNA expression of uncoupling protein 2 (UCP2), which has been shown to be correlated with the basal metabolic rate (BMR) (6). So via these metabolic pathways, an increase in the intake of calcium could have beneficial effects on body weight regulation through changes in the calcitriol metabolism.

\section{Observational studies}

Before we started to investigate the hypothesis that is described above, we wanted to test if the association between calcium intake and body composition that was observed in North American observational studies could also be observed in the Netherlands. In Europe in general but in the Netherlands in particular dietary calcium intake is much higher than in the US (7). Therefore, we analyzed food intake and body composition data from the Amsterdam Growth and Health Longitudinal Study (AGAHLS). We concluded that the association between calcium intake and body composition was not as strong as in North American populations but we did find a threshold for the effects of calcium intake on body composition at $800 \mathrm{mg}$ per day. The average calcium intake in this study was close to the Dutch average, so around $1000 \mathrm{mg}$ per day for women and around $1100 \mathrm{mg}$ per day for men and this could explain the difference in results between our study and previous ones from the US, because calcium may have been suboptimal in those investigations, i.e. around $700 \mathrm{mg}$ per day. We also observed in this investigation that calcium intake had a relatively low tracking coefficient. This means that calcium intake at the earlier measurements was not a very good predictor of calcium intake at the later measurements. Although we had initially planned to correct 
for the confounding effects of a high protein intake secondary to a high dairy intake it turned out that this was not possible due to statistical constraints. A high protein intake which normally coincides with a high dairy and thus high calcium intake could have independent beneficial effects on body composition through effects on thermogenesis, satiety and preservation of lean mass during energy restriction (8-10). Therefore, we performed an additional analysis of the same dataset to look into the association between macronutrient intake and body composition. We observed that despite a positive association between fat intake and total energy intake and a negative association between protein intake and total energy intake in both genders and a negative association between carbohydrate intake and energy intake in men, there was no longitudinal association between the intake of any of the macronutrients and body composition. Furthermore, in a cross-sectional analysis, we did observe that subjects with a high body fat $\%$ at the age of 36 had a high protein intake at the ages of 33 and 36. This is in contrast with the relation between protein and total energy intake we observed in the same study and it is also in contrast with previous studies that have shown beneficial effects of protein consumption on body weight control. This could be due to the fact that we were not able to discern between different sources of protein (i.e. vegetable, animal or dairy protein). Furthermore, there was also a difference in the type of analysis (ordinal vs. categorical) and the method to determine body composition (skinfold measurements vs. DEXA) between the two analyses.

\section{The effects of dietary calcium intake on fat and energy metabolism}

Thereafter, we studied different aspects of the relation between calcium intake from dairy and non-dairy sources and body weight regulation in intervention trials. Firstly, we did a randomized clinical intervention trial about the effects of three diets with various calcium contents but with similar protein content on energy and fat metabolism. Although we found in that study that the differences in calcium intake induced differences in the serum calcitriol concentration after 7 days, we did not see any differences in energy expenditure or adipose tissue mRNA expression of proteins that are involved in fat and energy metabolic pathways. We did observe that a high dairy diet increased fat oxidation with 8 grams per day compared to a low dairy diet, but this difference was not statistically significant. Our power calculations were based on an observed difference in fat oxidation of 20 grams, so the sample size in this study was not large enough to pick up the small effects on energy metabolism.

Our findings are in contrast with the results of Melanson et al., who reported a significant negative correlation between acute calcium intake and 24-hour fat oxidation and fat oxidation during sleep and exercise. However, this study was not originally designed to study the effects of calcium intake on macronutrient oxidation (11). Therefore they performed an additional trial in which they found that calcium intake increased fat oxidation during an energy deficit but not during energy balance (12). In the hypocaloric condition, a high calcium/ high dairy diet increased 24-hour fat oxidation with 30 grams per day compared to a low calcium/ low dairy diet. Jacobsen et al. also did not find any effects of an increased calcium intake on 24-hour energy or fat metabolism (13). In all of these well-controlled studies, indirect calorimetry was performed using the metabolic chamber technology. So increasing calcium/dairy intake seems to increase fat oxidation during energy restriction but not during energy balance. 
In order to study the exact role of changes in the serum calcitriol concentration, we performed another intervention trial, in which we supplemented healthy volunteers with 2000 I.U. of cholecalciferol per day. Although the supplementation with cholecalciferol in combination with a low-calcium and low-dairy diet increased the serum calcitriol concentration after 5 and 7 days to about the same extent as the low calcium low dairy diets in the previous investigation, this did not lead to changes in fat oxidation, energy metabolism or mRNA expression of the same genes we studied in the previous investigation. So from these first two experimental human studies, we concluded that one crucial step in the Zemel hypothesis namely that changes in the serum concentration of calcitriol as a consequence of low calcium intake lead to changes in fat, energy metabolism and adipose tissue gene expression is not present in humans.

Reason to investigate as a logical next step the effects of molecular changes in $\left[\mathrm{Ca}^{2+}\right]$ using the microdialysis technology. We used the effects of hydralazine, an antihypertensive agent, with well-known effects on changes in the intracellular calcium concentration on lipolysis. Increases in lipolysis were observed in response to perfusion with the highest dose of hydralazine. In line with our results, increases in lipolysis had previously been observed in in vitro models (14-16) in response to decreases in $\left[\mathrm{Ca}^{2+}\right]_{\mathrm{I}}$. So we concluded that the last step of the Zemel hypothesis (i.e. decreasing adipocyte $\left[\mathrm{Ca}^{2+}\right]_{\mathrm{I}}$ increases lipolysis) might be present in humans in vivo.

Although the first experiments described in this thesis were focused mainly on studying the possible effects of calcium and dairy intake on fat and energy metabolism, we have also studied other potential mechanistic explanations for the observed relation between dairy intake and body composition.

\section{The impact of dietary calcium on fat absorption}

Increasing dietary calcium intake could decrease fat absorption through the formation of insoluble fatty acid soaps in the intestine, which would decrease the amount of energy from dietary fat that is absorbed from the gastro-intestinal tract. In theory this is a realistic metabolic pathway since the drug Tetra-lipstatine (Orlistat TM) a lipase inhibitor also decreases fat intake with up to $30 \%$ (17). In earlier studies, small but statistically significant effects on faecal fat excretion had been observed as a result of increasing dietary calcium intake $(18,19)$. However, in a more recent publication, Jacobsen et al. observed increases in fat excretion of up to 8.2 grams per day. This was when they compared two diets with normal protein content (with 15\% of energy from protein) and a high or a low calcium concentration (500 vs. $1800 \mathrm{mg} /$ day). In a high-protein condition (with 23 energy percent (EN\%) protein), they did not observe any effects. Therefore, we looked at the effects of four diets with various calcium contents on faecal fat and energy excretion. Although there was a trend towards a higher fat and energy excretion in our study, we did not observe any significant effects. A post hoc power calculation revealed that a minimum of 18 subjects would have been needed to attain statistical significance. The smaller fat binding effects of calcium (compared to previous studies) could be due to the relatively high protein content (20 EN\%) of the diets in our study, because it has been suggested that protein increases the intestinal absorption of calcium, thus decreasing the amount of calcium that is available for binding to fat (2023). We choose to use this high protein content because we wanted to be able to compare the effects of this study to our previous ones, in which we used a high protein 
diet to correct for the confounding effects of protein intake. Also, the study of Jacobsen was not published at the time we designed our protocol and started this study.

\section{The relation between the postprandial plasma amino acid response and markers of satiety}

Finally, we have also investigated the effects of meals with different concentrations of dairy protein on postprandial plasma responses of amino acids and the relation of these responses to markers of satiety. We did not see any effects of the different meals on satiety markers. However, we did note significantly higher concentrations of BCAAs and LNAAs after a dairy-based meal compared to a soy-based meal. Furthermore, we also observed significant correlations between the ratios of tyrosine and tryptophan to LNAAs and the satiety hormones CCK and ghrelin, respectively. The ratio of tyrosine to the LNAAs and the satiety hormone CCK were positively correlated, as were the ratio of tryptophan to the LNAAs and the satiety hormone ghreline. Tyrosine as well as tryptophan share a common transport mechanism for transport across the blood-brain barrier with the other LNAAs, so a change in the ratio of tyrosine and tryptophan to these LNAAs could change the transport of tyrosine and tryptophan to the central nervous system. Since tyrosine and tryptophan are precursors for the formation of noradrenalin and serotonin, respectively, this could have central effects on satiety because these neurotransmitters have been shown to be important in satiety $(24,25)$. In summary, the results from this last experiment could mean that when meals with a different protein composition change the postprandial response of LNAAs and BCAAs, that these different responses could induce differences in satiety. So according to these results, to induce a maximal satiety effect, a food product would have to generate a high tyrosine and tryptophan response, relative to the total LNAA response.

\section{Methodological considerations}

The strength of the two epidemiological investigations is that they were both conducted in a cohort of healthy young volunteers that is representative of the population in The Netherlands and other European countries. This is especially important because dairy intake in Europe is high and possibly already optimal for maintaining a healthy body weight. Furthermore, the longitudinal regression analysis we used in these studies uses all available data and gives valuable information about the effects of changes in food intake over time.

The strengths of the two dietary intervention studies are that they were well controlled and that we were able to correct for the confounding effects of an increased protein intake. Furthermore, food intake and physical activity were well controlled in these trials.

In the oral cholecalciferol supplementation trial, we used a unique approach to study the effects of changes in serum calcitriol on energy metabolism and mRNA expression in adipose tissue. In this trial, food intake and physical activity of the subjects were strictly controlled as well.

In the microdialysis study we investigated the effects of hydralazine perfusion on lipolysis in human adipose tissue, which allowed us to directly manipulate the 
intracellular calcium concentration in order to study the intracellular aspects of the Zemel hypothesis in vivo.

Finally, we have described the first study to look into the effects of changes in plasma amino acid response as a result of meals with different amounts of dairy and calcium.

However, there are some limitations to the studies in this thesis. Firstly, we were not able to correct for the confounding effects of protein intake in the first epidemiological investigation. Although this was initially planned, we were not able to perform this correction because calcium and protein intake were highly correlated in the cohort we studied. In the second observational study, we performed a separate analysis of the effects of macronutrient intake on body composition, but the way the data had been collected in this study did not allow us to discern between different types of protein.

In the intervention trials discussed in chapters 4,5 and 7, we had based our power calculations on an effect that was larger than the observed effect of our interventions on the primary outcome measures, so this may have prevented us from finding statistically significant differences. Furthermore, it could be argued that the duration of the lowcalcium interventions was too short to induce differences in the metabolism of the subjects with a high habitual calcium intake. Finally, in the study in which we looked at the effects of calcium intake on faecal fat excretion, the relatively high protein content of the diets may have masked any effects of dietary calcium on fat absorption. However, we wanted to use these high protein diets in order to be able to compare the results to our previous studies.

Although the agonist we used in the microdialysis study has been shown to induce changes in the intracellular calcium concentration of rat fat cells and human muscle cells, we do not have conclusive evidence that it can also change the calcium concentration in human fat cells, although this is quite likely. Therefore, it cannot be ruled out that another mechanism caused the changes in lipolysis.

Finally, in the last intervention trial presented in this thesis, we were not able to discern between the effects of different components of dairy protein (i.e. whey and casein).

\section{General conclusions}

In short, the general conclusions from the investigations in this thesis are as follows:

-The association between calcium intake and body composition in The Netherlands is not as strong as in the US. Since we also observed a threshold for effects of calcium intake on body composition at around $800 \mathrm{mg} / \mathrm{day}$, this is probably due to the high habitual calcium intake in The Netherlands.

-Although we observed associations between macronutrient intakes with total energy intake, the intake of these macronutrients was not longitudinally associated with body composition.

-Although changes in serum calcitriol due to changes in calcium intake or due to supplementation with cholecalciferol are observed within a week, these changes do not affect energy and fat metabolism or adipose tissue mRNA expression of proteins related to fat metabolism.

-The results of our microdialysis study seem to indicate that the final step in the hypothesis of Zemel (decreasing intracellular calcium leads to increases in lipolysis) is present in vivo in humans. This would mean that although dairy intake affects calcitriol metabolism and although changes in intracellular calcium lead to changes lipolysis, 
changes in serum calcitriol do not lead to changes in intracellular calcium of adipocytes in vivo in humans.

-Furthermore, changes in calcium intake do not seem to induce statistically significant changes in faecal fat or energy excretion when the protein content of the diet is slightly above normal, which can be expected when a high dairy diet is consumed.

-Finally, changes in the postprandial plasma amino acid response of specific groups such as the BCAAs and the LNAAs and in the ratios of tryptophan and tyrosine to the total concentration of LNAAs that are caused by differences in dairy intake could cause differences in postprandial satiety, since we have observed that the ratios of tryptophan and tyrosine to the total LNAAs are correlated to the satiety hormones ghreline and CCK, respectively.

\section{Implications of these results}

The implications of these conclusions are that at the intake levels observed in the general population in The Netherlands, no major effects of increasing calcium or dairy intake on body composition are expected. However, in certain sub-populations with a low and possibly sub-optimal calcium or dairy intake, increasing the intake of dairy or calcium could have positive effects.

Furthermore, the investigation by Melanson et al. (12) showing that a high dairy intake increases fat oxidation during energy restriction and a number of studies showing beneficial effects of a high protein intake during energy restriction $(9,10,28)$ could mean that an adequate dairy intake has positive effects on weight loss during energy restriction. Since dairy products are commonly regarded as fattening, most people tend to exclude them from their diet while they are trying to lose weight. Therefore, it should be recommended to maintain an adequate low fat dairy intake, especially during weight loss.

\section{Directions for future research}

Future studies on the role of dairy intake on body composition should focus more on the metabolic effects of different components of dairy protein, such as BCAAs, leucine and the whey component of dairy protein, especially during periods of energy restriction. It could also be very interesting to study the effects of different types of protein (animal vs. vegetable vs. dairy) and different protein hydrolysates (whey vs. casein) on postprandial energy and fat metabolism and satiety responses. Furthermore, the effects of increasing dairy intake in sub-populations with an inadequate intake should be studied. 


\section{References}

1. Heaney RP. Normalizing calcium intake: projected population effects for body weight. J Nutr 2003;133:268S-270S.

2. Lin YC, Lyle RM, McCabe LD, McCabe GP, Weaver CM, Teegarden D. Dairy calcium is related to changes in body composition during a two-year exercise intervention in young women. $\mathrm{J}$ Am Coll Nutr 2000;19:754-60.

3. McCarron DA. Dietary calcium as an antihypertensive agent. Nutr Rev 1984;42:223-5.

4. Zemel MB, Shi H, Greer B, Dirienzo D, Zemel PC. Regulation of adiposity by dietary calcium. Faseb J 2000;14:1132-8.

5. Blaak EE, Saris WH. Substrate oxidation, obesity and exercise training. Best Pract Res Clin Endocrinol Metab 2002;16:667-78.

6. Schrauwen P. Determinants of energy and substrate metabolism. Maastricht: University of Maastricht, 1998.

7. Zo eet Nederland 1998. Resultaten van de Voedselconsumptiepeiling 1998. Den Haag: Van Marken Delft Drukkers, 1998.

8. Baba NH, Sawaya S, Torbay N, Habbal Z, Azar S, Hashim SA. High protein vs high carbohydrate hypoenergetic diet for the treatment of obese hyperinsulinemic subjects. Int J Obes Relat Metab Disord 1999;23:1202-6.

9. Skov AR, Toubro S, Ronn B, Holm L, Astrup A. Randomized trial on protein vs carbohydrate in ad libitum fat reduced diet for the treatment of obesity. Int J Obes Relat Metab Disord 1999;23:528-36.

10. Westerterp-Plantenga MS, Lejeune MP, Nijs I, van Ooijen M, Kovacs EM. High protein intake sustains weight maintenance after body weight loss in humans. Int J Obes Relat Metab Disord 2004;28:57-64.

11. Melanson EL, Sharp TA, Schneider J, Donahoo WT, Grunwald GK, Hill JO. Relation between calcium intake and fat oxidation in adult humans. Int J Obes Relat Metab Disord 2003;27:196-203.

12. Melanson EL, Donahoo WT, Dong F, Ida T, Zemel MB. Effect of low- and high-calcium dairy-based diets on macronutrient oxidation in humans. Obes Res 2005;13:2102-12.

13. Jacobsen R, Lorenzen JK, Toubro S, Krog-Mikkelsen I, Astrup A. Effect of short-term high dietary calcium intake on 24-h energy expenditure, fat oxidation, and faecal fat excretion. Int J Obes Relat Metab Disord 2005;29:292-301.

14. Shi H, Norman AW, Okamura WH, Sen A, Zemel MB. 1alpha,25-Dihydroxyvitamin D3 modulates human adipocyte metabolism via nongenomic action. Faseb J 2001;15:2751-3.

15. Xue B, Greenberg AG, Kraemer FB, Zemel MB. Mechanism of intracellular calcium $([\mathrm{Ca} 2+] \mathrm{i})$ inhibition of lipolysis in human adipocytes. Faseb J 2001;15:2527-9.

16. Xue B, Moustaid N, Wilkison WO, Zemel MB. The agouti gene product inhibits lipolysis in human adipocytes via a Ca2+-dependent mechanism. Faseb J 1998;12:1391-6.

17. Guerciolini R. Mode of action of orlistat. Int J Obes Relat Metab Disord 1997;21 Suppl 3:S12-23.

18. Govers MJ, Termont DS, Lapre JA, Kleibeuker JH, Vonk RJ, Van der Meer R. Calcium in milk products precipitates intestinal fatty acids and secondary bile acids and thus inhibits colonic cytotoxicity in humans. Cancer Res 1996;56:3270-5.

19. Welberg JW, Monkelbaan JF, de Vries EG, et al. Effects of supplemental dietary calcium on quantitative and qualitative faecal fat excretion in man. Ann Nutr Metab 1994;38:185-91.

20. Kerstetter JE, O'Brien KO, Insogna KL. Dietary protein affects intestinal calcium absorption. Am J Clin Nutr 1998;68:859-65.

21. Kerstetter JE, O'Brien KO, Insogna KL. Dietary protein, calcium metabolism, and skeletal homeostasis revisited. Am J Clin Nutr 2003;78:584S-592S.

22. Kerstetter JE, O'Brien KO, Insogna KL. Low protein intake: the impact on calcium and bone homeostasis in humans. J Nutr 2003;133:855S-861S.

23. Kerstetter JE, Svastisalee CM, Caseria DM, Mitnick ME, Insogna KL. A threshold for low-protein-dietinduced elevations in parathyroid hormone. Am J Clin Nutr 2000;72:168-73.

24. Schweiger U, Warnhoff M, Pahl J, Pirke KM. Effects of carbohydrate and protein meals on plasma large neutral amino acids, glucose, and insulin plasma levels of anorectic patients. Metabolism 1986;35:938-43.

25. Uhe AM, Szmukler GI, Collier GR, Hansky J, O'Dea K, Young GP. Potential regulators of feeding behavior in anorexia nervosa. Am J Clin Nutr 1992;55:28-32.

26. Manders RJ, Wagenmakers AJ, Koopman R, et al. Co-ingestion of a protein hydrolysate and amino acid mixture with carbohydrate improves plasma glucose disposal in patients with type 2 diabetes. Am J Clin Nutr 2005;82:76-83. 
27. van Loon LJ, Saris WH, Verhagen H, Wagenmakers AJ. Plasma insulin responses after ingestion of different amino acid or protein mixtures with carbohydrate. Am J Clin Nutr 2000;72:96-105.

28. Farnsworth E, Luscombe ND, Noakes M, Wittert G, Argyiou E, Clifton PM. Effect of a high-protein, energy-restricted diet on body composition, glycemic control, and lipid concentrations in overweight and obese hyperinsulinemic men and women. Am J Clin Nutr 2003;78:31-9. 


\section{Samenvatting}

Tijdens de laatste jaren heeft het probleem van obesitas zich uitgebreid van Noord Amerika naar Europa en andere delen van de wereld. Omdat obesitas geassocieerd is met andere chronische ziekten als diabetes en hart- en vaatziekten, zou dit gevolgen kunnen hebben voor de gezondheid en het welzijn van miljoenen mensen.

Het moge duidelijk zijn dat een positieve energiebalans (dus een energie-inname die groter is dan het energiegebruik) de belangrijkste factor is die een toename van lichaamsgewicht veroorzaakt. Daarom zijn voedingsmiddelen die deze balans kunnen herstellen door een verlaging van de energie-inname of een verhoging van het energiegebruik uitgebreid onderzocht. In de jaren tachtig zijn er voor het eerst indicaties gevonden van een negatief verband tussen calciuminname en lichaamsgewicht in epidemiologische studies die oorspronkelijk uitgevoerd waren om het verband tussen calciuminname en bloeddruk te onderzoeken. Het bleek dat mensen met een hoge calciuminname over het algemeen een lager lichaamsgewicht hadden. De groep van Zemel heeft de mogelijke cellulaire aspecten van deze relatie onderzocht in in vitro en dierstudies. Uit deze onderzoeken is de volgende hypothese afgeleid: Een toename van de calciuminname leidt tot een afname van de calcitriol concentratie in het serum. Deze afname zal leiden tot een afname van de instroom van calcium ionen de vetcellen in, wat zal leiden tot een toename van de lipolyse en een afname van de lipogenese. Verder zouden er ook effecten op het energiegebruik op kunnen treden, via directe effecten van calcitriol op de expressie van $U C P_{2}$, een eiwit dat mogelijk een correlatie heeft met het energiegebruik in rust. Bovenop deze effecten op energie- en vetmetabolisme, kunnen calcium en/of zuivelproducten ook gunstige effecten op lichaamssamenstelling hebben via andere mechanismen. Ten eerste zijn er aanwijzingen dat een hoge calciuminname zou kunnen leiden tot de vorming van niet-oplosbare vetzuur-zepen in de dunne darm, waardoor de hoeveelheid energie die geabsorbeerd kan worden uit het dieet afneemt. Ten tweede zouden bepaalde componenten van zuivel eiwit, zoals vertakte keten amino zuren (BCAAs), leucine en de wei fractie van zuivel eiwit positieve effecten kunnen hebben op het metabolisme na een maaltijd en op verzadiging. In dit proefschrift hebben we ons gericht op hoe een toename van de calciuminname een rol kan spelen bij het herstellen van de energiebalans via de bovengenoemde mechanismen.

In hoofdstuk 2 hebben we de longitudinale associaties tussen calciuminname en lichaamssamenstelling in een cohort van gezonde, jonge Nederlandse mannen en vrouwen besproken. De proefpersonen in dit cohort werden gevolgd in de leeftijd van 13 tot 36 jaar en tijdens deze periode werden diverse metingen van lichaamssamenstelling, leef- en eetgewoontes uitgevoerd. De gegevens uit dit cohort werden geanalyseerd met de GEE methode. Met deze analyse konden we de longitudinale associatie tussen calciuminname en lichaamssamenstelling bestuderen. We zagen een klein effect van calciuminname op lichaamssamenstelling, dat erop neerkwam dat mannen met een $1000 \mathrm{mg}$ hogere calciuminname een $0.21 \mathrm{~cm}$ lagere som van de vier huidplooien hadden gedurende de 23 -jarige meetperiode.

Maar de effecten van calciuminname op de lichaamssamenstelling verdwenen na correctie voor mogelijke verstorende cofactoren zoals lichamelijke activiteit, dus het effect was minder sterk dan eerdere resultaten uit de VS. Een mogelijke verklaring hiervoor komt uit hetzelfde onderzoek, omdat we ook een drempelwaarde voor de 
effecten van calciuminname op lichaamssamenstelling bij een inname van ongeveer 800 mg per dag hebben gevonden, terwijl de gemiddelde inname van de proefpersonen meer dan $1000 \mathrm{mg}$ per dag bedroeg. Tenslotte had calciuminname ook een lage tracking coëfficiënt, wat betekent dat de calciuminname bij de eerdere metingen geen voorspellende waarde had voor de calciuminname bij de latere metingen.

Het is waarschijnlijk dat mensen met een hoge zuivelinname ook een relatief hoge eiwitinname hebben. Van eiwit is aangetoond dat het een aantal effecten op de stofwisseling heeft, zoals een verhoogde thermogenese, een verhoogde verzadiging en een kleiner verlies van vetvrije massa tijdens energierestrictie, waardoor een hoge eiwitinname gunstige effecten op het lichaamsgewicht zou kunnen hebben. Daarom wilden we voor de verstorende effecten van eiwitinname corrigeren in de studie waarbij we keken naar de longitudinale associatie tussen calciuminname en lichaamssamenstelling. Maar omdat dit niet mogelijk was vanwege de hoge correlatie tussen eiwit en zuivelinname in deze populatie, hebben we een aparte analyse uitgevoerd die is beschreven in hoofdstuk 3. Het ontwerp van deze studie was ruwweg hetzelfde als de studie uit het vorige hoofdstuk; we gebruikten data uit hetzelfde cohort en gebruikten dezelfde longitudinale manier om de data te analyseren. We zagen een positieve relatie tussen veranderingen in vetinname en totale energie-inname en een negatieve relatie tussen veranderingen in eiwitinname en totale energie-inname in deze studie bij mannen en vrouwen en een negatief verband tussen koolhydraatinname en energie-inname bij mannen. Deze verbanden bevestigden dat er een longitudinaal verband bestaat tussen de energiedichtheid van het dieet en de energie-inname. Daarentegen was er geen verband tussen deze verschillen in de inname van macronutriënten en lichaamssamenstelling. In tegenstelling tot het negatieve longitudinale verband tussen eiwit- en energie-inname hadden proefpersonen met een hoog vetpercentage ( $>25 \%$ voor mannen en $>35 \%$ voor vrouwen) bij de laatste meting ook een hogere eiwitinname bij de laatste metingen. Deze tegenstrijdige resultaten zouden verklaard kunnen worden doordat er verschillende methodes werden gebruikt om het vetpercentage te meten (huidplooimetingen tegenover DEXA bij de laatste metingen) en doordat er verschillende statistische methodes gebruikt werden (continu tegenover categorisch). Dus uit deze tweede epidemiologische studie concludeerden we dat er geen sterke longitudinale verbanden zijn tussen macronutriënt inname en lichaamssamenstelling. Het onverwachte positieve verband tussen eiwitinname en lichaamssamenstelling zou verklaard kunnen worden doordat we geen onderscheid konden maken tussen verschillende bronnen van eiwit (zoals dierlijk, zuivel en plantaardig eiwit).

Om te onderzoeken of verschillen in calcium- en zuivelinname verschillen in energiegebruik en vetverbranding kunnen bewerkstelligen door veranderingen in de serum calcitriol concentratie, hebben we een dieetinterventie studie uitgevoerd bij twaalf jonge mannen met een normaal lichaamsgewicht. Deze studie is beschreven in hoofdstuk 4. In dit hoofdstuk beschrijven we de effecten van drie diëten met verschillende calciumgehaltes op het energie- en vetgebruik in rust, gemeten in een respiratiekamer en op de mRNA expressie in vetweefsel. We zagen significante verschillen in de serum calcitriol concentratie, dus een dieet rijk aan zuivel en calcium verlaagde de serum calcitriol concentratie en een dieet arm aan zuivel en calcium verhoogde de serum calcitriol concentratie, wat past in de hypothese van Zemel. Daarentegen zagen we geen significante effecten op het energie- en vetmetabolisme, hoewel de 24 uurs vetoxidatie ongeveer 8 gram per dag hoger was bij de hoog calcium en zuivel interventie in vergelijking met de laag calcium en zuivel interventie. Verder 
zagen we ook geen effecten van de diëten op de mRNA expressie van een aantal genen die gerelateerd zouden kunnen zijn aan vetopslag en -afbraak.

Daarom wilden we de effecten van veranderingen in de serum calcitriol concentratie op energie- en vetmetabolisme in dezelfde populatie verder bestuderen. Om de bloedspiegels van calcitriol te manipuleren kregen de proefpersonen een oraal cholecalciferol supplement en moesten ze een dieet consumeren met een laag gehalte aan calcium, zuivel en vitamine D. Energie-, vetmetabolisme en de mRNA expressie in vetweefsel werden gemeten en zijn besproken in hoofdstuk 5 . We vonden alweer geen significante verschillen in energie en vetmetabolisme of mRNA expressie in vetweefsel, ondanks een significante toename van de serum calcitriol na 5 en 7 dagen van de interventie. De toename in de serum calcitriol concentratie in deze studie was vergelijkbaar met de verschillen die we zagen in de dieetinterventie studie uit hoofdstuk 4.

Nadat we in de eerste twee klinische studies gezien hadden dat veranderingen in de serum calcitriol concentratie niet de verwachte metabole effecten veroorzaken, besloten we de laatste stap in de hypothese van Zemel (dus dat een afname van de intracellulaire calciumconcentratie in vetcellen leidt tot een toename van de lipolyse) meer in detail te bestuderen. Om te onderzoeken of veranderingen in de intracellulaire calciumconcentratie in vetcellen inderdaad kunnen leiden tot veranderingen in in vivo lipolyse, hebben we de microdialyse studie uitgevoerd die beschreven is in hoofdstuk 6 . In dit experiment hebben we de effecten van hydralazine op lipolyse in het vetweefsel in de buikregio van gezonde mannen zonder overgewicht bekeken. We zagen dat perfusie van onderhuids vetweefsel met toenemende concentraties van hydralazine, een medicijn tegen hoge bloeddruk met effecten op de intracellulaire calcium concentratie, leidt tot een toename van de interstitiële glycerol concentratie. Uit dit experiment kregen we dus indicaties dat een afname van de intracellulaire calciumconcentratie in vetcellen kan leiden tot een toename in lipolyse in deze cellen in mensen.

Omdat er aanwijzingen waren dat een hoge calciuminname kan leiden tot een verminderde vetabsorptie uit het maagdarmkanaal via de vorming van onoplosbare vetzuur-zeep complexen in het lumen van de dunne darm, hebben we een extra experiment uitgevoerd, dat beschreven staat in hoofdstuk 7. In deze klinische interventie studie, hebben we vier diëten met een verschillende hoeveelheid calcium en zuivel gegeven aan 10 gezonde mannen en vrouwen met een normaal lichaamsgewicht. We hebben metingen aan energie- en vetmetabolisme, faecale vet- en energie-uitscheiding, mRNA expressie in vetweefsel en verschillende bloedparameters uitgevoerd. We zagen weliswaar een mogelijke trend van het verhogen van de calciuminname op vetabsorptie maar geen significante verschillen, hoewel de absolute waarden van faecale vetexcretie en faecale energie-excretie vergelijkbaar waren met die in eerdere studies. De vetexcretie was ongeveer 6 gram per dag en de totale energie-excretie was rond $600 \mathrm{~kJ}$ per dag. De verschillen tussen de diëten met de laagste en de hoogste calcium concentratie waren $71 \mathrm{~kJ} / \mathrm{dag}$ en $2.7 \mathrm{~g} / \mathrm{dag}$ voor energie- en vetexcretie, respectievelijk. Het uitblijven van significante effecten zou veroorzaakt kunnen zijn door het hoge eiwitgehalte van de diëten, omdat van eiwit is aangetoond dat het de absorptie van calcium uit de dunne darm zou kunnen verhogen, waardoor er minder calcium beschikbaar komt voor de binding aan vet. Dit zou kloppen met de resultaten van eerdere studies waarbij de effecten van calcium- en zuivelinname op faecale vetexcretie onderzocht zijn en waarbij ook geen effecten gezien werden wanneer de diëten een hoog gehalte aan eiwit hadden. Net zoals bij onze eerdere studies, werden het energieen vetmetabolisme ook niet beïnvloed door de calciumconcentratie van het dieet. Maar 
we zagen wel een significante verlaging van de mRNA expressie van het enzym fatty acid synthase door het dieet met de hoogste calciumconcentratie. Verder verminderde een hoge calcium inname ook de plasma concentratie van triglyceriden. Uit deze studie concludeerden we dat er enkele aanwijzingen zijn dat calcium vetabsorptie en vervolgens vetmetabolisme kan beïnvloeden, maar deze verschillen waren klein en niet statistisch significant.

Tenslotte presenteerden we in hoofdstuk 8 de effecten van verschillen in postprandiale aminozuur profielen op markers van verzadiging. Eerdere onderzoeken hebben uitgewezen dat een hoge inname van calcium en/of zuivel eiwit een hogere mate van verzadiging en een vermindering van de totale voedselinname bij een volgende maaltijd zouden kunnen bewerkstelligen. Om dit te onderzoeken, hebben we de postprandiale effecten van twee maaltijden met verschillende eiwitbronnen bestudeerd in een gerandomiseerde studie. Deze studie is uitgevoerd in samenwerking met de KVAU in Kopenhagen als een onderdeel van een groter onderzoek naar de effecten van maaltijden met een verschillende hoeveelheid zuivel en calcium op het vetmetabolisme na een maaltijd. De studie is uitgevoerd bij 18 gezonde mannen met overgewicht. We zagen weliswaar verschillen in de postprandiale aminozuur respons van twee groepen aminozuren (de grote neutrale aminozuren (LNAAs) en de korte keten vertakte aminozuren (BCAAs)), tussen de maaltijd met een hoog gehalte aan zuiveleiwit en de maaltijd met soja als belangrijkste bron van eiwit, maar we zagen geen verschillen in diverse markers van verzadiging. Daarentegen zagen we wel enkele significante relaties tussen dezelfde aminozuurgroepen (de LNAAs en BCAAs) en de verzadigingshormonen ghreline en cholecystokinine (CCK). We vonden een significant positief verband tussen de respons van de TRP/LNAA-ratio en de plasma ghreline repons. Er zijn aanwijzingen dat deze ratio gerelateerd is aan de beschikbaarheid van tryptofaan voor de hersenen. Dit zou de vorming van serotonine kunnen beïnvloeden, een neurotransmitter die een rol speelt bij verzadiging. Verder was het ook zo dat de respons van de TYR/LNAA-ratio positief gecorreleerd was met de plasma CCK respons. Tyrosine is noodzakelijk voor de vorming van noradrenaline, een andere neurotransmitter die een rol speelt bij verzadiging en net als bij de TRP/LNAA-ratio zou een verandering in deze ratio kunnen betekenen dat de beschikbaarheid van dit aminozuur voor de hersenen verandert. Deze waarnemingen zouden kunnen betekenen dat een hoge zuivelinname de verzadiging na een maaltijd beïnvloedt via veranderingen in de plasma aminozuur respons. 


\section{Summary}

During the past decades, the pandemic of obesity has expanded from North America to Europe and other parts of the world. Because obesity is associated with other chronic diseases such as diabetes and cardiovascular diseases, this means the overall health and well being of millions of people could be affected.

Obviously, a positive energy balance (i.e. an energy intake that is higher than energy expenditure) is the main factor driving increases in body weight. Therefore, foods that can restore this energy balance either by increasing energy expenditure or by decreasing food intake have been investigated extensively. During the 1980s, indications of a negative association between calcium intake and body weight were seen in epidemiological studies that were originally designed to study the relation between calcium intake and blood pressure. It was observed that subjects with a high calcium intake generally had a lower body weight. The group of Zemel explored the possible cellular aspects of this relation in animal and in vitro studies. From this research, the following hypothesis was deducted: Increases in dietary calcium intake decrease the serum calcitriol concentration. This decreased calcitriol concentration will in turn decrease the influx of calcium into adipocytes, which leads to an increase in lipolysis and a decrease in lipogenesis. Furthermore, energy expenditure might also be affected, through direct effects of calcitriol on the expression of $U_{C P}$, a protein that has been shown to be correlated with the basal metabolic rate. In addition to these effects on energy and fat metabolism, calcium and/or dairy products could also have beneficial effects on body composition through other mechanisms. Firstly, it has been observed that a high calcium intake could lead to the formation of insoluble fatty acid soaps in the intestine, which would decrease the amount of energy that can be absorbed from the diet. Secondly, certain components of dairy protein, such as BCAAs, leucine and the whey fraction of protein could have beneficial effects on postprandial metabolism and satiety. In this thesis, we have focused on how an increased calcium intake can play a role in restoring this energy balance through all of these mechanisms.

In chapter 2, we discussed the longitudinal associations between calcium and body composition in a cohort of healthy, young Dutch men and women. The subjects in this cohort were studied between the ages of 13 and 36 and during this period, various measurements of body composition, lifestyle and dietary habits were performed. The data from this cohort were analyzed with the GEE analysis. This type of analysis allowed us to study the longitudinal relation between calcium intake and body composition. Although we observed a slight effect of calcium intake on body composition, implicating that men with a $1000 \mathrm{mg}$ higher dietary calcium intake had a $0.21 \mathrm{~cm}$ lower sum of 4 skinfolds throughout the 23 years of measurements. However, the effects of calcium intake on body composition disappeared after adjustment for possible confounders such as physical activity, so the effect was not as strong as the results previously observed in the US. A possible explanation for this lack of effect comes from the same investigation, since we also observed a threshold for the effects of calcium intake on body composition at around $800 \mathrm{mg}$ per day, whereas the average intake of the subjects was more than $1000 \mathrm{mg}$ per day. Finally, calcium intake had a low tracking coefficient, which means that calcium intake at the earlier measurements was not predictive of calcium intake at the later measurements. 
It is likely that people with a high dairy calcium intake also have a relatively high protein intake. Protein has been shown to have a number of effects, such as an increased thermogenesis, an increased satiety and a decreased loss of lean mass during energy restriction, through which a high protein intake could affect body weight. Therefore we wanted to correct for the confounding effects of protein intake in the study in which we investigated the longitudinal association between calcium intake and body composition. But because this was not possible due to the high correlation between protein and dairy intake in our study population, we performed a separate study that is described in chapter 3 . The design of this study was roughly the same as the design of the study described in the previous chapter, i.e. data from the same cohort were used and we used the same type of longitudinal data analysis. We observed a positive relation between changes in fat intake and total energy intake and a negative relation between changes in protein intake and total energy intake in this study in men and women and a negative association between carbohydrate intake and energy intake in men. These associations confirmed that the energy density of the diet indeed has a longitudinal association with the total energy intake. However, these differences in macronutrient intake were not associated with body composition. In contrast to the negative longitudinal association between protein intake and energy intake, subjects with a high body fat \% (i.e. $>25 \%$ for men and $>35 \%$ for women) at the last measurement, also had a higher protein intake at the last measurements. This discrepancy in results might be explained by the differences in the methods that were used to measure body composition (skinfolds vs. DEXA at the last measurements) and differences in the type of statistical methods (ordinal vs. categorical) between these two analyses. So from this second observational study, we concluded that there are no strong associations between macronutrient intake and body composition. The unexpected positive relation between protein intake and body composition might be explained by the fact that we were not able discern between different sources of protein (i.e. animal, dairy and/or vegetable protein).

In order to study if changes in calcium and dairy intake can indeed induce changes in energy expenditure and fat oxidation via changes in the serum calcitriol concentration, we have performed a dietary intervention study in twelve healthy, young men with a normal body weight. This study is described in chapter 4 . In this chapter, the effects of 3 diets with various calcium contents on resting energy and fat metabolism as measured in a metabolic chamber and adipose tissue mRNA expression are presented. We observed significant changes in the serum calcitriol concentration, i.e. the high calcium high dairy diet significantly decreased the serum calcitriol concentration and the low calcium low dairy diet significantly increased the serum calcitriol concentration, which is in line with the hypothesis of Zemel. However, no significant effects on energy and fat metabolism were observed, although the 24 hour fat oxidation was approximately 8 grams per day higher on the high calcium high dairy intervention compared to a low calcium low dairy diet. Furthermore, we also did not observe any effects of the dietary interventions on the mRNA expression of a number of genes that could be related to lipogenesis or lipolysis. Reason to investigate the effects of changes in the serum calcitriol concentration on energy and fat metabolism in the same study population in more detail. To manipulate the blood levels of calcitriol subjects were supplemented with cholecalciferol and they were instructed to consume a diet with a low content of calcium, dairy and vitamin D. Energy and fat metabolism and adipose tissue mRNA expression were measured, and discussed in chapter 5 . Once again, we did not observe any significant differences in energy, fat metabolism nor adipose tissue mRNA expression, despite a significant increase in serum calcitriol after 5 and 7 days of the supplementation regime. The 
increases in serum calcitriol in this investigation were in line with the changes we observed in the dietary intervention trial that was presented in chapter 4 .

After we had observed in our first two clinical trials that changes in the serum calcitriol concentration do not induce the expected metabolic effects, we decided to study the last step in the hypothesis of Zemel (i.e. a decrease in intracellular calcium in adipocytes leads to an increase in lipolysis) in more detail. To investigate if changes in intracellular calcium in fat cells can indeed lead to changes in lipolysis in humans in vivo, we performed the microdialysis study that is described in chapter 6 . In this experiment, we studied the effects of hydralazine on lipolysis in abdominal fat tissue of healthy nonobese men. We observed that perfusion of subcutaneous adipose tissue with increasing concentrations of hydralazine, an anti-hypertensive with well-known effects on intracellular calcium, lead to increases in the interstitial glycerol concentration. From this experiment, we obtained indications that a decrease in intracellular calcium in fat cells can lead to increases in lipolysis in these cells in humans.

Because there were indications that a high calcium intake can lead to a decreased fat absorption from the gut through the formation of insoluble fatty acid soaps in the lumen of the intestine, we carried out an additional experiment that is discussed in chapter 7 . In this clinical intervention trial, we administered four diets with a different calcium concentration and a different amount of dairy to 10 healthy men and women with a normal body weight. Measurements of energy and fat metabolism, faecal fat and energy excretion, mRNA expression in fat tissue and various blood parameters were carried out. Although we observed a trend towards effects of increasing dietary calcium intake on fat absorption this failed to reach statistical significance, although the absolute values of the faecal fat excretion and total faecal energy excretion were in line with previous studies. Fat excretion was around 6 grams per day and the faecal energy excretion was around $600 \mathrm{~kJ}$ per day. The differences between the diets with the lowest and the highest calcium concentration were $71 \mathrm{~kJ} /$ day and $2.7 \mathrm{~g}$ /day for energy and fat excretion, respectively. The absence of any significant effects may have been caused by the high protein content of the diets, because protein has been shown to increase the intestinal absorption of calcium, thus making less calcium available for binding to fat. This would be in line with previous investigations in which the effects of calcium and dairy intake on faecal fat excretion were studied and where no effects were observed too when the diet had high protein content. In line with our previous investigations, energy and fat metabolism were also not affected by the calcium content of the diet. However, we did observe a significant decrease in the mRNA expression of the enzyme fatty acid synthase in response to the diet with the highest calcium concentration. Furthermore, a high calcium intake also decreased the plasma concentration of triglycerides. From this study, we concluded that there are some indications that calcium can affect fat absorption and consequently fat metabolism, but these effects are small and not statistically significant.

Finally, in chapter 8 , the effects of differences in the postprandial plasma amino acid profiles on markers of satiety are presented. Previous investigations indicate that a high intake of calcium and/or dairy protein could induce a higher grade of satiety and reduce the total food intake at a consequent meal. To investigate this, the postprandial effects of 2 meals with different sources of protein were tested in a randomized crossover design. This study was performed together with the KVAU in Copenhagen as part of a larger study on the effects of meals with a different amount of dairy and calcium on postprandial lipid metabolism. This study was carried out in a group of 18 overweight but otherwise healthy men. Although we observed differences in the postprandial 
plasma amino acid responses of two groups of amino acids (large neutral amino acids (LNAAs) and branched chain amino acids (BCAAs)), between the dairy meal and the meal with soy as the main source of protein, we did not observe any differences in markers of satiety. However, we did observe some significant correlations between these same groups of amino acids (LNAAs and BCAAs) and the satiety hormones ghrelin and cholecystokinine (CCK). We found a significant positive correlation between the response of the TRP/LNAA-ratio and the plasma ghrelin response. It has been suggested that a change in this ratio could result in a changed availability of tryptophan to the brain. This could alter the formation of serotonin, a neurotransmitter, which plays a role in satiety. In line with this finding, we also observed that the response of the TYR/LNAA-ratio was positively correlated with the plasma CCK response. Tyrosine is necessary for the formation of noradrenaline, another neurotransmitter that could play a role in satiety and like the TRP/LNAA-ratio; changes in this ratio may indicate a changed availability of this amino acid to the brain. These observations could implicate that a high dairy intake affects postprandial satiety through changes in the plasma amino acid response. 
Dit dankwoord voelt een beetje alsof ik de laatste kilometers in ga terwijl de buit al binnen is. Dus dan haal je nog maar eens diep adem, je trekt je shirt recht, je veegt je gezicht schoon, controleert of je helm recht zit en je verder enigszins toonbaar bent. Vervolgens geef je jezelf een schouderklopje en geniet je van het moment...

Allereerst wil ik alle proefpersonen die bij mijn onderzoeken meegewerkt hebben ontzettend bedanken. Een goede analogie met de koers kan ik even niet maken maar zonder jullie was er weinig van mijn onderzoeken terecht gekomen en ik besef me terdege dat de testen waaraan ik jullie heb onderworpen lang niet altijd leuk en gemakkelijk waren. Bovendien was het gewoon erg leuk om met jullie te werken en dat maakte het een stuk makkelijker om 's ochtends om half 7 al gezellig en leuk te zijn.

Wim, zonder een goede ploegleider is een renner natuurlijk helemaal nergens. Ik wil je bij deze ontzettend bedanken voor de erg plezierige samenwerking van de afgelopen jaren. Je directe manier van communiceren en de grote mate van vrijheid en zelfstandigheid die je me toevertrouwde waren voor mij de perfecte ingrediënten voor vier succesvolle jaren.

Verder wil ik de wedstrijdjury oftewel de beoordelingscommissie graag hartelijk bedanken. Ad, Roelof, Jan, Margriet en Ronald dank voor de kritische evaluatie van mijn proefschrift, de kwaliteit ervan is zeker omhoog gegaan dankzij jullie opmerkingen.

Een coureur is nergens zonder goede ondersteuning van ploegdokters, mecanichiens en verzorgers. En ik moet zeggen dat we daar wel een paar uitzonderlijk goede voorbeelden van rond hebben lopen bij Humane Biologie. Hierbij even een opsomming: Gabby en Marco, jullie hebben aardig wat vetbiopten en bloedmonsters voor me afgenomen, meestal op onmenselijke tijdstippen. Bedankt dat jullie altijd vroeg je bed uit wilden komen voor me, al dan niet onder zachte dwang. Jos je bent een geweldige

134 vent, je chagrijnigheid is onnavolgbaar grappig en HB zou instorten zonder jou. Ik hoop dat ik de eerste en de laatste was die je lastig kwam vallen met blauw/witte bakjes met onbestemde inhoud. Wendy, heel erg bedankt voor je opgewektheid en hulp bij alle analyses. Joan, of het nou ging over een ijklijn die ik weer eens verknoeid had of de koersen van het afgelopen weekend, bij jou kon ik altijd aankloppen voor een goed gesprek met de nodige diepgang. Loek, ik kan me goed voorstellen dat je regelmatig genoeg van mijn vragen over passwords en bomcalorimeters gekregen hebt, en bij deze bedankt voor al je hulp. Paul, dankzij jou zit ik nu achter een mooie witte iBook en niet achter een gammele Windows machine. Verder kan je het zo gek niet bedenken of jij snapt hoe het in elkaar zit en hoe het werkt. En vaak kan je het ook nog eens zelf bouwen. Respect.

Dan is er nog een enorm peleton HB'ers, veel te groot om allemaal te gaan noemen. Hierbij dus ook een selectie. Ralph, kamergenoot door dik en dun, je muzieksmaak en behulpzaamheid staan op een eenzaam hoog niveau. Succes met het afronden van je promotie. Een bijzondere vermelding in deze categorie verdienen Alie en Mandy, niet alleen omdat het gewoon leuk was om een kamer met jullie te delen maar ook omdat jullie altijd braaf om mijn fietsen heen gelopen zijn en ze niet verkocht hebben aan de schoonmakers als ik even niet keek. René, samen bankdrukken of fietsen is al een tijdje geen plan meer, maar als ik nog eens in Maastricht ben moeten we maar eens hapje of een drankje gaan doen. Luc, jij bent degene waardoor ik ontdekte hoe leuk het is om wetenschappelijk onderzoek te doen en ik ben daarna ook niemand meer tegengekomen die zijn experimenten met hetzelfde fanatisme en perfectionisme uitvoert. Let wel een beetje op jezelf. Patrick en Matthijs, bedankt voor de kans die jullie me hebben gegeven om als student-assistent van de wetenschap te proeven (en een jaartje flink te trainen). 
Gijs, ik heb een aantal keer met je samen mogen werken en ik denk dat je het nog ver zal schoppen als wetenschapper. Verder wil ik ook Anne, Annemiek, Claudia, Elke, Freddy, Johan J, Johan de V, Joost, Joris, Klien, Kristof, Larisa, Lydia, Mariëlle en Petra hartelijk bedanken. Jullie hebben er zeker toe bijgedragen dat ik vier leuke jaren heb gehad in Maastricht.

Verder heb ik in de loop van de tijd ook her en der wat combines gesmeed. Lando en Willem, het was erg fijn om met jullie samen te werken en veel succes verder met het AGGO. Ellen, bij het opzetten en uitvoeren van onze microdialyse studie zijn we aardig wat obstakels tegengekomen, maar dat stond een hele prettige samenwerking niet in de weg. Audrey, Carine, Dominique et Nathalie, merci beaucoup pour votre très agréable coopération. J'ai beaucoup apprécié travailler avec vous pendant ces quelques semaines. Dr Ivy, John, I had a great time in Austin, it was an awesome exprerience and I think back about it quite often. Thanks a lot for giving me the opportunity to work in your lab. Ook de renners van mijn nieuwe ploeg, Unilever, wil ik hier toch maar even vermelden. Ik voelde me meteen thuis bij jullie en verheug me op de komende tijd.

Hoewel ik natuurlijk niet voor niets een mountainbiker ben (als ik echt van gezelligheid had gehouden was ik wel gaan voetballen of een ander bierspelletje gaan doen) is het erg fijn om een paar vrienden te hebben waar je altijd terecht kan: Caroline, Jacomine, Judith, Marcel en Roel, bedankt voor alles.

Dan is er nog familie, zeg maar een soort 'hors categorie'. Eerst mijn zusjes/zussen: Hanneke je komt er wel. Een hoop mensen zouden een voorbeeld kunnen nemen aan je vechtlust en perfectionisme. Je bent een bewonderenswaardige en bijzondere meid en ik ben er trots op dat ik me je broer mag noemen. En als je zo door gaat kom je zeker wel waar je uit wilt komen, dat weet ik zeker. Eva, hoewel Canada-Berkel en Rodenrijs iets verder is dan Groningen-Maastricht is afstand relatief. Ik bedoel, we hadden ook allebei in een ander parallel universum kunnen zitten, dat was pas ver weg geweest. Verder heel veel plezier met je schimmels. En als het mis gaat: 'Blame Canada!!'.

Ria en Leen, ouders, hoewel ik meestal in mijn eigen stijl uitlegde waar ik mee bezig was, en die stijl is soms op zijn zachtst gezegd vrij bondig, bleven jullie toch steeds geïnteresseerd in mijn onderzoek. En dat zegt genoeg over jullie. Heel erg bedankt dat jullie me kans geven om te doen wat ik doe. 


\section{Papers}

Boon N, Hul GB, Viguerie N, Sicard A, Langin D, Saris WH. Effects of 3 diets with various calcium contents on 24-h energy expenditure, fat oxidation, and adipose tissue message RNA expression of lipid metabolism-related proteins. Am J Clin Nutr 2005;82:1244-52.

Boon N, Hul GBJ, Sicard A, et al. The effects of increasing serum calcitriol on energy and fat metabolism. Obes Res 2006;14:1739-46.

Boon N, Koppes LL, Saris WH, Van Mechelen W. The Relation between Calcium Intake and Body Composition in a Dutch Population: The Amsterdam Growth and Health Longitudinal Study. Am J Epidemiol 2005;162:27-32.

\section{Abstracts}

N. Boon, G.B.J. Hul, N. Viguerie, A. Sicard, D Langin, W.H.M. Saris. The effects of three diets with varying calcium contents on 24-hour energy-expenditure, 24-hour fat oxidation and adipose tissue mRNA expression. European congress of obesity, Athens 2005.

N. Boon, L.L.J. Koppes, W.H.M. Saris, W. Van Mechelen. The relation between calcium intake and body composition in a Dutch population: The Amsterdam Growth and Health Longitudinal Study (AGAHLS). European congress of obesity, Athens 2005.

N.Boon, G.B.J.Hul, N.Viguerie, A.Sicard, D.Langin, W.H.M.Saris. The effects of dietary calcium and oral cholecalciferol supplementation on adipose tissue mRNA expression. NUGO annual meeting, Italy 2005. 
Niels Boon was born on May 30th 1979 in Rotterdam, The Netherlands. He completed secondary school at the Erasmiaans Gymnasium in Rotterdam in 1997. In the same year, he started his study in Health Sciences with a specialization in Movement Sciences at the University of Maastricht. In the third year of his study, he worked as an assistent at the departement of Human Biology. In 2001, he started his first internship at the University of Texas at Austin, in the lab of Dr John L Ivy, participating in research about the effects of different carbohydrate/protein drinks on exercise performance and hormonal reponses during subsequent bouts of exercise. After obtaining his MSc, he did a second internship at the University of Maastricht, under the supervision of Prof Dr Ir Wim HM Saris, about the effects of amino acid ingestion on plasma glucose and insuline response and exercise performance. In December 2002, he started his PhD, described in this thesis, at the Department of Human Biology, at the University of Maastricht. This research was funded by the Dutch Dairy Association and was performed under the supervision of Prof Dr Ir Wim HM Saris. Niels is currently working as a research scientist at the Unilever Food and Health Research Institute in Vlaardingen. 